Historical Document Released for Public Availability.

\title{
Hanford Production Reactor Heat Releases 1951-1971
}

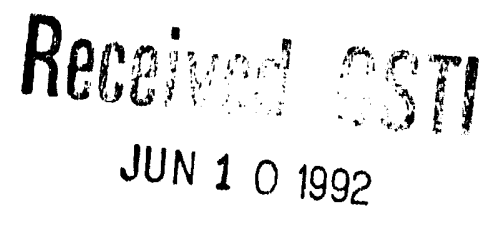

L. D. Kannberg

April 1992

Prepared for the U.S. Department of Energy under Contract DE-AC06-76RLO 1830

Pacific Northwest Laboratory

Operated for the U.S. Department of Energy

by Battelle Memorial Institute

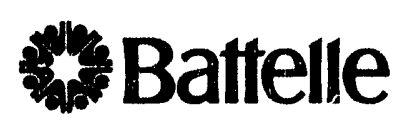




\title{
DISCLAIMER
}

This report was prepared as an account of work sponsored by an agency of the United States Government. Neither the United States Government nor any agency thereof, nor Battelle Memorial Institute, nor any of their employees, makes any warranty, expressed or implied, or assumes any legal liability or resporsibility for the accuracy, completeness, or usefulness of any information, apparatus, product, or process disclosed, or represents that its use would not infringe privately owned rights. Reference herein to any specific commercial product, process, or service by trade name, trademark, manufacturer, or otherwise does not necessarily constitute or imply its endorsement, recommendation, or favoring by the United States Government or any agency thereof, or Battelle Memorial Institute. The views and opinions of authors expressed herein do not necessarily state or reflect those of the United States Government or any agency thereof.

\author{
PACIFIC NORTHWEST LABORATORY \\ operated by \\ BATTELLE MEMORIAL INSTITUTE \\ for the \\ UNITED STATES DEPARTMENT OF ENERCY \\ under Contract DE-AC06-76RLO 1830
}

Printed in the United States of Anterica

Available to DOE and DOE contractors from the

Office of Scientific and Technical Information, P.O. Box 62, Oak Ridge, IN 37831; prices available from (615) 576-8401. FTS 626-8401.

Available to the public from If National Technical Information Service, U.S. Department of Commerce, 5285 Port Royal Rd., Springfield, VA 22161. 
L. D. Kannberg

August 1978 (date of work) Apri1 1992

Work supported by

the U.S. Department of Energy

under Contract EY-76-C-06-1830

Pacific Northwest Laboratcry Richland, Washington 99352

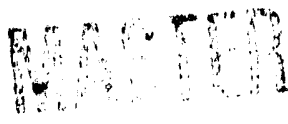




\section{SUMMARY}

Beginning in 1944 , nine nuclear materials production reactors were constructed and operated on the Hanford Reservation. Eight of the reactors operated from 1955 through 1964; nine operated most of 1964. Operating reactor levels grew throughout the period reaching highest levels in the middle 1960's. Maximum average reactor power reached 23,501 $\mathrm{MW}_{t}$ in December of 1964. For 13 of 15 months maximum average power levels exceeded $20,000 \mathrm{MW}_{t}$. For over 8 years maximum average power levels exceeded $15,000 \mathrm{MW}_{t}$. Only one reactor now remains in operation.

All of the thermal energy produced in the reactors was released to the environment; 90 to $97 \%$ of that energy entered the Columbia River directly. The remaining 3 to $10 \%$ was transferred from retention basins to the atmosphere or ground water by surface heat transfer and leakage, respectively. The reactors operated with direct once-through cooling with effluents being discharged primarily at 70 to $90^{\circ} \mathrm{C}$.

Numerous studies have been performed investigating the mixing characteristics of the effluent plumes. These studies have shown that the effluents mix rapidly vertically but slowiy laterally until major topographic features in the river force extensive mixing by wakes and secondary flcws. Flow management by dams also appears to have a significant influence on Columbia River thermal dynarics.

Studies on the persistence of the Hanford thermal discharges have indicated that the free flowing reach near the Hanford discharges experiences much more sur'ace heat transfer than impounded waters either upstream or downstream of the Hanford reach. As a result, the bulk of the thermal additions introduced by the production reactors was dissipated before effluents reached the washington-Oregon border.

Extensive study of the Hanford ecosystem and anadramous fish migrating through, to, and spawning in the Hanford reach has detailed the effects of thermal exposures on the local ecosystem and on salmonid fish. The general conclusion is that Hanford thermal discharges caused no detectable harm to the aquatic ecology nor did they injure in any measurable manner the salmon 
or trout fisheries. However, dam effects on the aquatic ecology of the river, especially salmon and trout fisheries, may have masked Hanford thermal effects within natural variation. 


\section{CONTENTS}

SUMMARY

INTROOUCTION.

DESCRIPTION OF THE REACTOR COOLING SYSTEMS. . . . . . . . . . . . . . . . 4

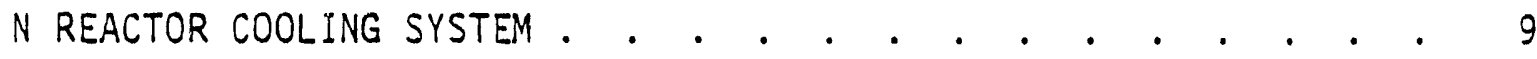

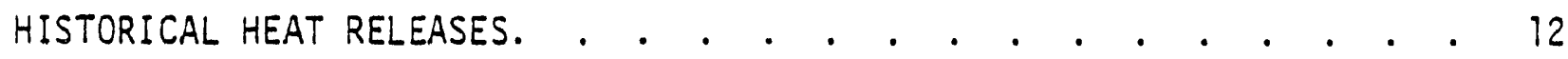

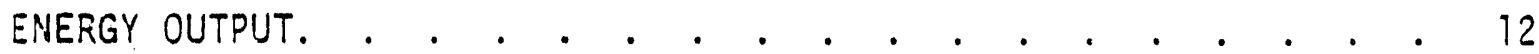

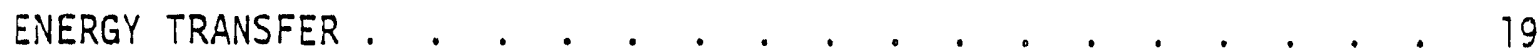

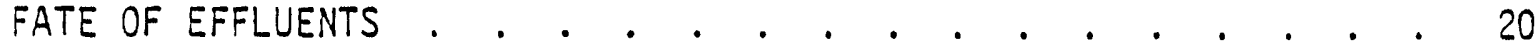

THERMAL CHANGES. . . . . . . . . . . . . . . . . . . . . 22

ECOLOGICAL EFFECTS OF THE HANFORD DISCHARGES . . . . . . . . . . . . 26

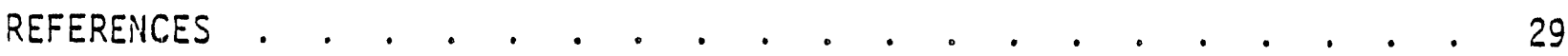




\section{TABLES}

1. Reactor Startup and Deactivation . . . . . . . . . . 1

2. Retention Basin Statistics . . . . . . . . . . . . . 9

3. Selected Dam Statistics. . . . . . . . . . . 23

\section{FIGURES}

1. Hanford Reservation. . . . . . . . . . . . . . . 2

2. Typical Limited Area for Dual Production Reactor Plants. . . . 5

3. Water Flow for a Typical Production Reactor Plant. . . . . . 6

4. Schematic of Cooling Systems for $N$ Reactor and Hanford Generating Plant. . . . . . . . . . . . . 10

5. . . . . . . . . . . . . . . . . . 14

6. . ................... . . 15

7. . . . . . . . . . . . . . . . . 16

8. . . . . . . . . . . . . . . . . 17 


\section{HANFORD PRODUCTION REACTOR HEAT RELEASES 1951-1971}

\section{INTRODUCTION}

The Hanford Reservation consists of about 570 square miles of semiarid lands in southeastern washington. The Reservation was created in the early 1940 's to permit production of weapons-grade nuclear materials. The Hanford site was ideally suited to the task for several reasons, including sparse population, ample cooling water supply, proximity to large electrical supply facilities, favorable geology and geohydrology, and low precipitation. Development of the site began with construction of B Reactor which was completed in September 1944. Eventualiy nine reactors were constructed; eight of which were employed solely for production of nuclear materials. The remaining $N$ Reactor has produced steam for Washington Public Power Supply System's Hanford Generating Plant since 1966. The initial startup and deactivation dates of the nine reactors are given in Table 1:

\section{TABLE 1. Reactor Startup and Deactivation}

\begin{tabular}{|c|c|c|}
\hline Reactor & Initial Startup & Deactivation \\
\hline$B$ & September 26,1944 & February 12,1968 \\
\hline D & December 17,1944 & June 26,1967 \\
\hline $\mathrm{F}$ & February 25, 1945 & June 25,1965 \\
\hline$H$ & October 29, 1949 & Apri1 21, 1965 \\
\hline$D R$ & October 3,1950 & December 30,1964 \\
\hline C & November 18, 1952 & Apri1 25, 1969 \\
\hline K' & January 4, 1955 & February 1, 1970 \\
\hline KE & Apri1 17, 1955 & January 28, 1971 \\
\hline $\mathrm{N}$ & December 31,1963 & Currently in Oper \\
\hline
\end{tabular}

Because all of the reactors operated with once through cooling water from the Columbia River, the plants were distributed along the river as it flowed through the Reservation. Reactor areas (100 Areas) as well as other major facility sites and roads are shown in Figure 1 as they currentiy exist. 


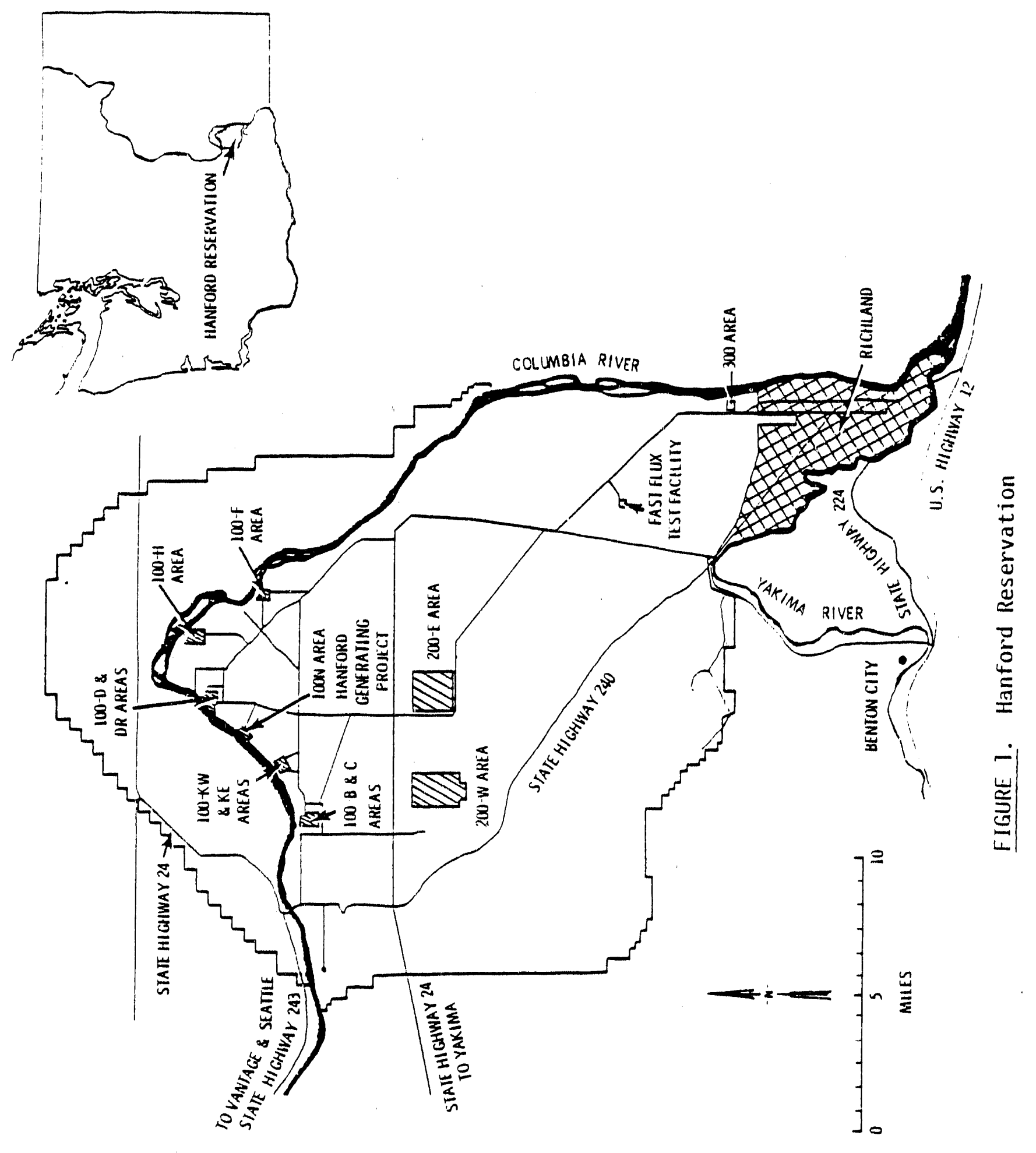


The purpose of this report is to document and detail the thermal releases from the Hanford nuclear production reactors during the period 1951 through 1971, and to put these releases in historical perspective with respect to changing Columbia River flows and temperatures. This information can also be used as a foundation for further ecological evaluations.

When examining Hanford production reactor thermal releases to the Columbia River all related factors affecting the releases and the characteristics of the river should be considered. The major considerations in the present study were the characteristics of the releases themsalves (primarily coolant flow rate, temperatures, discharge facilities, period of operation, and level of operation) and the characteristics of the river in that reach (primarily flow rate, temperature and mixing characteristics; the effects of dam construction were aiso taken into account. In addition, this study addressed ecological effects of thermal releases on aquatic species. Accordingly, this report includes discussion of the reactor cooling systems, historical heat releases, thermal mixing and transport studies, hydroelectric power development, and ecologic effects of Hanford production reactor heat releases on salmon and trout. Appendix $A$ contains reactor operating statistics, and Appendix $B$ provides computations of heat added to the Columbia River between Priest Rapids Dam and Richland, Washington. 


\section{DESCRIPTION OF THE REACTOR COOLING SYSTEMS}

The cooling system used was direct once-through cooling with river water flowing directly through the reactors. The primary circulating system is shown in Figures 2 and 3 . Figure 2 is an illustration of a typical dual production reactor area. Areas having production reactors were $100 \mathrm{~B}$ and $C, 100 \mathrm{KW}$ and $\mathrm{KE}$, and $100 \mathrm{D}$ and $\mathrm{DR}$. Areas having single reactor faciiities were $100 \mathrm{H}$ and $100 \mathrm{~F}$. The typical cooling system for the eight reactors is shown schematically in Figure 3 (the facilities at $N$ Reactor are discussed later). Figure 3 also shows the buildings (designated by numbers) that were used for different facets of cooling treatment.

Columbia River water was obtained through pump houses which enclosed 5 to 14 vertical deepwe11 pumps; the bottoms of the pump bowls were approximately $11 \mathrm{ft}$ below normal flow water elevations. (a) The intake channels from the pump houses into the river were dredged and lined with rock and concrete. River water entered the pump house deepwell through traveling screens which prevented entrance of fish and debris. Combinations of $30-i n$., 36-in., 42-in., and 48-in. lines passed circulating water from the river pump houses ( $181 \mathrm{~B} 1 \mathrm{dg}$. ) to reservoirs $(b)$ in the 182 Building and chemical treatment and filtering facilities in the 183 Building.

Although the Columbia River water is exceptionally pure it was necessary to filter and chemically treat it at the 183 Building to prevent filming in the reactor process tubes. Each reactor had a separate treatment plant consisting of a head house, raw water flume, mixing chambers, distribution

(a) Much of the information concerning details of the circulating water systems comes from References 1 and 2 which do not discuss 100-KE and $100-\mathrm{KW}$ reactor areas.

(b) Prior to plant modification in 1956-1957 under project CG-558 the reservoirs were used as the principal water supply source for the filter plants and ultimately the reactors. Under project CG-558 flow modifications were made to various plant facilities to permit significantly higher coolant flow rates and thereby increase production of nuclear materials. After CG-558 the reservoirs were used primarily for "export water" used as a source for emergency cooling. Export water was water supplied to off-plant areas such as the 200 Area and to other reactor areas as needed. 


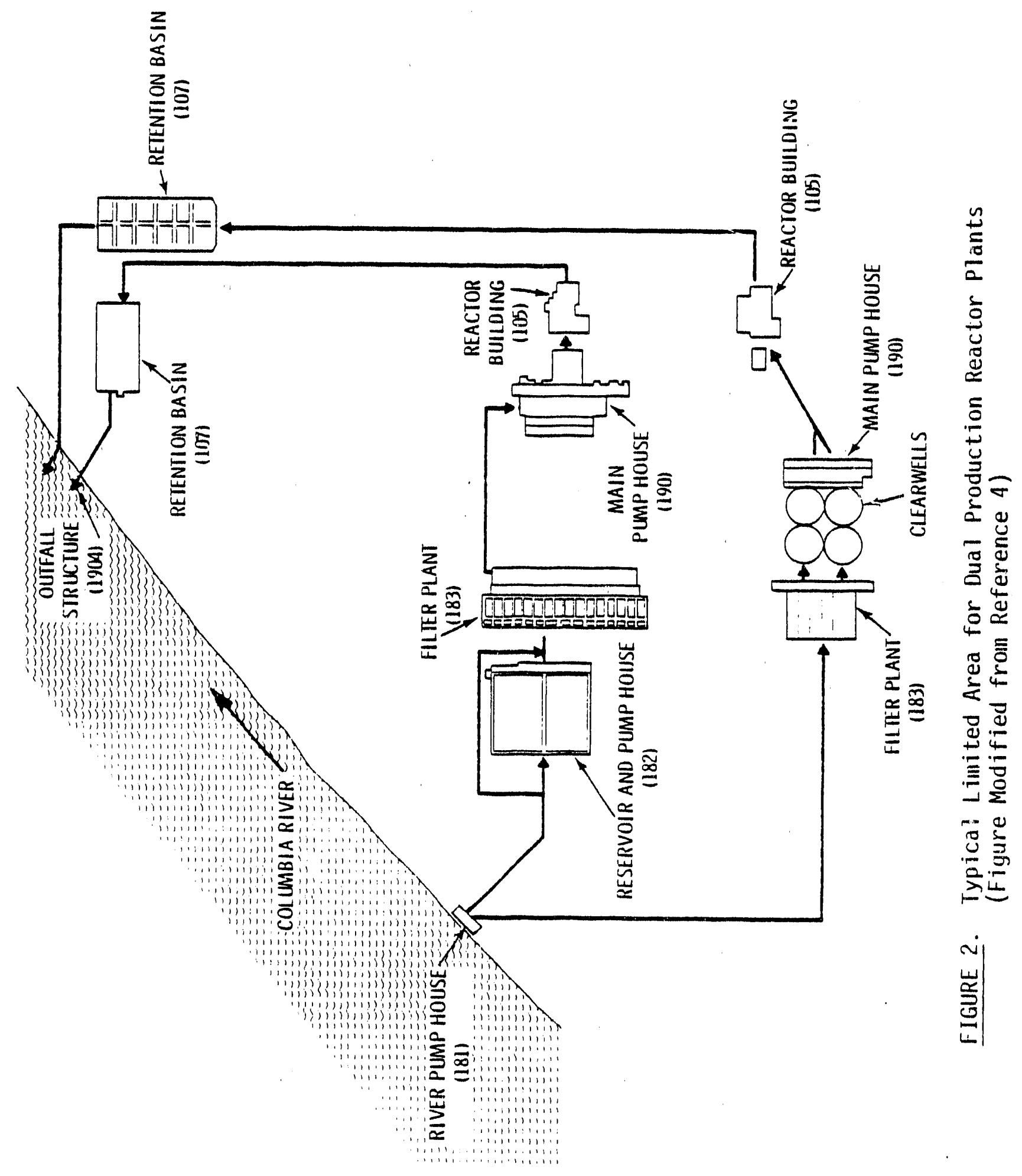




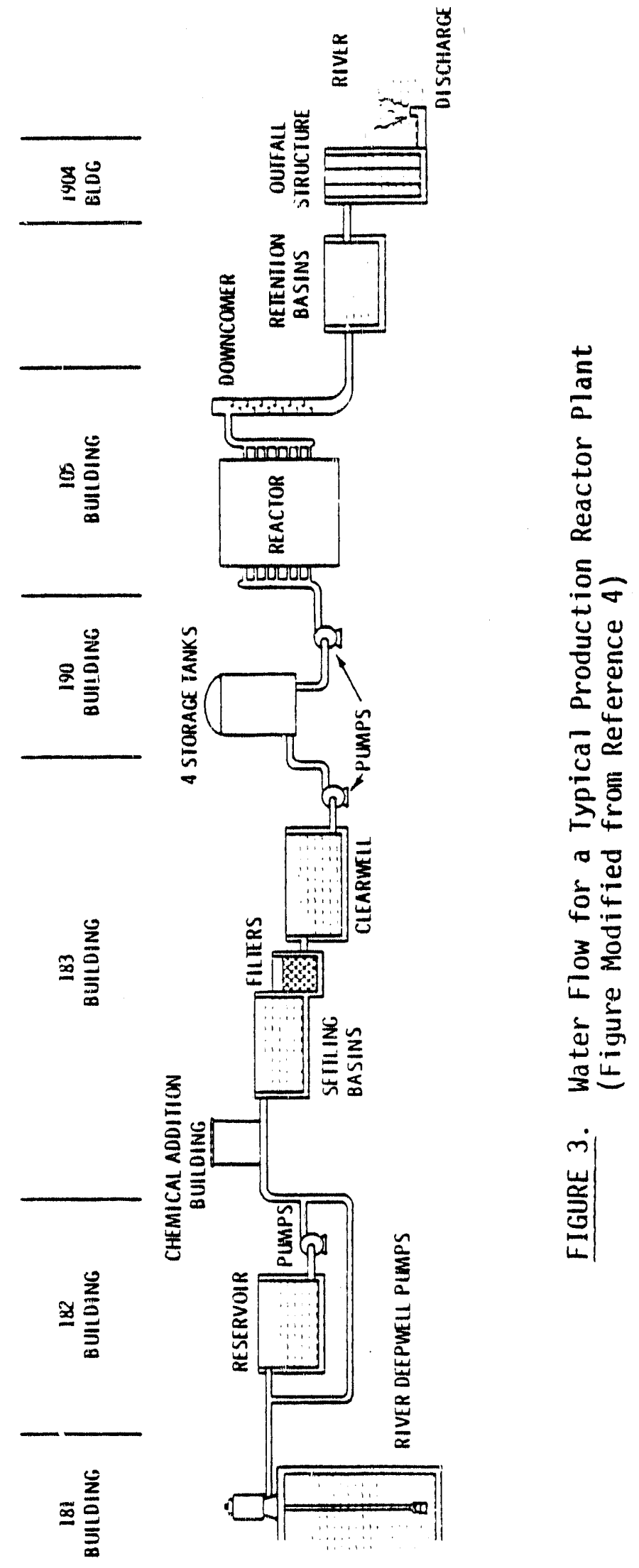


flume, flocculators, settling basins, collecting flume, influent flume, filters, effluent and backwash piping, effluent fiumes, and clearwells.

In the head house, alum (used as a flocculating agent), sulphuric acio (to control pH), and chlorine (used as an algacide for control of algae in the settling basins) were metered into the raw river water. The combination was mixed in the mixing chambers and conducted to paddle-wheel flocculators and settling basins via the distribution flume. After particulates settled out, the circulating water entered gravity flow filter beds consisting of layers of crushed gravel, sand, and crushed anthracite coal. An organic polyelectrolyte filter aid was added during filtering to increase efficiency. The filters were backwashed with water from the clearwells as necessary to maintain proper operation.

From the filters the cooling water flowed by gravity into the clearivells. The clearwells, which served to collect and store waters from the filters, had storage capacities of approximately $3 \times 10^{6}$ to $10^{7}$ gal. The filtered water was then pumped or gravity drained into four large storage tanks in the 190 Building. The storage tanks provided water to the coolant pumps that supplied cooling water to the reactor. Tank storage capacities varied frum about $7 \times 10^{6}$ to $21 \times 10^{6} \mathrm{gal}$. For normal operating flow rates there was sufficient storage capacity to operate the reactor at full flow for more than an hour without supply from the clearwells. Intake of 182 Reservoir storage between reictor areas provided additional supplies if required.

The 190 Building also housed the primary coolant pumps that supplied high pressure cooling water to the reactors, and high tanks which could supply $300,000 \mathrm{gal}$ of emergency c00ling water if pressure in the piping from the 190 Building to the reactor was lost. Gravity flow of emergency cooling water from the export water system could supply coolant if supplies in the high tanks were exhausted.

Cooling water was supplied to the reactor building (105 Building) at 600 psi. Water flowed into vertical inlet risers which paralleled each side of the front face of the reactor. The coolant flowed from these risers through as many as 464 -in. crossheaders to inlet nozzles on each process tube. 
The coolani then flowed through the process tube and around the fuel element. housed within the process tube. During irradiation the coolant was heated by the hot fuel element and adjacent graphite moderator. The coolant left the reactor in a similar manner, passing through outlet nozzles, to crossheaders, to two vertical risers which were interconnected above the reactor to a downcomer. The downcomer served to break the fall of water from the crossover piping to the effluent lines. The downcomer was vented to relieve trapped gases (air) and steam. Reactor outlet piping had a rated working pressure of $150 \mathrm{psi}$. From the downcomer the effluent moved by gravity from the reactor building through underground piping to large retention basins. The retention basins were designed to permit decay of shortlived radioisotopes. The basins served another purpose by containing high concentrations of radioactive substances released during fuel eiement failures until they could be removed to adjacent cribs for effective filtering through the ground.

The retention basins varied considerably in size al though operation was similar in all of them. Effluent entered one end of the rectangular or round retention basins, flowed through or across the basins and exited from the other side. Several of the basins had baffles to prevent the effluent from channeling in the basins. The nominal dimensions, volumes, and estimated flow-through times for the retention basins are given in Table 2. In actuality, some channeling did occur thereby reducing travel times at certain plants.

The reactor effluents left the retention basins by overflowing a weir at one end of the basin. Effluent flowed into a downpipe to underground piping leading to the outfall structure or, as necessary, to a crib for isolation. The outfall structure consisted of three compartments. The effluent flowed into one compartment, then overflowed into an adjacent chamber which led via one or two effluent pipelines (depending on the plant) center of the river for submerged vertical single port discharge. If flow through the discharge effluent lines was obstructed, or if river water elevation was extremely high, water could overflow the second chamber into a third which led via a spillway to the river shore for shoreline surface 
discharge. Submerged discharge in the center of the river was designed to provide rapid dilution with river waters, both thermally and radiologically.

TABLE 2. Retention Basin Statistics

\begin{tabular}{|c|c|c|c|c|c|c|}
\hline $\begin{array}{c}\text { Reactor } \\
\text { Basin }\end{array}$ & $\begin{array}{l}\text { Length } \\
\text { (Dia.)ft } \\
\end{array}$ & $\begin{array}{l}\frac{B a s}{\text { Width, }} \\
\text { ft }\end{array}$ & $\begin{array}{l}\text { in } \\
\text { Depth, } \\
f t\end{array}$ & $\begin{array}{l}\text { Volume } \\
103 / \mathrm{ft} \\
\end{array}$ & $\begin{array}{l}\text { Trave }(a) \\
\text { Time, hr } \\
\end{array}$ & $\begin{array}{r}\text { Flow (b) } \\
\text { Rate, gpm }\end{array}$ \\
\hline $107-B(C)$ & 450 & 230 & 16 & 1656 & 2.38 & 87,000 \\
\hline $107-\mathrm{CW}$ & $(330)$ & & 16 & 1368 & 1.96 & $87,000^{(c)}$ \\
\hline 107-CE & $(330)$ & & 16 & 1368 & 1.78 & 96,000 \\
\hline $107-0$ & 450 & 230 & 16 & 1656 & 2.33 & 89,000 \\
\hline $107-D R$ & 450 & 230 & 16 & 1656 & 2.35 & 88,000 \\
\hline $107-F$ & 450 & 230 & 16 & 1656 & 2.33 & 89,000 \\
\hline $107-H$ & 600 & 270 & 15 & 2430 & 3.26 & 93,000 \\
\hline $107-K E^{(d)}$ & $(250)$ & & 29 & $4270^{(d)}$ & 2.59 & 206,000 \\
\hline $107-K W^{(d)}$ & $(250)$ & & 29 & $4270^{(d)}$ & 2.57 & 208,000 \\
\hline
\end{tabular}

(a) Computed from assumed flow rate and calculated basin volume.

(b) Nominal values for reactor flows in 1964.

(c) Because of excessive leakage from the 107-B retention basin effiuent from $B$ reactor was routed to $107-\mathrm{CW}$.

(d) Three basins of the size given. Volume is total of all three basins.

\section{N REACTOR COOLING SYSTEM}

$N$ Reactor has a different cooling system because its main reactor oolant loop produces steam. A schematic of the cooling systems for $N$ Reactor and Hanford Generating Plant (HGP) is shown in Figure 4. There are essentially three circulating circuits. The primary system coolant picks up heat in the reactor and transfers it to the secondary system coolant in a steam generator. $N$ Reactor is a pressurized water reactor using ultrapure water as the primary coolant, operating at approximately 1200-1500 psig. (2) In the steam generator energy from the primary coolant is transferred via a heat exchanger to the secondary coolant which boils to steam. Pressure in the secondary coolant in the steam generator is about 140 psig. (3) This low pressure steam is generaliy routed to the HGP where it is used to drive 


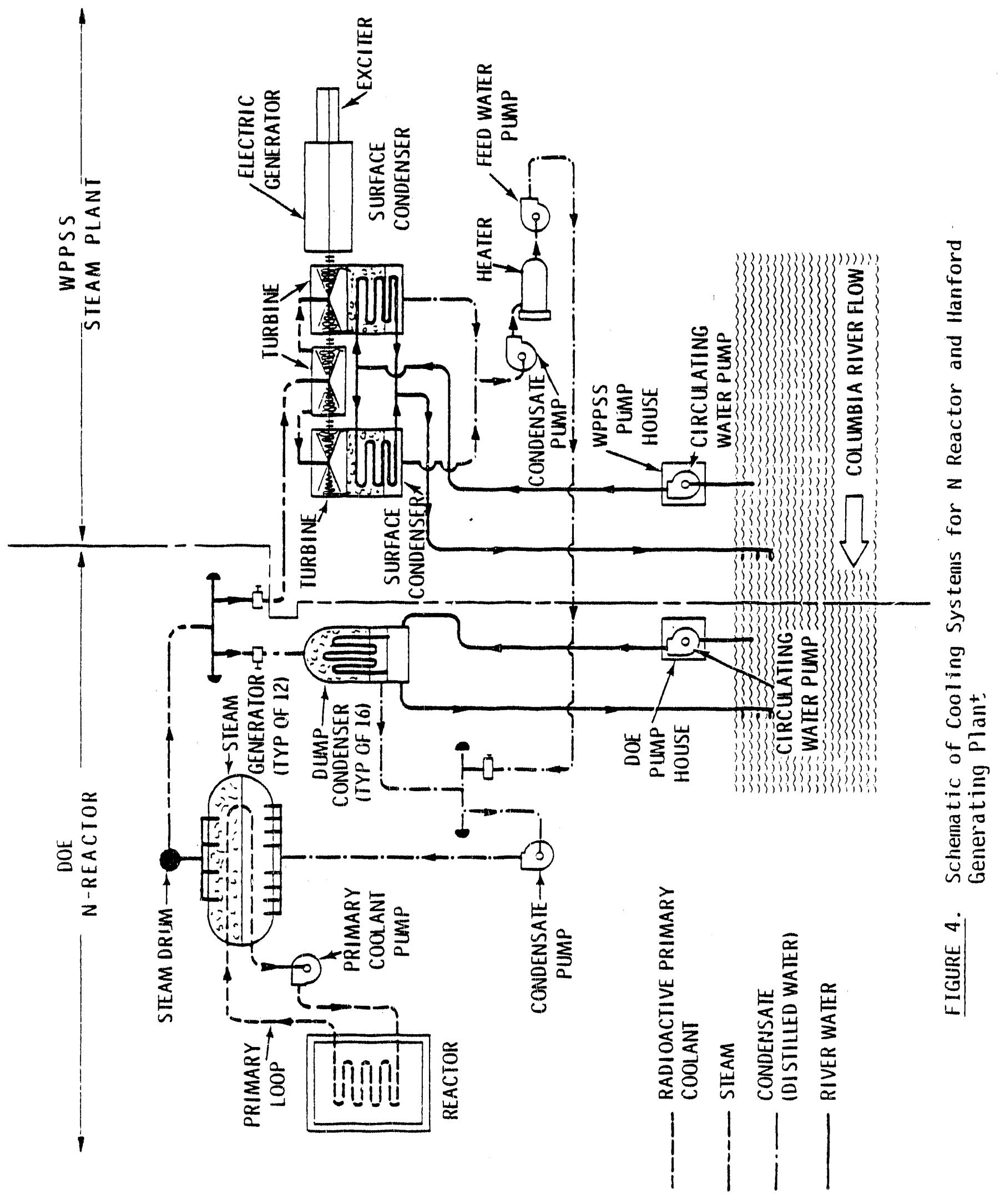


turbines, then condensed to liquid, and pumped back to the steam generator. During periods when HGP is not operating it is routed to "dump" condensers in the $100 \mathrm{~N}$ Area for condensation and return to the steam generator. In the condensers, thermal energy is transferred from the condensing steam to circulating water from the river. Water is pumped from the river through the condenser heat exchanger back to the river. This is true of both the dump condensers and the HGP condensers. The major difference is that if steam is routed to the HGP, a portion (slightly less than 25\%) of the energy in the steam can be transformed into electrical energy rather than dumped into the river.

The intakes for $N$ Reactor and HGP are very similar to the eight other production reactors; however, the discharges are somewhat different. $N$ Reactor has a single port vertical outfall as do the other reactors but with a velocity cap to provide more rapid mixing. HGP employs an outfall having four vertical ports positioned 50-ft apart on a diffuser line across the central portion of the river providing even greater mixing than the single ports. 


\section{HISTORICAL HEAT RELEASES}

The Hanford production reactors represent a unique collection of historical industrial facilities in regard to thermal energy releases to the environment. Several features of these facilities are not likely to be duplicated at any other industrially developed site. For example:

- No other facilities of any significant size discharged waste heat into the Columbia River for a considerable distance upstream and downstream of the reactor locations during the operating period of the reactors.

- The magnitude of the releases dwarf those of many comparable industrial facilities.

- Because of the nature of the plants and their discharges, excellent records exist providing reactor operating statistics.

- Reasonabiy coherent and consistent environmental analyses were performed throughout the plant operating period.

- The plant facilities were very similar and were operated in very similar manners.

- The sites are in a relatively compact arrangement.

- With the exception of the effects of dam construction and operation there was very little charige in water quality entering the Hanford Reservation during the operating period.

For these reasons the Hanford reactor heat releases are a valuable referenca point for future development in the Columbia Basin and at other sites around the nation.

\section{ENERGY OUTPUT}

When the production reactors were designed and constructed (primarily in the 1940's and early 1950's) the main concern was production of weaponsgrade nuclear materials. The early desians permitted small production rates for nuclear materials and waste heat. The reactor designs were made with little operational experience and very limited knowledge of optimal values for production parameters. Their output was intially small unit the 
design and operational characteristics were expanded to achieve greater production. The plants generaliy operated in two possible modes. Either the plant output was limited by the power level or the plant output was limited by the temperature of the effluent in the downcomer. During 1951-1955 power levels in the six older reactors rarely exceeded $6000 \mathrm{MW}$. However, in 1956 and 1957 these reactors underwent flow modifications under project CG-558. These modifications more than doubled the potential reactor sustained power levels. During the following years, as more experience was gained and minor modifications performed, the power level limits and downcomer temperatures 7 imits were successively raised; in the middle 1960's all of the reactors operated at near peak power levels. Eight of the nine production reactors were operating in 1955 ( $N$ Reactor began in 1964); however, total maximum average heat release at that time was only 6000 to 9000 MW. In March 1964 , the total maximum average heat release for these same reactors was nearly $21,000 \mathrm{MW}$.

Figures 3 through 3 illustrate the monthly energy released by the production reactors in the period 1951-1971. In these figures the total maximum average heat release is the sum of the monthly average power levels during reactor operation for a 11 of the reactors operated that month. This total represents a reasonable estimate of the peak combined heat release during the month since there would likely have been only a small portion of the time that all reactors operated during the month. Also shown in the figures is the integrated power released by the reactors in gigawatt days (GWD). This number was obtained by multiplying the average power level during reactor operation by the time during the month that the reactor operated for each reactor and summing for all the reactors. The integrated power thus represents the total energy released to the environment during the month. The third curve shown in these figures is the mean energy release to the river during the month and is computed as the integrated power divided by the number of days in the month.

The development of production capacity at Hanford can readily be seen. The maximum heat release was in December 1964 when al1 the reactors were operating and river temperatures were low. The total maximum heat discharge 
could have reached $23,501 \mathrm{MW}$ during the month. Integrated power was 604.1 GiWD and the mean monthly heat release computed to nearly $20,000 \mathrm{MT}_{t}, 19,490 \mathrm{MW}_{t}$.

Six $1250 \mathrm{MW}_{\mathrm{e}}$ nuclear generated stations today would generate $7500 \mathrm{MW}_{\mathrm{e}}$ total maximum power, and at 33\% thermodynamic efficiency, 15,000 MT total maximum heat release. Using an annual plant factor of 0.7 including a 1-month refueling outage, these six plants would yield 352.2 GWD integrated heat reluase monthly and a mean monthly (30 days) heat release rate of $11,730 \mathrm{MW}_{t}$. The Hanford production reactors exceeded 15,000 $\mathrm{MW}_{t}$ in total maximum heat release rate for 8 years between August 1959 and August 1967. Monthly integrated power exceeded 353 GWD for over 8 years during the period from December 1958 to August 1967.

Total maximum heat release rate exceeded $20,000 \mathrm{MW}_{t}$ for 13 of 15 months between December 1963 and April 1965, and 10,000 MW for more than 13 years between November 1956 and January 1970. Monthly integrated power exceeded 470 GWD in 19 months between March 1963 and April 1967; 235 GWD was exceeded for 13 years between June 1956 and June 1969. Data for the average power level during operation and the time operating efficiency (percent of month reactor operated) are given for each reactor by month in Appendix $A$ for the period 1951-1971. Also given in Appendix $A$ are the cooling water temperatures into and out of the reactor, and the nominal coolant flow rate for each reactor as recorded during the "last equilibrium operation."

The last equilibrium operation is the latest time (within the month) that the reactor operated stably at operational limits. These temperatures and flow rates should not be taken as maximum operating values, nor should they necessarily be considered as an average operating value for that parameter. Rather, they should be interpreted as typical operating values when reactor operation was stable. Computation of the power levels of the reactor using the flow rates and temperatures across the reactor will result in values not necessarily the same as those given in Appendix $A$. The average power levels during operation and the time operating efficiencies are considered accurate. 
Table A-1 shuws the total maximum average power level (or heat release) for that month (AVG. MW) and the integrated power (heat release) for the month for the combined reactors in GWD. When both $N$ reactor and HGP were operating, the difference between the energy released by $N$ reactor and the electrical production of $\mathrm{HGP}^{(a)}$ is computed as $N^{*}$ and represents the thermal energy release rate to the environment when both plants arc operating. Examination of the table shows that after $1966 \mathrm{~N}$ Reactor rarely operated when HGP could not, making $N^{*}$ a reasonable estimate of the $N$ Reactor heat release to the environment. The total maximum average heat release is the sum of the average power levels during operation for all the reactors except: when HGP was operating, for which $N^{*}$ replaced the $N$ Reactor contribution. The integrated heat release includes the $N$ Reactor thermal contribution at its related time operating efficiency as well as subtracting HGP electrica? generation at its related time operating efficiency. The integrated heat release represents the total energy released to the environment for the month. The mean monthly heat release rate to the environment may easily be computed as the integrated power, GWD, divided by the number of days in the month.

\section{ENERGY TRANSFER}

The energy produced by the reactors did not all reach the Columbia River There were several mechanisms for energy transfer to the atmosphere and the ground before entering the river. For example, a certain amount of heat transfer occurred between the piping and the soil. No data exist to determine the magnitude of that heat transfer; however, it is expected to be relatively small due to the relative insulating value of soil. A far more signficant heat transfer mechanism for the eight reactors was the heat transfer to the atmosphere and ground from the retention basins. (b) During operation the hot effluent (occasionally greater than $90^{\circ} \mathrm{C}$ ) passing through the retention basins transferied great quantities of heat and mass to the atmosphere in the form of vapor plumes. These plumes rose 1000 or $2000 \mathrm{ft}$

(a) All energy rates in the Appendices are given as thermal except for HGP energy rates which are electrical.

(b) $N$ Reactor did not empty retention basins and experienced no known leakage between the dump condensers and the river shoreline. 
in the air under certain conditions. When evaporative heat loss dominated heat transfer to the atmosphere. Many of the retention basins leaked large quantities of effiluent to the ground waters which eventually flowed to the Columbia River near the plant sites.

While ground-water flow speeds into the Columbia River from the retention basins in the zones bordering the river were between 10 and $30 \mathrm{ft} / \mathrm{day}$, normal ground-water influxes to the columbia are astimated to cuntribute over four times the thermal energy leaked from reactor retention basins. (4) The piping between the 105 Reactor Buildings and the retention basins was also observed to leak. The water table was observed to rise in the rogions of the retention basins and effluent lines. Large portions of these locally raised water tables were at elevated temperatures. The six older reactor areas had ground-water temperatures in excess of $70^{\circ} \mathrm{C}$ in extensive zones underneath the retention basins. Leakage from the retention basins is estimated to have been from 1 to $5 \%$ of the effluent flow from the reactor based on available information. (4)

Based on temperature measurements of effluents in the downcomer and leaving the retention basins, an estimated 3 to $8 \%$ heat loss occurred as a result of heat transfer to the atmosphere. There was also considerable leakage from piping leading from the retention basins to the discharge in the center of the river, as evidenced by thermal plume surveys with infrared imagery. (5) It is therefore very difficult to estimate the true heat releases from the Hanford production reactors to the Columbia River. A reasonable estimate is that probably 3 to $10 \%$ of the reactor thermal energy generated was dissipated to the atmosphere before effluents entered the river, leaving 90 to $97 \%$ to enter the river.

\section{FATE OF EFFLUENTS}

Numerous studies have been performed to determine the fate of effluents that entered the river from the production reactors. Mixing near the discharges was observed to be rapid vertically so that even the highly buoyant discharges from the production reactors were completely mixed vertically within a few hundred yards of the outfall. Mixing laterally was observed to proceed much slower than vertically. Narrow ribbons of effluent plume were 
often observed downstream until major river features (such as islands and bends in the river) enhanced lateral mixing. Lateral temperature profiles at Richland, Washington, demonstrated that complete lateral mixing was not obtained even to that point. Lateral mixing coefficients were observed to vary from about $0.5 \mathrm{ft}^{2} / \mathrm{sec}$ to $12.6 \mathrm{ft}^{2} / \mathrm{sec}$ depending on the river location and the buoyancy (1ateral mixing increased for buoyant cases). (6) Generally acceptable values for lateral eddy diffusivities upstream of Locke Is land are near $2 \mathrm{ft}^{2} / \mathrm{sec}$. (6) Dilution of effluents near the discharge have been measured. (7) Dilution factors varied significantly for varying flow conditions and reactor discharges. The dilutions to the points where the plumes were first observed to strike the surface (about $50 \mathrm{ft}$ downstream) were estimated to be from 2 to 7 for 3 river flow of 36,000 cfs. (a) For the same river flow dilution factors were estimated to be from 7 to 17 at 100 yd downstream from where the plume surfaced, and from 17 to 37 at 400 yd downstream. (a) As a general rule the dilution incroased directly with river flow rate such that at a river flow of 360,000 cfs dilutions would be an order of magnitude larger than those estimated at 36,000 cfs. As would be expected, the data supporting those analyses display considerable scatter evidencing highly varying turbulent characteristics.

(a) Dilutions were computed based on maximum plume measured temperatures and efficiency and effluent temperatures recorded at the reactor downcomer. 


\section{THERMAL CHANGES}

Because of the magnitude of energy released to the Columbia River by the production reactors, the importance of the river for commercial fishery on the Pacific Coast, and the emerging concern with thermal discharges as "pollution," numerous studies have been performed relating Hanford heat releases to i) power development on the columbia and 2) environmental effects of large heat releases. The emerging interest in the environment and resulting environmental regulation brought about an extensive effort by Hanford researchers to characterize and model the extent and persistence of the Hanford thermal discharges. Additional monitoring'was performed on special studies and analyzed. (8-11) A temperature monitoring system already in existence on the Columbia was refined in 1964 to provided added data and remove biases that may have existed in firior monitoring programs. Analysis of data from this network and other studies with special computer routines and the development of various river reservoirs computer models for heat transfer and heat budget simulation led to several interesting observations. ranging from the effects of the dams on the hydrothermal character of the Columbia River to the persistence of Haiford heat additions downstream of the Hanford Reservation.

The Columbia River flows generally east across the northern portion of the Hanford Reservation, then turns south forming the eastern boundary. The Columbia is the second largest river in the United States with a discharge at its mouth slightly larger than the Ohio River. (12) Because of the large discharge, low suspended sediment load, and steep side slopes characterizing the river, significant hydroelectric power development has occurred. At present the only nontidal free flowing reach of the river is the 49-mile length from the head of McNary Reservoir (behind McNary Dam) to Priest Rapids Dam [river mile (RM) 397]. Except for about 9.5 miles immediately below Priest Rapids Dam, this reach lies completely within or is bounded by the Hanford Reservation.

The period of major construction and operation of the Hanford production reactors (1951-1971) was also the period of major dam construction on the 
Columbia. Table 3 shows the river mile, the total storage, and the completion date for all U.S. dams on the mainstem of the Columbia River. In addition to these dams other major dams on the Snake River (Ice Harbor, Lower Monumenta 1, Little Goose, Lower Granite, and others) contribute to power development, navigation and flood control. However, since the Snake River enters the Columbia below the Reservation (about RM 325) flow control on the Snake has no effect on the Columbia River flow past the Hanford Reservation. Additionai dam construction on the upper Columbia or its tributaries in Canada and the U.S. (Mica, Duncan, Hungry Horse, Libby, and Arrow) will increase storage volumes fivefold over that of U.S. dams on the mainstem of the columbia and aid significantly in flow control.

IABLE 3. Selected Dam Statistics

\begin{tabular}{|c|c|c|c|c|}
\hline Dam & River Mile & $\begin{array}{c}\text { Reservoir Length } \\
\mathrm{mi}\end{array}$ & $\begin{array}{c}\text { Storage Capacity } \\
1000 \text { acre-ft } \\
\end{array}$ & Completion Year \\
\hline Bonneville & 146 & 48 & 87 & 1938 \\
\hline The Dalles & 192 & 24 & 53 & 1957 \\
\hline John Day & 216 & 75 & 535 & 1968 \\
\hline MeNary & 292 & 59 & 185 & 1953 \\
\hline Priest Rapids & 397 & 56 & 44.8 & 1959 \\
\hline Wanapum & 415 & 18 & 160.8 & 1965 \\
\hline Rock Is land & 453 & 20 & 8.6 & 1933 \\
\hline Rocky Reach & 474 & 42 & 36 & 1961 \\
\hline Wells & 516 & 28 & 125 & 1970 \\
\hline Chief Joseph & 545 & 51 & 175 & 1955 \\
\hline Grand Coulee & 597 & 157 & 5232 & 1941 \\
\hline
\end{tabular}

Dam construction has had a major influence on Columbia River flows and temperature, thereby affecting both Hanford reactor operations and analyses of environmental effects of those operations. The impoundment of waters in the Snake and Upper Columbia Rivers has substantially reduced high water discharge. This is the intended effect of the 1971 Columbia Treaty between the United States and Canada, which provided for flood control on the Columbia 
and tts tributaries. The effective storage of spring and summer runoff waters has signficantly aided in meeting large power demands during the winter through hydroelectric generation. At the same time, storage has created a temporal shift in the river temperature cycle. For example, the construction of Grand Coulee Dam produced a permanent delay of about 30 days in arrival of peak temperatures at locations downstream. Similarly, waters with peak temperatures arrive at Priest Rapids about 7 to 10 days later than they reach Rock Island. (13) Previously, peak temperatures were simultaneous at these locations. The shifts are generally attributed to increased flow times through reservoirs behind the dams.

Another temperature effect observed as a result of dam construction or the Upper Columbia is the lowering of peak and average temperatures. It has been predicted that the average August-September temperatures at Priest. Rapids Dam after completion of the Canadian Dams will be nearly $2^{\circ} \mathrm{C} 1$ ower than the average 1961-1967 temperatures. (13) Construction of the Calladian Dams is predicted to lower temperatures of water emerging from Grand coulee Dam by as much as as $4^{\circ} \mathrm{C}$ as compared to average peak temperatures for the period 1929 through i957. (13) Lower Columbia River temperatures and cycle shifting are most pronounced upstream from the mouth of the Snake River. The Columbia seems to equilibrate considerably between McNary Dam and Bonneville Dam. The bulk of this is due to climatological and hydrodynamic conditions characteristic of that reach. The Snake River raises temperatures in the Columbia particularly in late summer.

Additional findings concerning thermal characteristics of the columbia River are as follows: (15)

- Dam impoundments respond much more slowly to thermal additions than free flowing river reaches evidencing larger heat transfer coefficients for free flowing rivers.

- Columbia River temperatures appear to be closely related to river management practices (hydroelectric and storage operations).

- Temperatures in the fres flowing reach between Priest Rapids and Richland gain from 0.5 to $0.90^{\circ} \mathrm{C}$ in August and September due to natural heating in the absence of thermal discharges. 
- The majority of thermal energy released by the production reactors in 1969 was dissipated to the atmosphere before effluents reached the confluence with the Snake. At whe Oregon-Washington border between 60 and $95 \%$ of the thermal additions of the production reactors had been dissipated, with the average dissipation being $65 \%$. At Bonneville only about $20 \%$ of the production reactor heat release (1969) remained in the river.

- An annual thermal addition of $4000 \mathrm{MW}_{\mathrm{t}}$ is attributable to the Snake River. Ouring August and early September the addition is nearly twice the annual average. With the completion of the Canadian Treaty Dams this summer addition may rise to over 15,000 $\mathrm{MW}_{t}$.

- Thermal additions in winter persist further downstream than those same discharges in summer.

- Studies concerning the thermal capacity of the columbia indicate that there is a potential for addition of from 20 to $25 \mathrm{GW}_{t}$ in the zone between Grand Coulee and Pasco, Washington, within state water quality criteria. (16)

The data in Appendix $B$ illustrate the magnitude of thermal changes in the Hanford reach of the Columbia. Specifically, these data include the monthly average Priest Rapids temperature, Richland temperature, Columbia River discharge; the computed heat additions between Priest Rapids and Richland (based on their temperatures and the flow of the Columbia); the monthly mean heat additions by the Hanford production reactors (which lie between these sampling points); and the difference between the computed means and the reactor heat additions for the period of June 1964 through December 1971. The values given in Appendix $B$ demonstrate that flow management tends to have a large influence on the natural heat gain. During high flow periods computed naturai monthly mean heat gains often exceeding 20,000 $\mathrm{MW}_{t}$ were observed. During low flow periods the hanford production reactor contributions formed a large part of the gross thermal gain of the river. 


\section{ECOLOGICAL EFFECTS OF THE HANFORD DISCHARGES}

As early as 1945 ecologists were studying the effects of the Hanford production reactor discharges on the flora and fauna of the Columbia River in the Hanford reach. Generally, these studies have endeavored to determine the effect of Hanford production reactor operations on economically important species, primarily salmon and trout.

Effects considered include thermal shock, thermal tolerance, upper thermal lethal limits, and, to a limited extent, temperature in regard to infec-

tious diseases and gas bubble disease. Additional studies have been performed on migrating fish past the discharges, on the number of fish spawning in the Hanford reach, and on the effects of temperature on annual fish and insect cycles. These studies have demonstrated the following results: $(17)$

- "Cold water" fish such as salmon have a much narrower tolerant temperature band than other fish; duration of exposure plays a critical part in loss of equilibria and mortality.

- Field studies from March through September 1968 and 1969 were conducted to determine mortality of juvenile salmonids drifted through effiuent plumes in liveboxes. Drifts through shoreline areas near seepage from retention basins resulted in significant mortalities among only a few test groups. Drifts through midriver effluent plumes resulted in losses only during unfavorable late summer conditions.

- "Columnaris" disease (a myxo-bacterial infection) associated with the Columbia River in warmer months has not been linked to the Hanford discharges. Mortality of fish subjected to large doses of Columnaris organisms was higher in warmer waters than cooler. Fish ladders appear to have much higher concentrations of the organism than other river locations.

- The problem of nitrogen supersaturation, which causes gas-bubble disease, may be enhanced in warmer water temperatures. Nitrogen supersaturation is linked primarily to entrainment and compression of air in dam spillways. Gas-bubble disease was not an obvious problem in the Hanford 
reach; however, heat releases at Hanford may have contributed in a very minor way to occurnence at downstream dams.

- Rainbow trout and chinook salmon were selectively preyed upon by larger fish after being subjected at sub-lethal exposures to water at lethal temperatures (i.e., thermally shocked) in the laboratory. Significani increases in predation rates were found when chinook salmon and rainbow trout received thermal doses that were 10 and $20 \%$ of doses causing equilibrium loss.

- Juvenile fish appeared to be more resistant to warm temperature effects than adults.

- Migrating fish appear to prefer shoreline areas particularly the area across from shoreline seepages of reactor effluents. Definite rheotaxis (thermal avoidance) was exhibited by migrating fish in the region of the shoreline effluent seepages near the reactor retention basins.

- Changes in the timing of emergence of caddisflies (Trichoptera) have been related to river temperatures. Caddisfly emergence occurred a few weeks earlier in waters immediately downstream of the effluent discharges, slightly later in well mixed waters further downstream, and latest upstream of the reactors. It is felt this would have little effect on annual biologic cycles of juvenile fish of which $96 \%$ of their diet is adult and larval insects (the bulk of which are midges).

- The annual census of spawning fall chinook salmon in the Hanford reach, begun in 1947, has failed to illustrate any deleterious effects of the Hanford discharges. Dam construction has displaced many spawning fish such that rearing nests in the Hanford reach have generally increased. This indicates that spawning in the Hanford reach has not been despoiled, and that Hanford heat releases have not resulted in a catastrophic fisheries disaster.

- Tests on manually spawned fertilized salmon eggs taken from fish captured below Priest Rapids and reared at temperatures elevated above those in the river showed normal mortality (for hatchery operations) and increased body weight (factor of 1.4 for each $2^{\circ} \mathrm{F}$ rise above 
ambient to $12^{\circ} \mathrm{F}$ ) for the eggs and young. The question exists whether or not warmer winter and spring waters might not increase body weight of migrants thereby improving survivorship until seaward migration. (Size of young at release from hatcheries is known to influence the number of adults returning.)

A general conclusion is that the Hanford production reactor thermal discharges have had no detectable harmful influence on the Hanford reach aquatic environment including salmon and trout.

Dam development on the Columbia and its tributaries has had a major effect on migrating salmon and trout. Although steps have been taken to mitigate the influence of dam construction on these anadromous fish (fish ladders, restocking, etc.), there is little doubt that dams have contributed to reducing or eliminating return of spawning fish to certain portions of the Columbia and its tributaries, increased mortality of spawning fish through mechanical stresses, increased incidence of infectious disease and gas bubble disease, and caused relocation of major spawning grounds.

The influences of dam construction and operation and other factors (e.g., irrigation return) on the Columbia River fisheries and the Hanford aquatic ecology tend to mask the effects of the Hanford production reactors, and consequently, a definitive link between changes in the aquatic ecology and fisheries and the operations at Hanford is difficult to establish. Without segregating the effects of dams, irrigation and Hanford operations, it is unlikely that any discernible deleterious environmental effect can be attributable to Hanford production reactor operations. 


\section{REFERENCES}

1. Hazards Summary Report: Volume 3 - Description of the 100-B, 100-C, $100-0,100-0 R, 100-F$ and $100-H$ Production Reactor Plants. HW-74094, prepared by the Staff of the Irradiation Processing Dept. , Hanford Atomic Products Uperation, General Electric Co., Richland, WA 99352, Apri1 1, 1963.

2. N. R. Miller and R. E. Trumble, N-Reactor Hazards Summary Review (Phase I, Plutonium Production Oniy), Volume 3, Heat Dissipation Plant and Auxilliary Systems. HW-76930, N-Reactor Dept., Hanford Atomic Products Operation, GeneraT Electric Company, Richland, WA 99352, Apri1 15, 1963.

3. Selected "Summaries of WPPSS Hanford Generating Plant Monthly and Annual Operation Statistics," 1966 through 1971.

4. D. J. Brown, Status of the Ground Water Beneath Hanford Reactor Areas January, 1962 to January, 1963. HW-77170, Hanford Atomic Products Operation, General Electric Company, Richiand, WA 99352, April 1963.

5. J. R. Eliason, Thermal Mapping of the Columbia River at Hanford Using an Infrared Imaging System. BNWL-CC-1074, Battelle, Pacific Northwest Laboratories, Richland, WA 99352, February 1967.

6. J. C. Sonnichsen, Jr., D. A. Kottwitz, and R. T. Jaske, Dispersion Characteristics of the Columbia River Between River Miles 385 and 355. BNWL-1477, Battelle, Pacific Northwest Laboratories, Richland, WA 99352, October 1970.

7. 3. P. Corley, Effluent Plume Temperature Data. BNWL-CC-1628, Battelle, Pacific Northwest Laboratories, Richland, WA 99352, June 1968.

8. 3. K. Soldat, A Compilation of Basic Data Reiating to the Columbia River, Section 8 - Dispersion of Reactor Effluent in the Columbia River. HW-69369, General Electric Hanford Atomic Products Operation, Richland, WA 99352, November 16, 1962. (Also see Section 3 - Temperature, Section 4 - Chemical Characteristics, and Section 5 - Hydrography).

9. J. P. Corley, Effects of Hanford Operations on Columbia River Temperatures - Interim Report. HW-76210, General Electric Hanford Atomic Products Operation, Richland, WA 99352, February 13, 1963.

10. J. P. Coriey, Effects of Hanford Operations on Columbia River Temperatures - Interim Report No. 2. HW-80888, General Electric Hanford Atomic Products Operations, Richland, WA 99352, December 3,1964.

11. J. P. Corley, Inter-Reactor River Temperature Data. BNWL-CC-807, Battelle, Pacific Northwest Laboratories, Richland, WA 99352 , September 9, 1966. 
12. F. van der Leeden, Water Resources of the World: Selected Statistics. Water Information Center Inc., Port Washington, NY, 1975.

13. R. T. Jaske, Potential Thermal Effects of an Expanding Power Industry: Columbia River Basin. BNWL-1646, Battelle, Pacific Northwest Laboratories, Richland, WA 99352, April 1972.

14. R. T. Jaske and D. G. Daniels, Simulation of the Effects of Hanford at the Washington-Oregon Border. BNWL-1344, Battelle, Pacific Northwest Laboratories, Richland, WA 99352 , July 1970.

15. R. T. Jaske, and M. D. Synoground, Effect of Hanford Plant Operations on the Temperature of the Columbia River 1964 to Present. BNWL-1345, Battelle, Pacific Northwest Laboratories, Richland, WA 99352, November 1970.

16. R. T. Jaske, Potential Thermal Effects of an Expanding Power Industry: Columbia River Basin. BNWL-1646, Battelle, Pacific Northwest Laboratories, Richland, WA 99352, Apri1 1972. 
APPENDIX A

HISTORICAL HANFORD PRODUCTION REACTOR OPERATING STATISTICS 


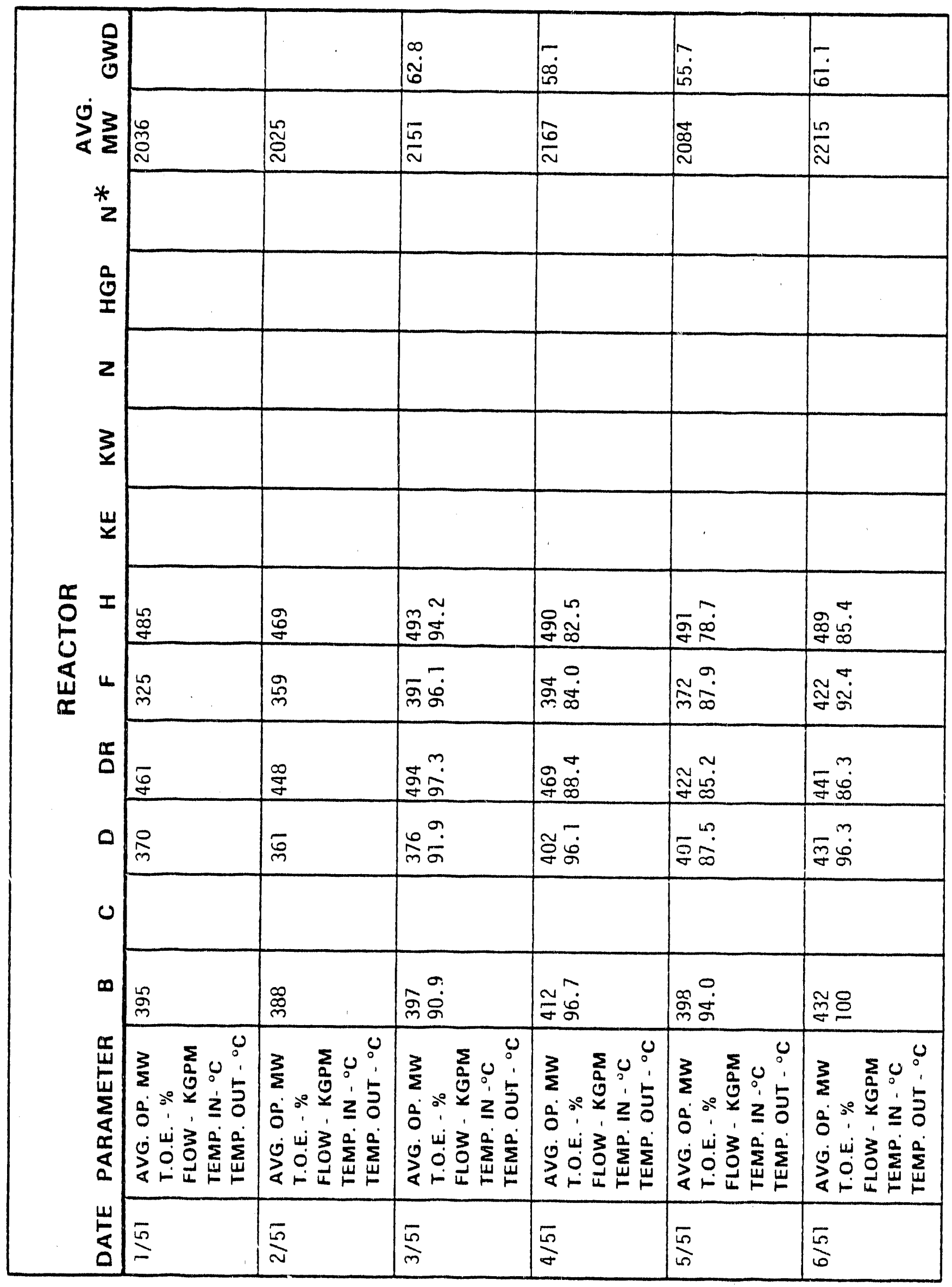




\begin{tabular}{|c|c|c|c|c|c|c|}
\hline$\sum_{0}^{0}$ & $\begin{array}{l}\infty \\
\infty \\
0 \\
0 \\
\end{array}$ & జֶ. & $\frac{1}{6}$ & نِ & ن. & : \\
\hline$\stackrel{丶}{<}_{<}^{0} 3$ & $\frac{9}{2}$ & 芯 & $\underset{\infty}{\infty}$ & 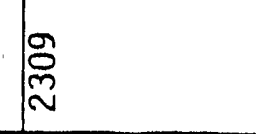 & $\frac{E}{N}$ & $\stackrel{\infty}{\infty}$ \\
\hline$\stackrel{*}{z}$ & & & & & & \\
\hline 仓़ & & & & & & \\
\hline$z$ & & & & & & \\
\hline$z_{y}$ & & & & & & \\
\hline$\underset{\mathbf{y}}{\breve{u}}$ & & & & & & \\
\hline & 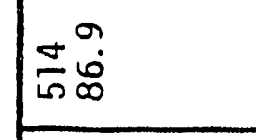 & 웅 & 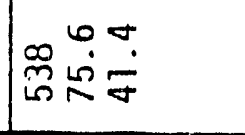 & 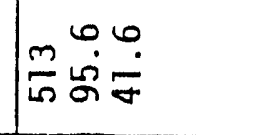 & مَّ & 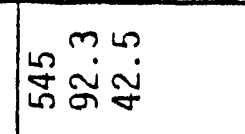 \\
\hline 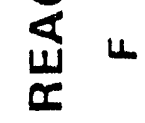 & 象官 & $\bar{\alpha}$ & 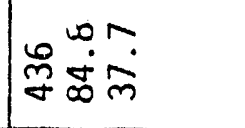 & 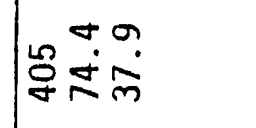 & $\begin{array}{l}\infty \\
\frac{\infty}{\sigma} \text { gin. } \\
\sigma\end{array}$ & 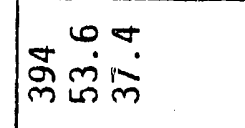 \\
\hline$\stackrel{\pi}{\Delta}$ & 妾 & 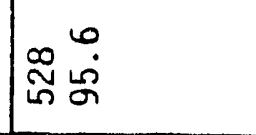 & 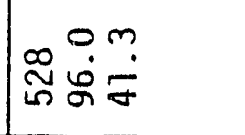 & 芯家京 & 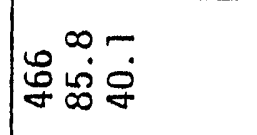 & 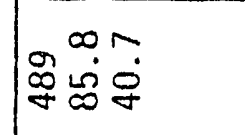 \\
\hline 0 & 繁安 & $\stackrel{\sim}{\tilde{\sigma}} \stackrel{\infty}{\infty}$ & 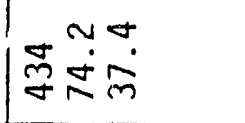 & 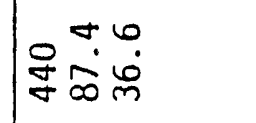 & 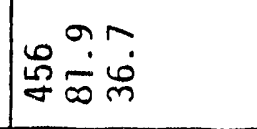 & 我- \\
\hline$\infty$ & 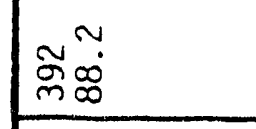 & 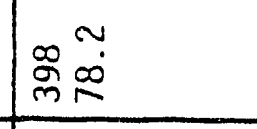 & 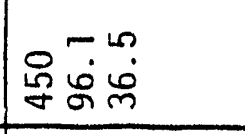 & 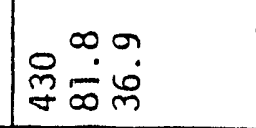 & 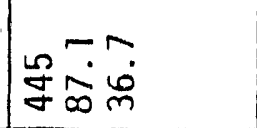 & $\bar{\gamma} \hat{\phi} \dot{\Phi}$ \\
\hline 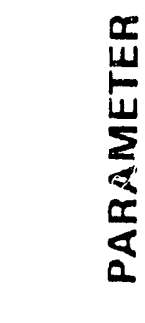 & 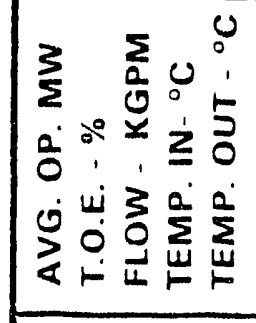 & 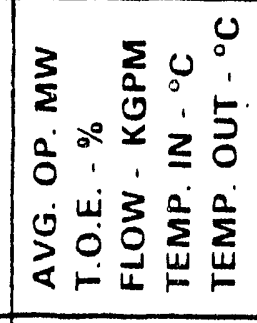 & 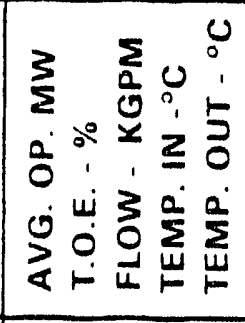 & 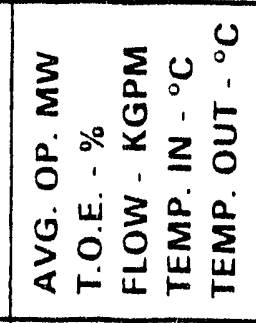 & 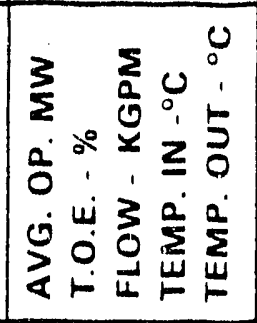 & 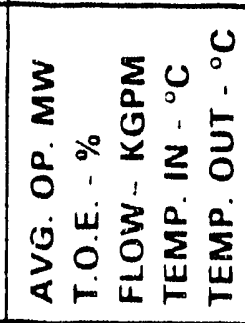 \\
\hline$\stackrel{\breve{g}}{\underline{G}}$ & $\frac{5}{2}$ & $\frac{\sqrt{5}}{\infty}$ & $\frac{5}{2}$ & $\overline{1}$ & $\stackrel{\Sigma}{\Xi}$ & $\stackrel{5}{\stackrel{5}{\underline{N}}}$ \\
\hline
\end{tabular}




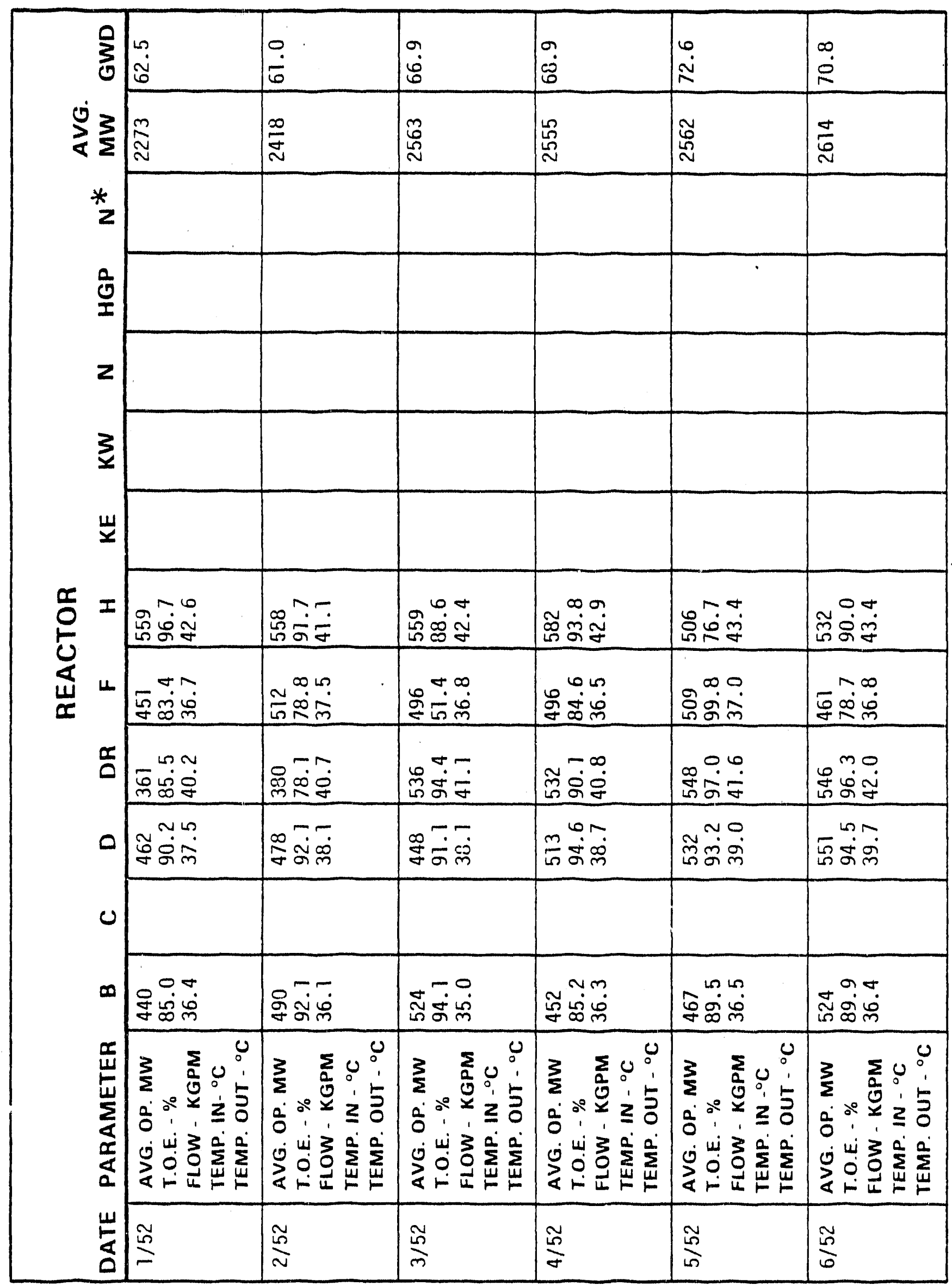




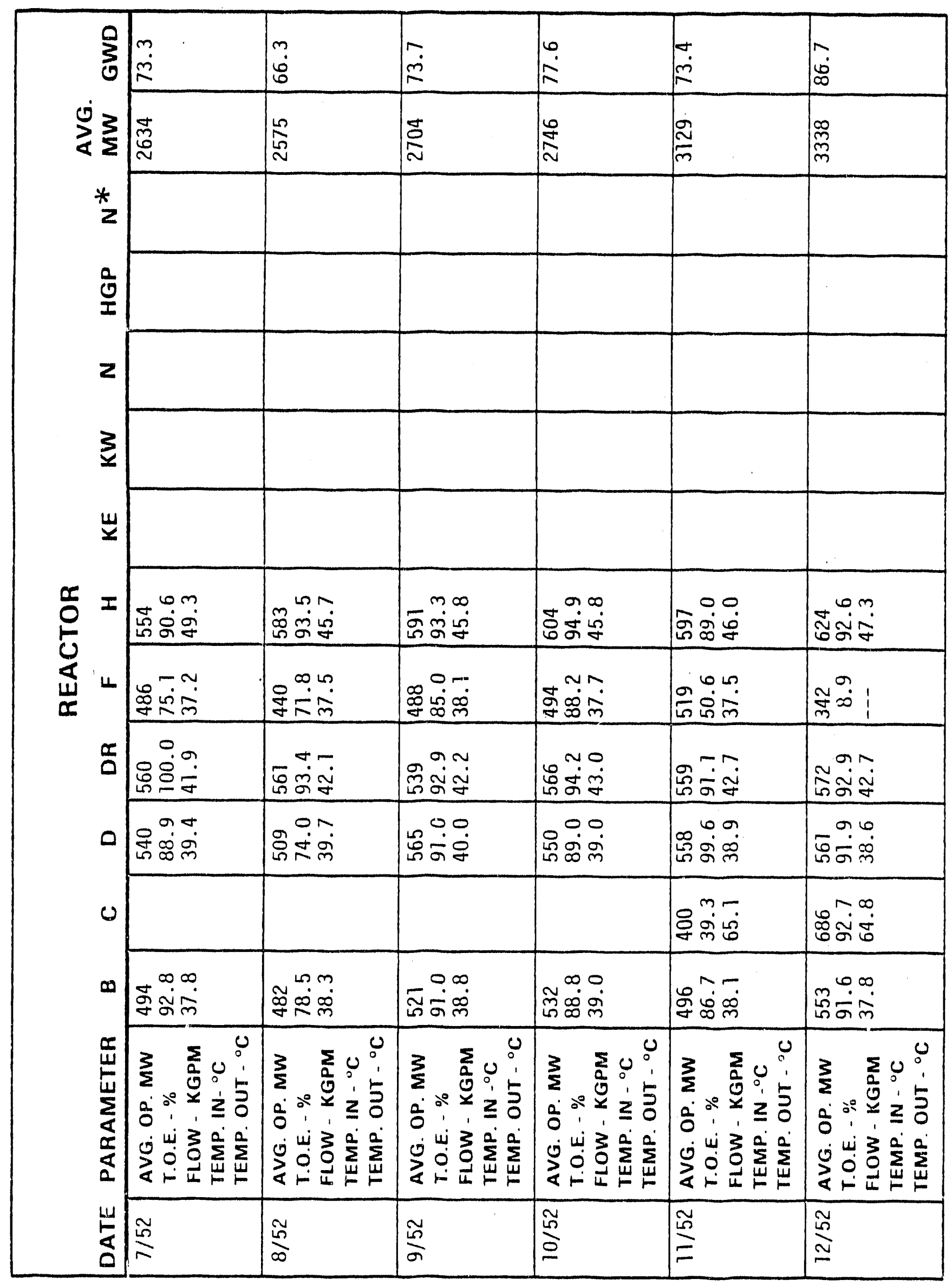




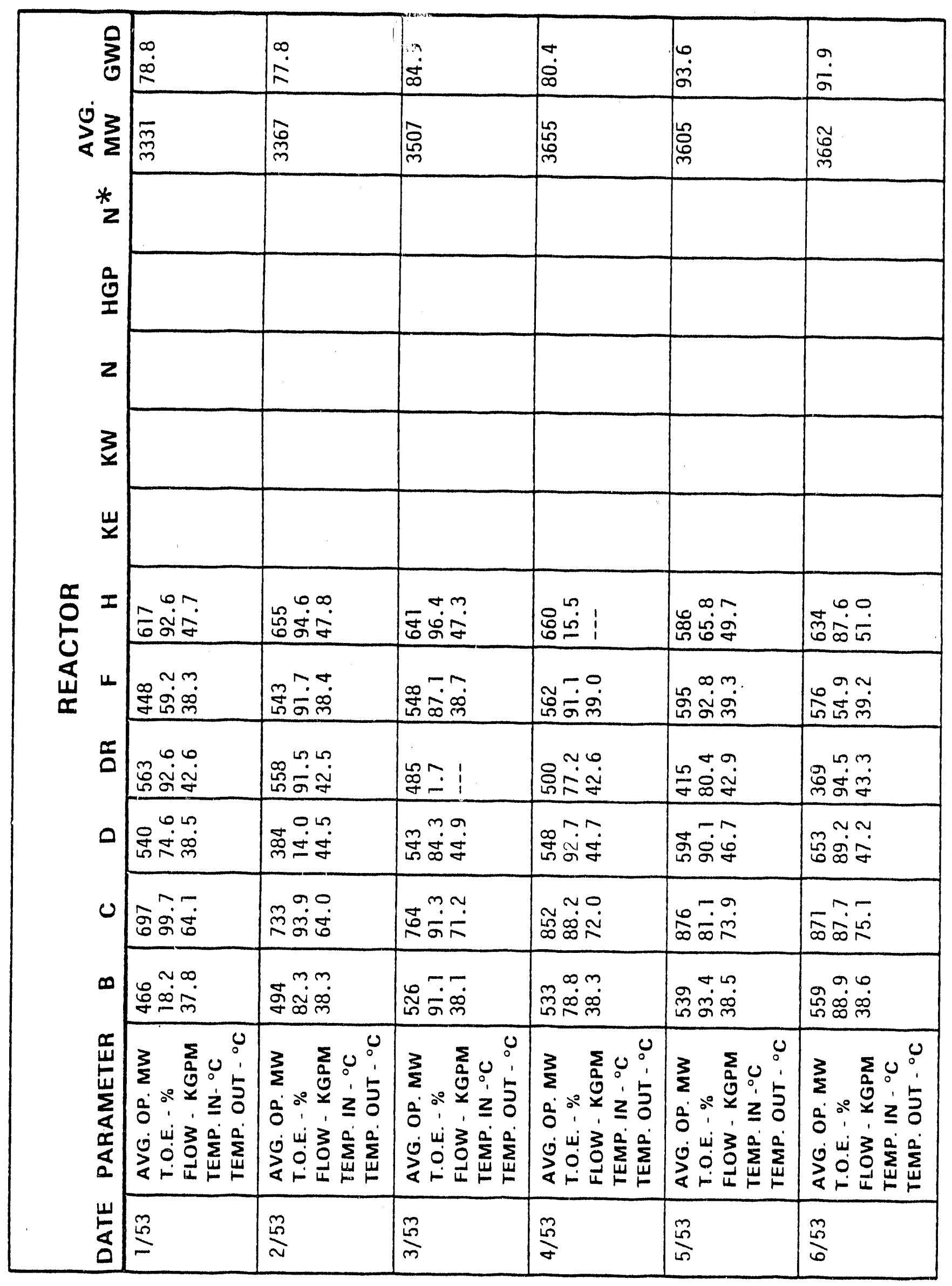




\begin{tabular}{|c|c|c|c|c|c|c|}
\hline 令 & $\hat{\dot{\rho}}$ & $\begin{array}{l}m \\
\dot{\rho} \\
\dot{\rho} \\
\dot{\rho}\end{array}$ & $\frac{a}{a}$ & $\begin{array}{l}\infty \\
\dot{g} \\
\dot{g}\end{array}$ & 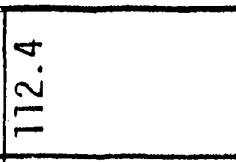 & $\hat{\Xi}$ \\
\hline$\sum_{<}^{0} \sum_{\Sigma}^{3}$ & | & స్ల్ & 总 & $\stackrel{\infty}{\sigma}$ & $\frac{\tilde{\alpha}}{a}$ & 多 \\
\hline * & & & & & & \\
\hline$\frac{0}{1}$ & & & & & & \\
\hline$z$ & & & & & & \\
\hline$z_{x}^{3}$ & & & & & & \\
\hline$\underline{\Sigma}$ & & & & & & \\
\hline & 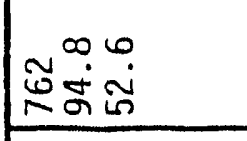 & 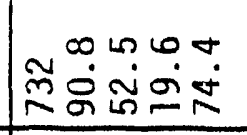 & 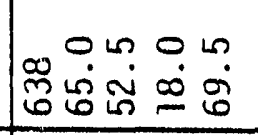 & 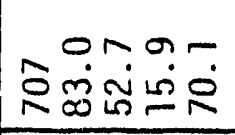 & 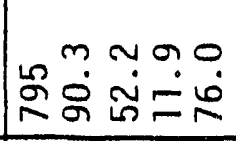 & 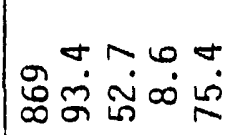 \\
\hline & 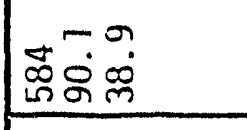 & 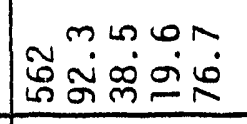 & 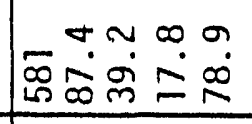 & 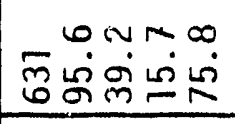 & ⿸尸匕 & 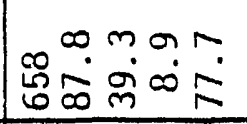 \\
\hline 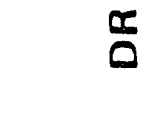 & 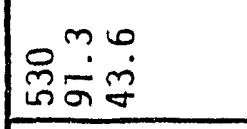 & ஜு & 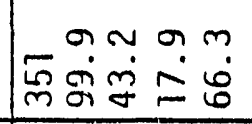 & 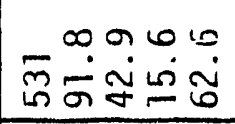 & 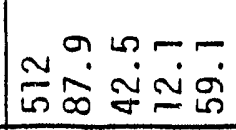 & 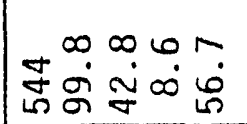 \\
\hline 0 & | & 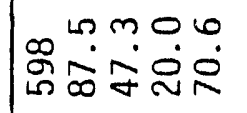 & 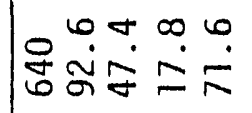 & ஜூன்ச் & 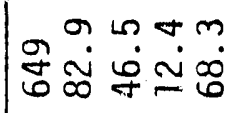 & किष्ठ \\
\hline u & 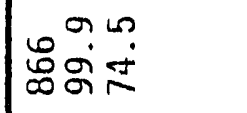 & 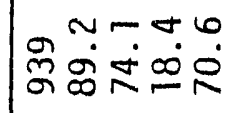 & 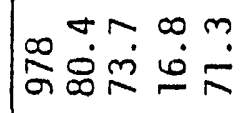 & 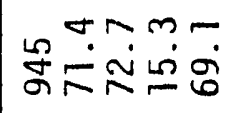 & 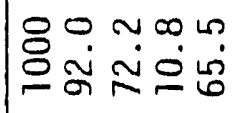 & 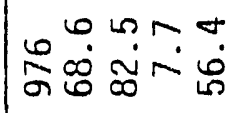 \\
\hline$\infty$ & 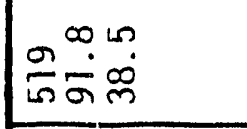 & 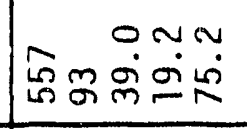 & 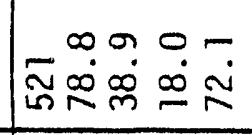 & 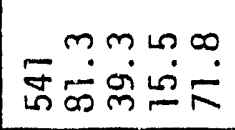 & 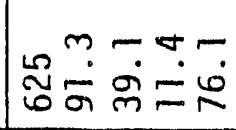 & 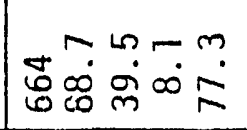 \\
\hline 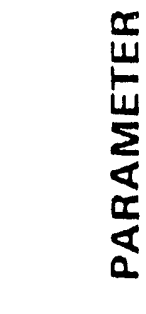 & 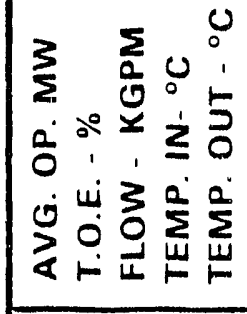 & 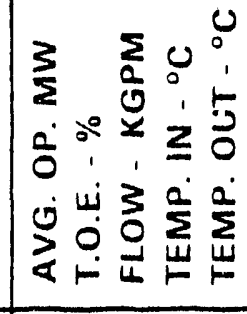 & 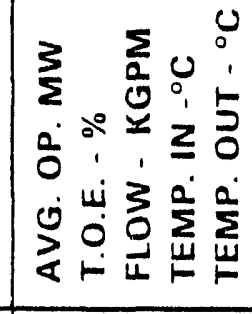 & 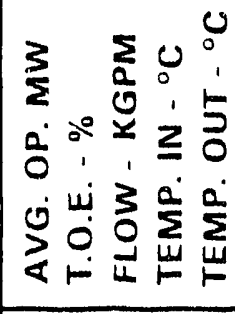 & 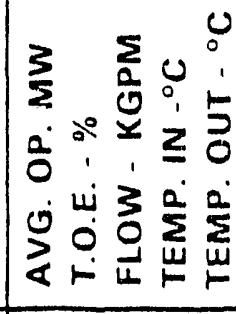 & 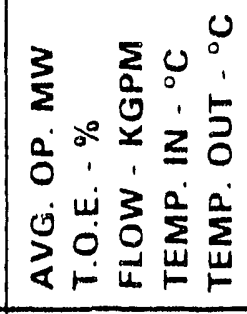 \\
\hline$\frac{\omega}{\delta}$ & $\stackrel{\rho}{\stackrel{\rho}{2}}$ & $\sum_{\infty}^{\infty}$ & $\frac{\rho}{\sigma}$ & 㿣 & 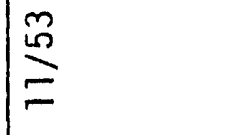 & 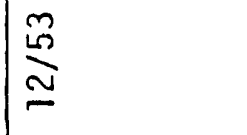 \\
\hline
\end{tabular}




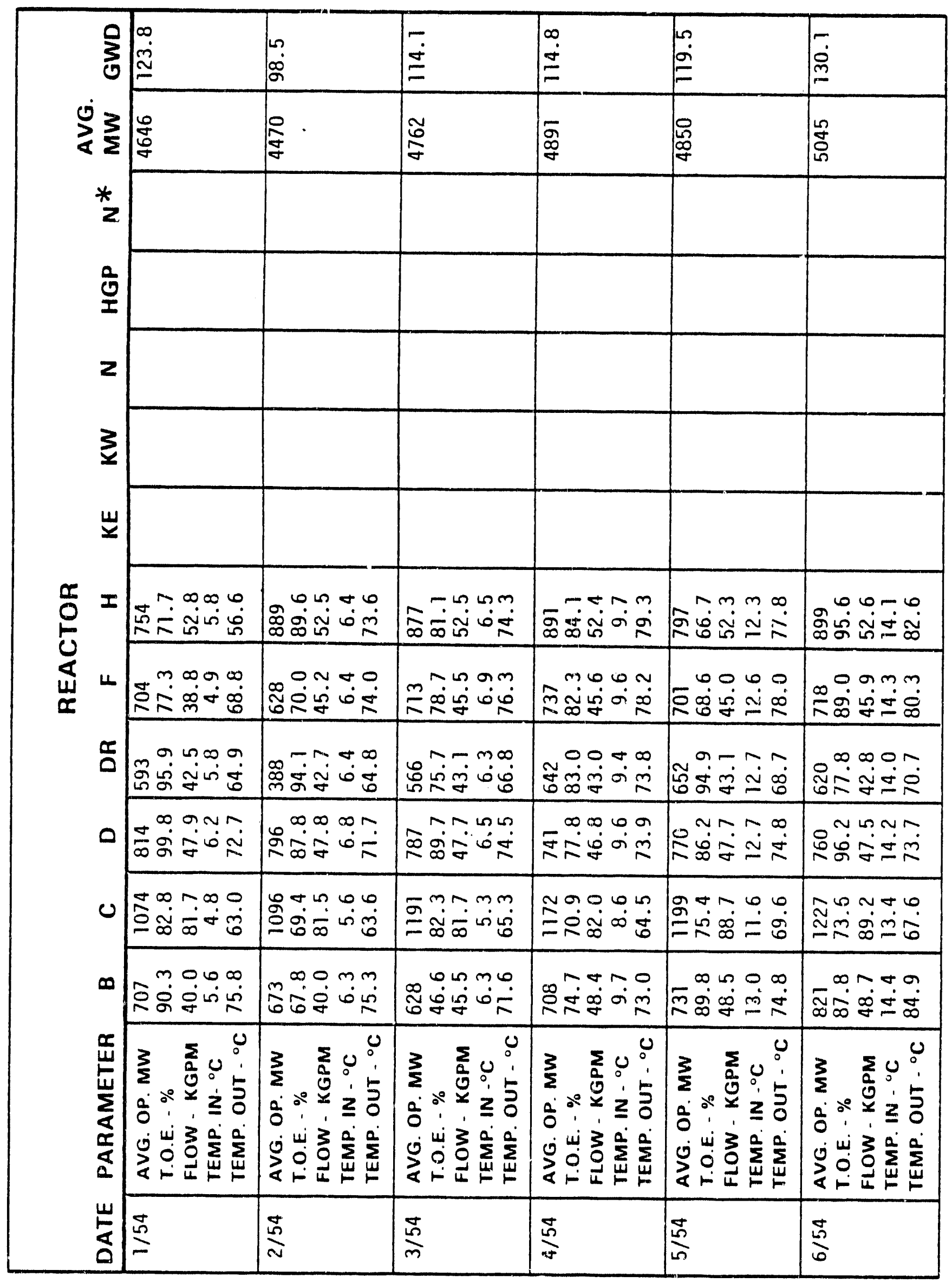




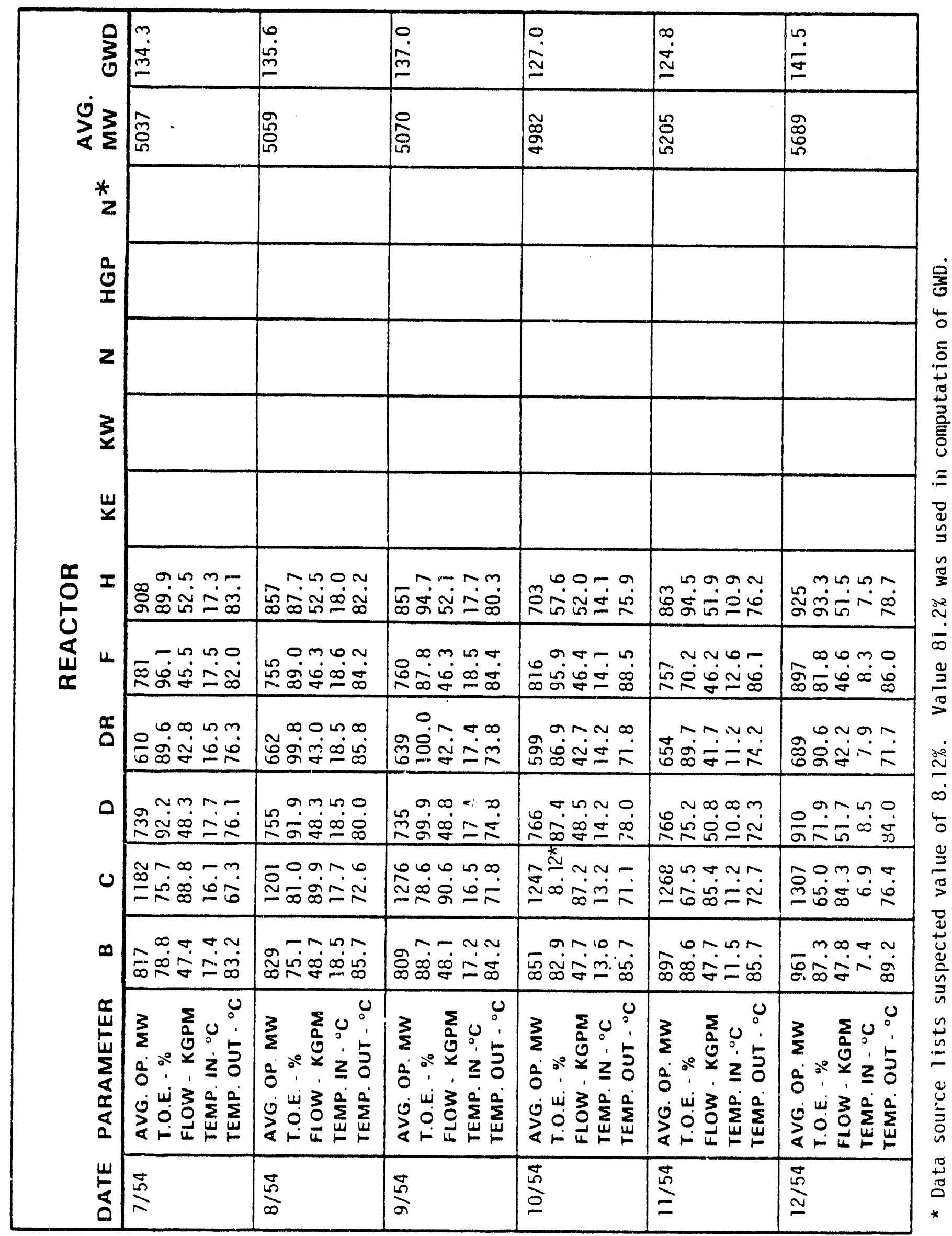




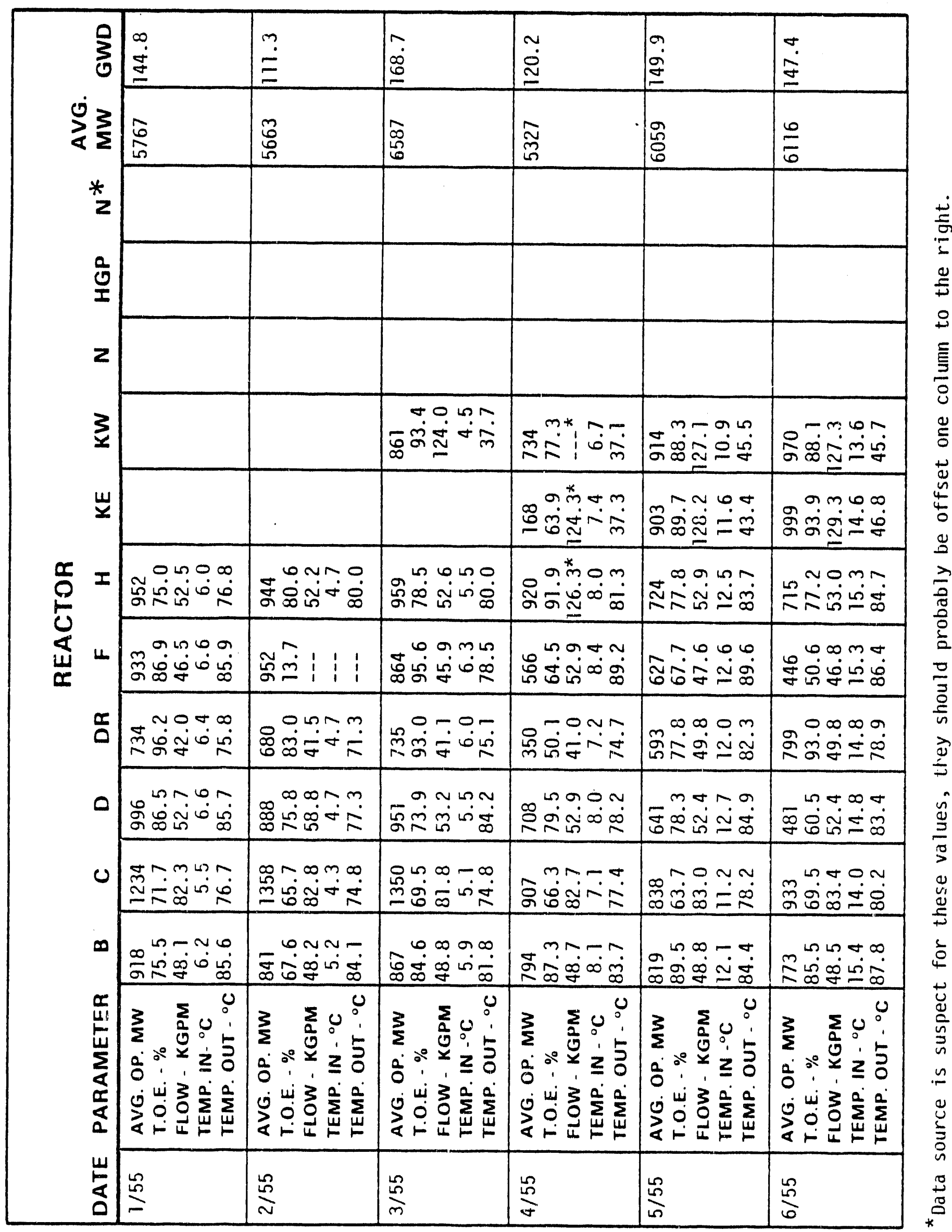




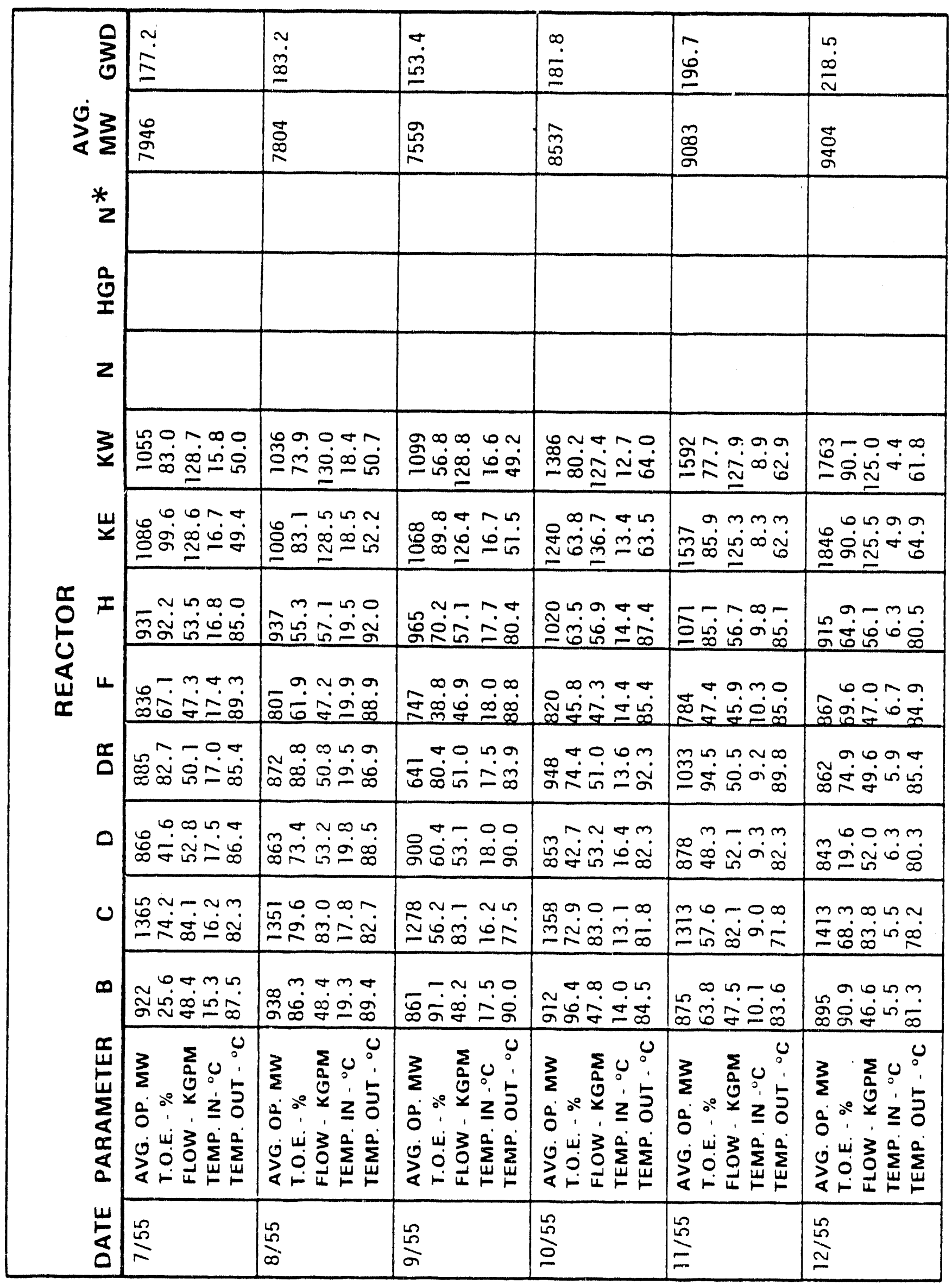




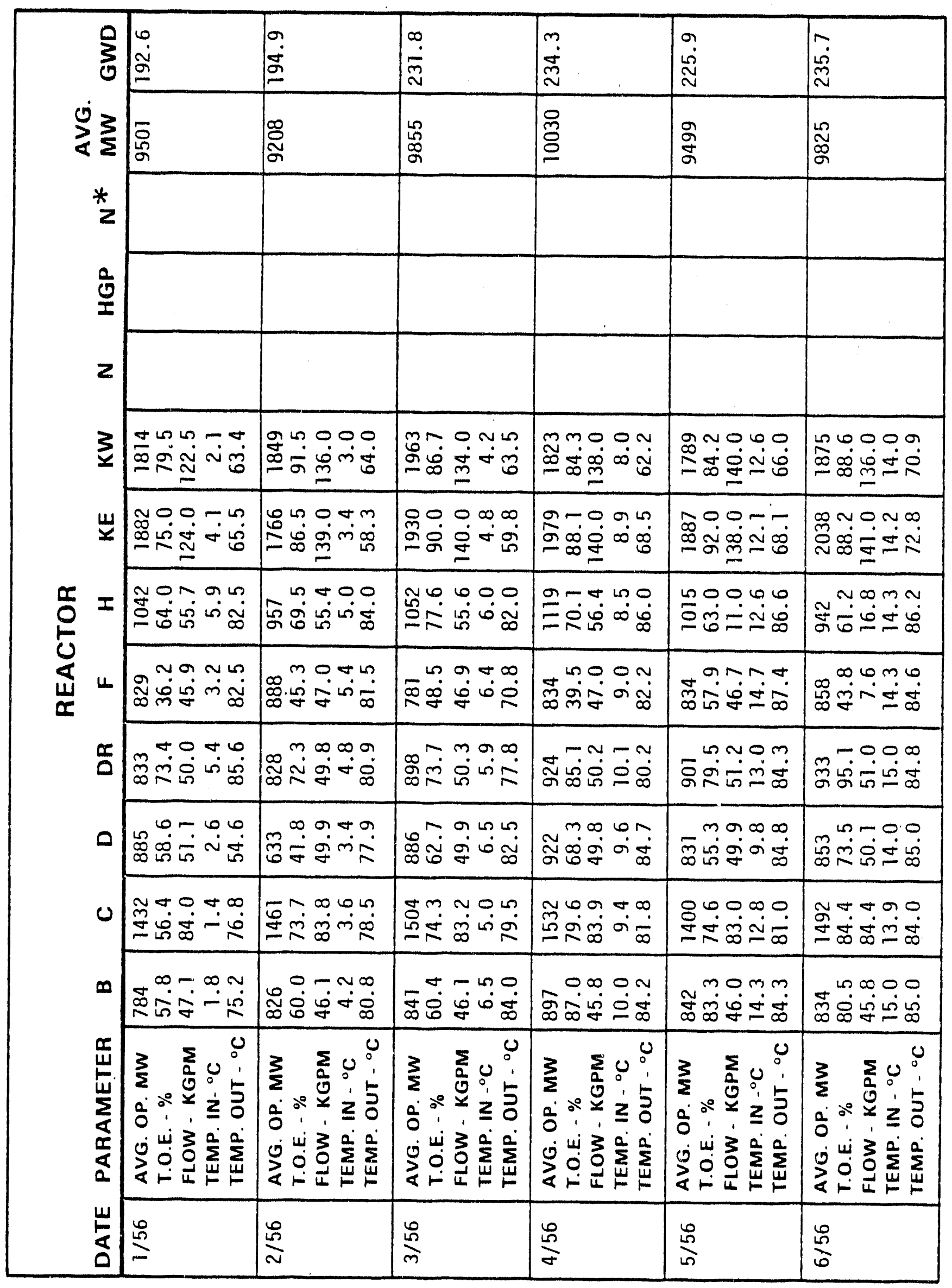




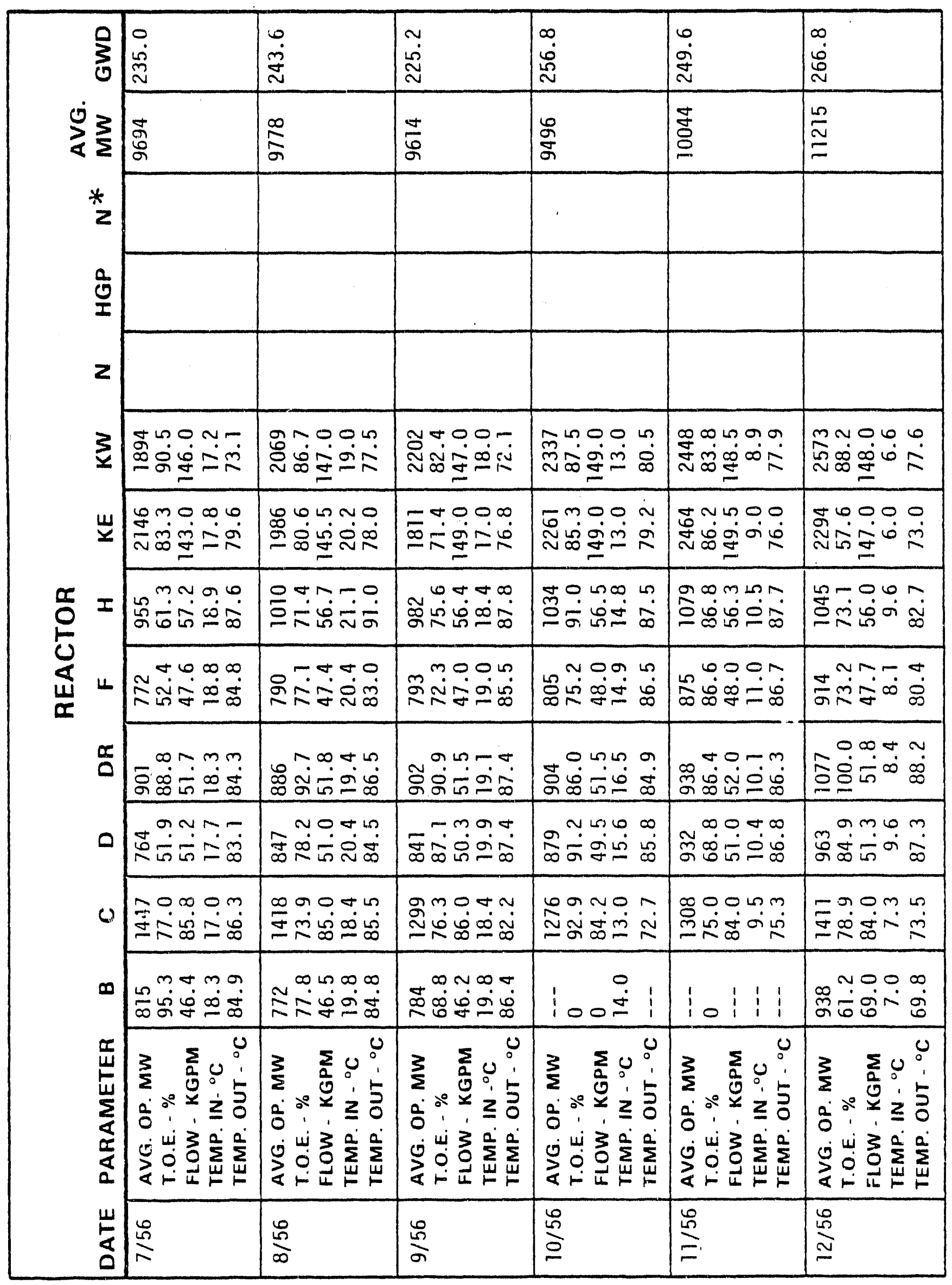




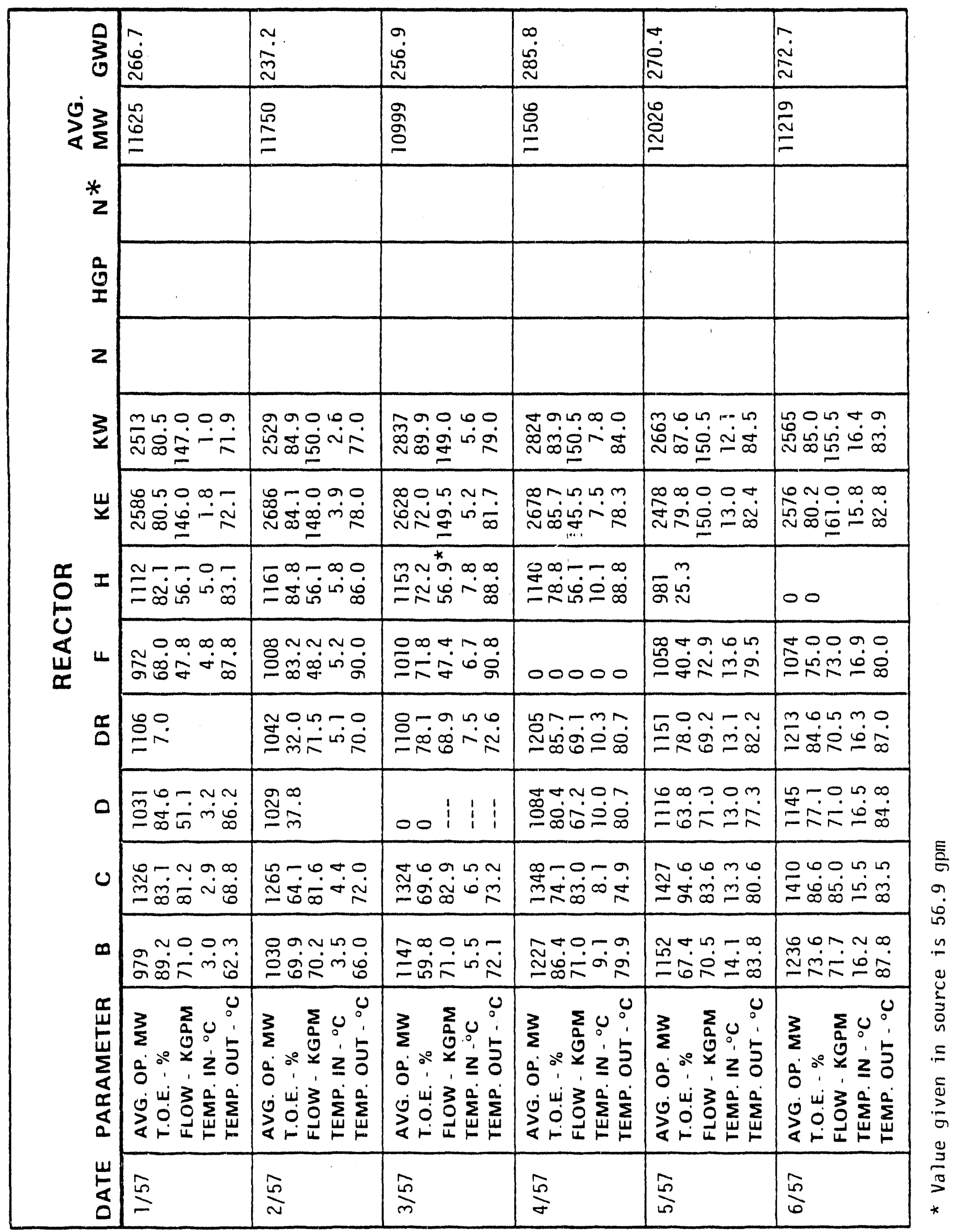




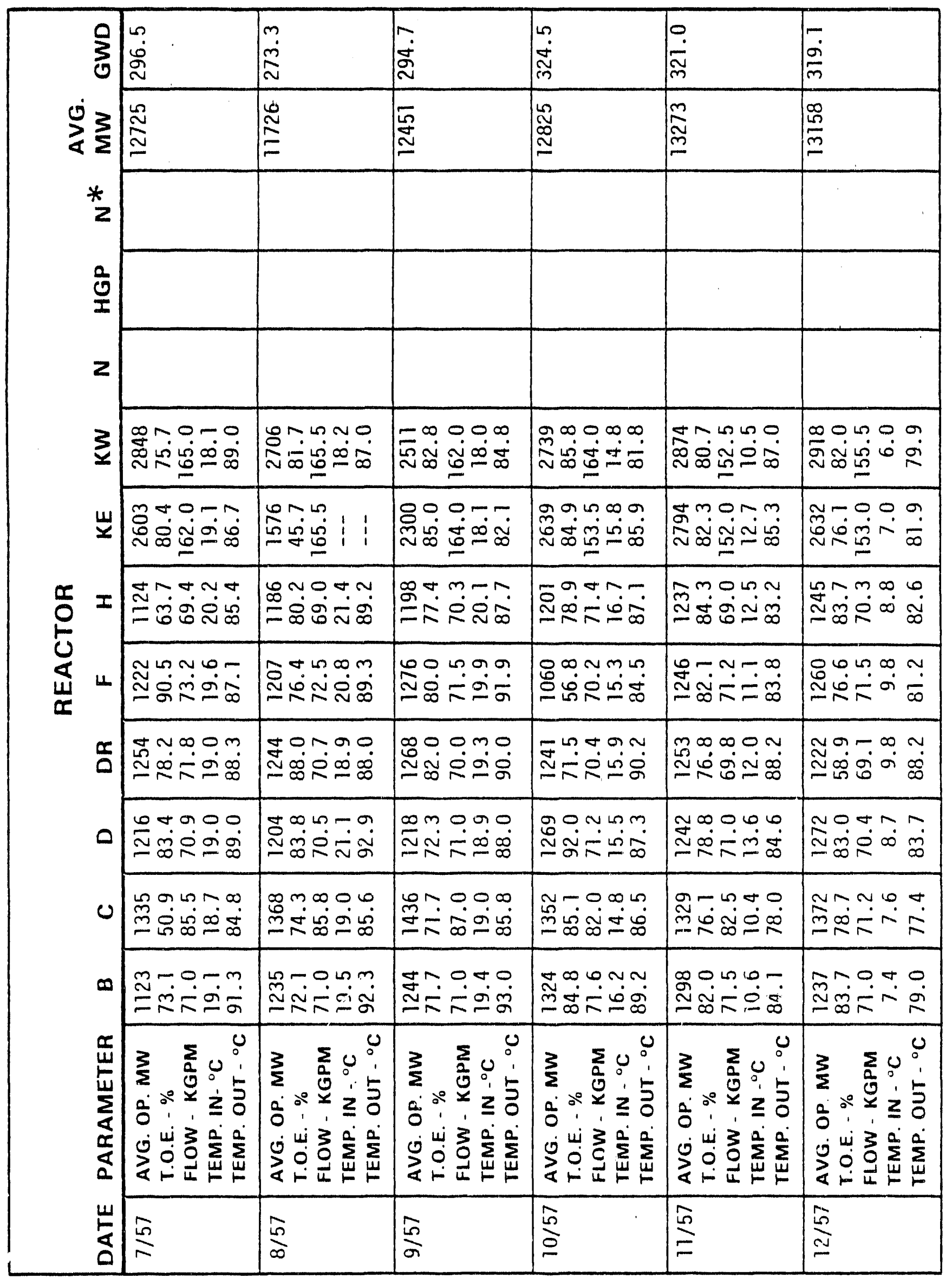




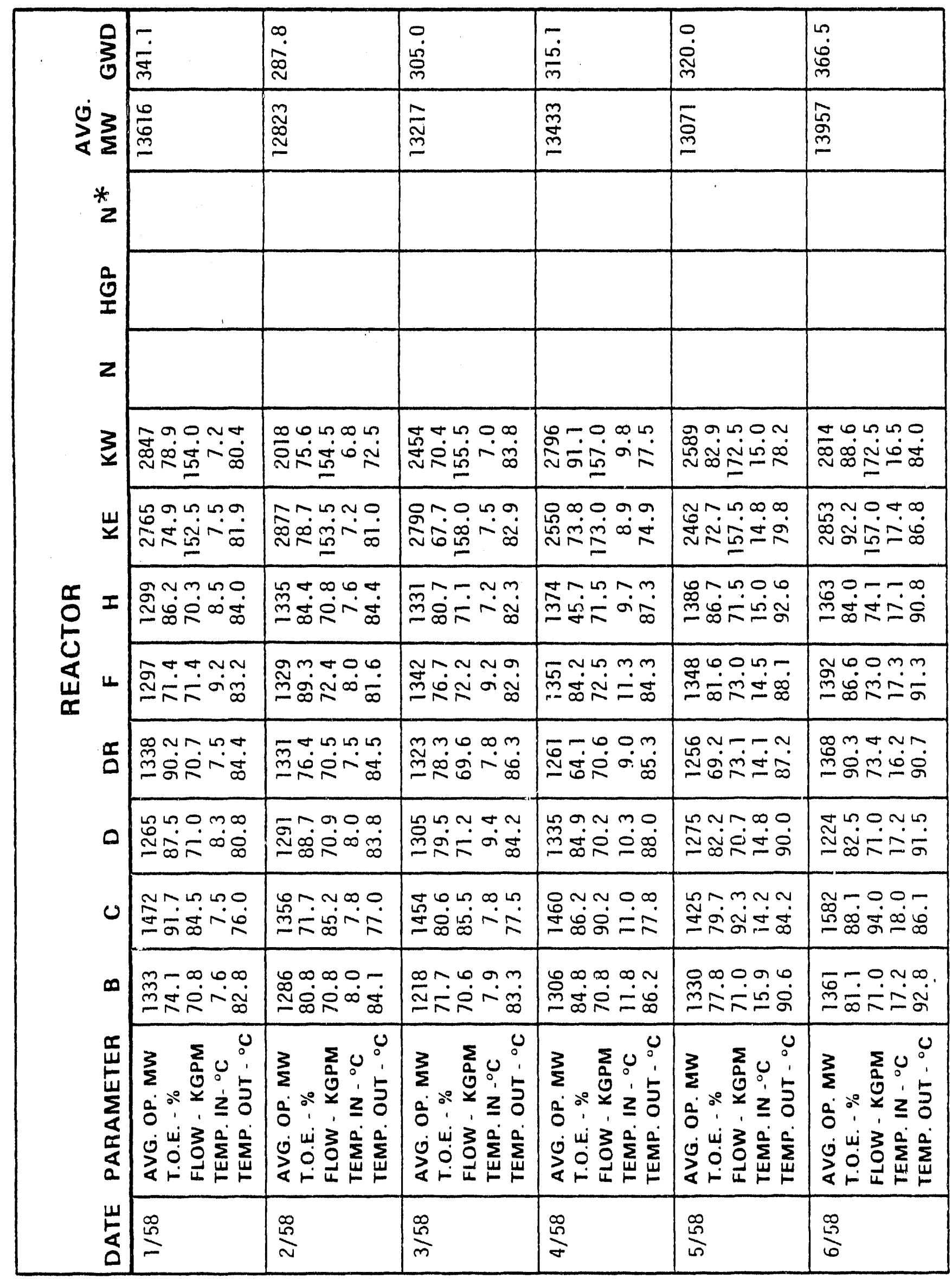




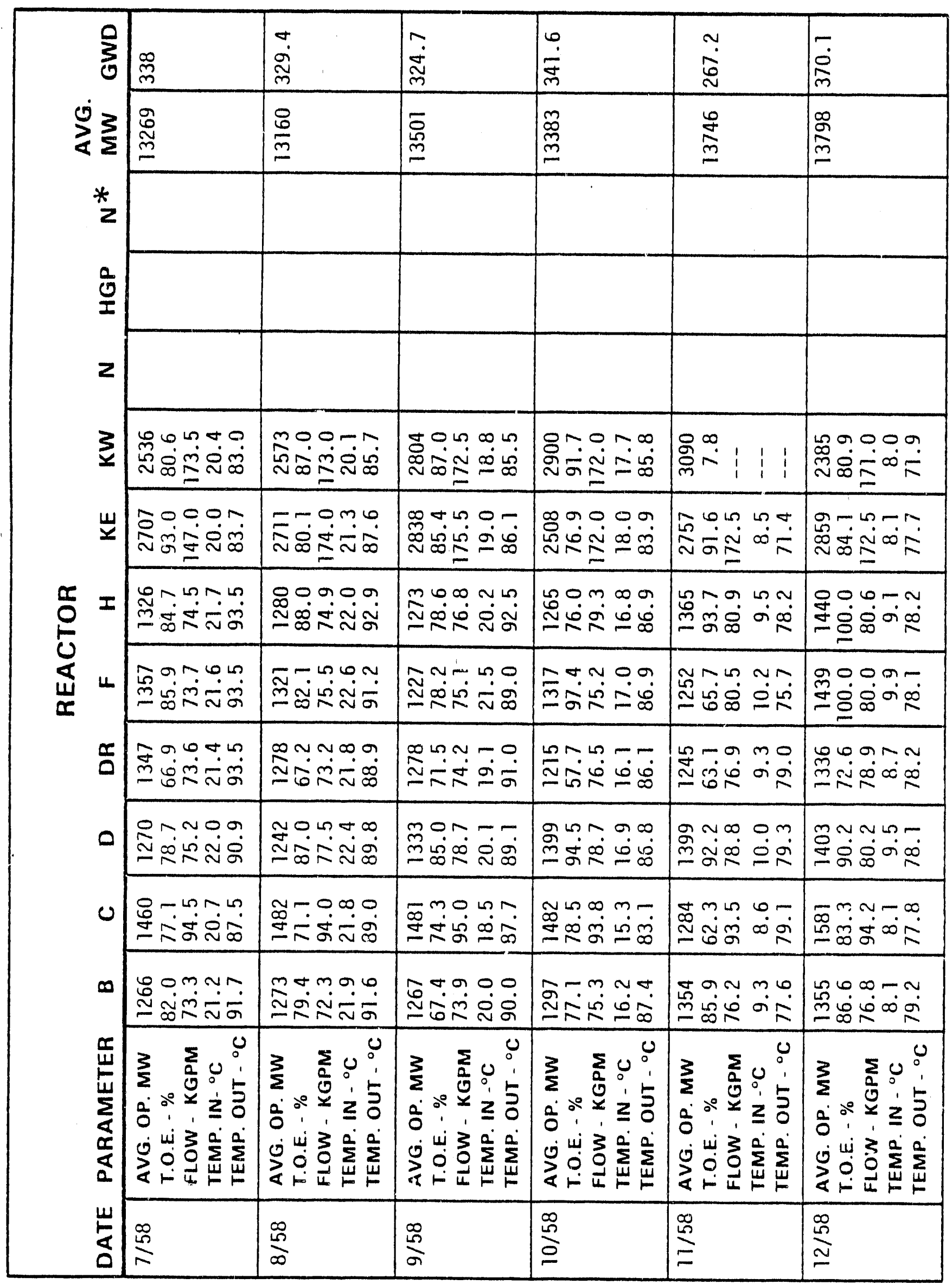




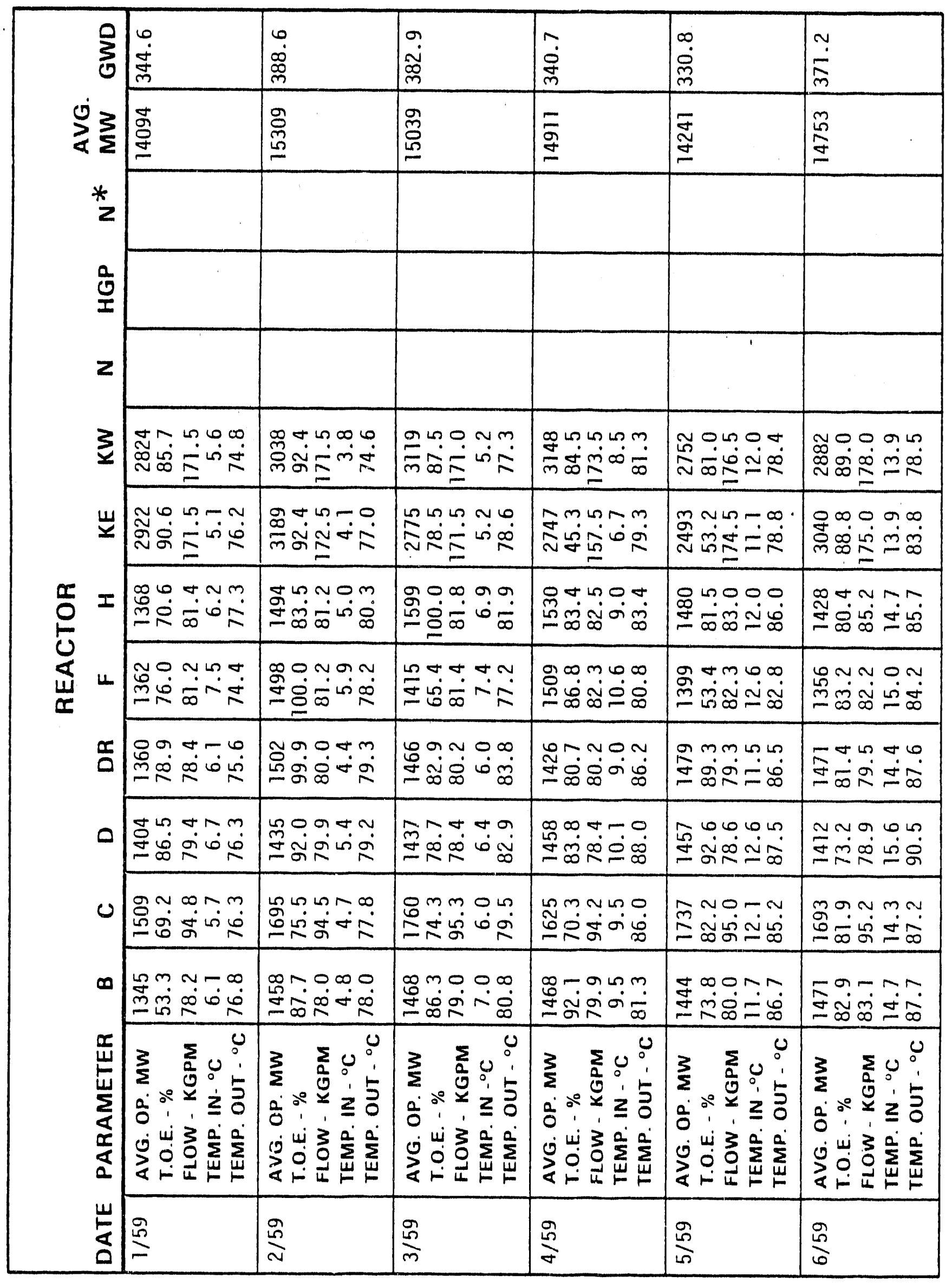




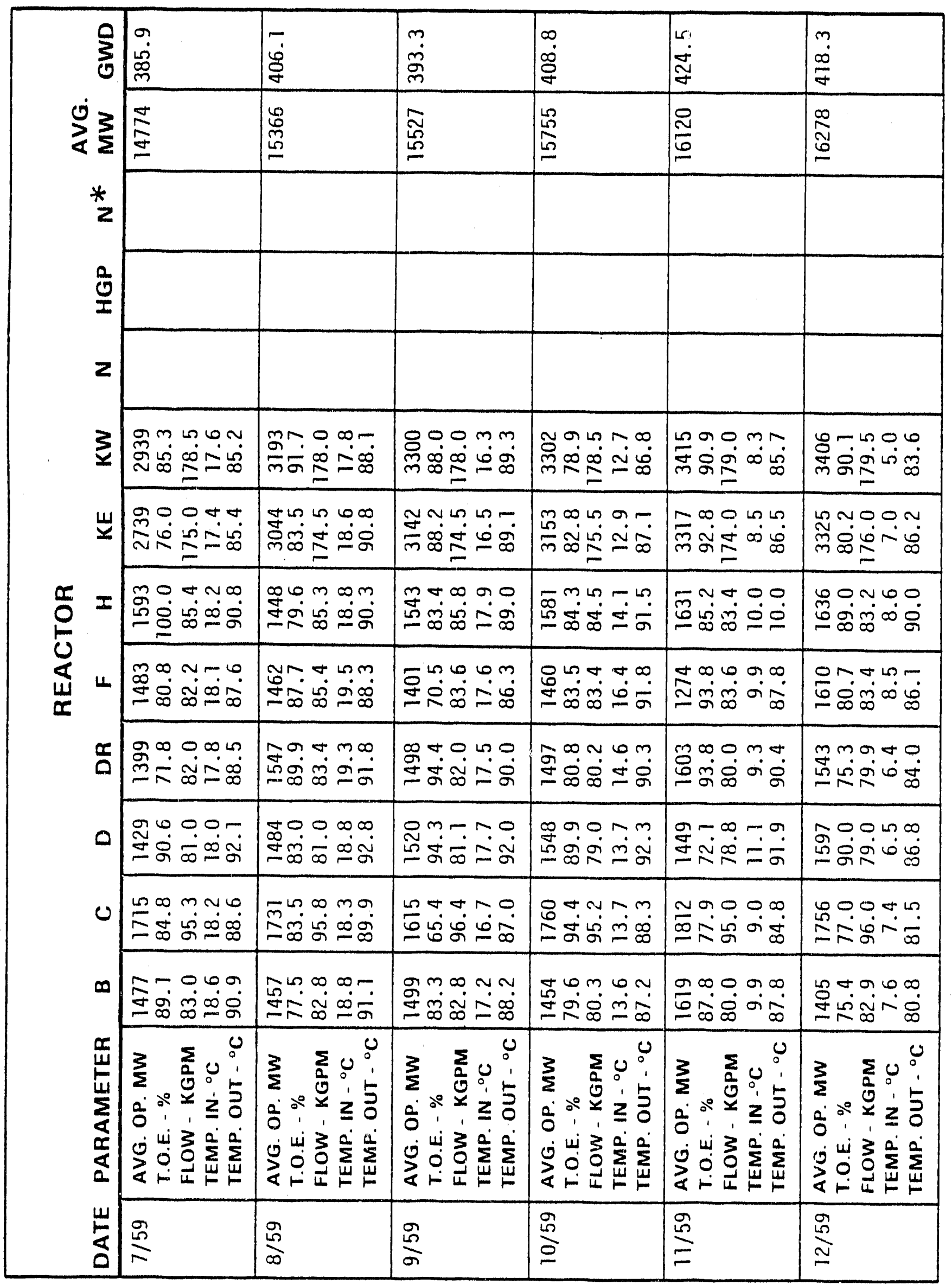




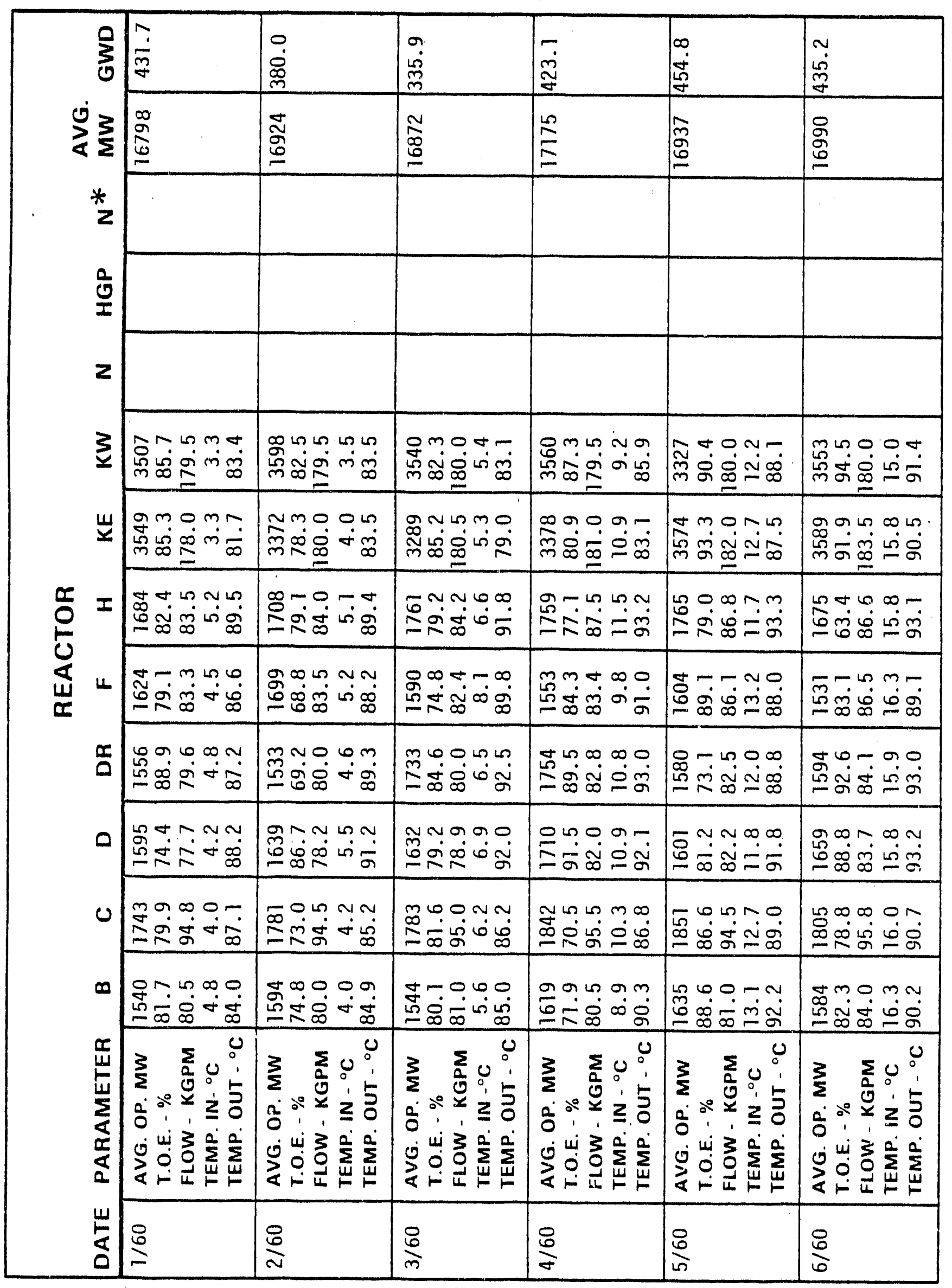




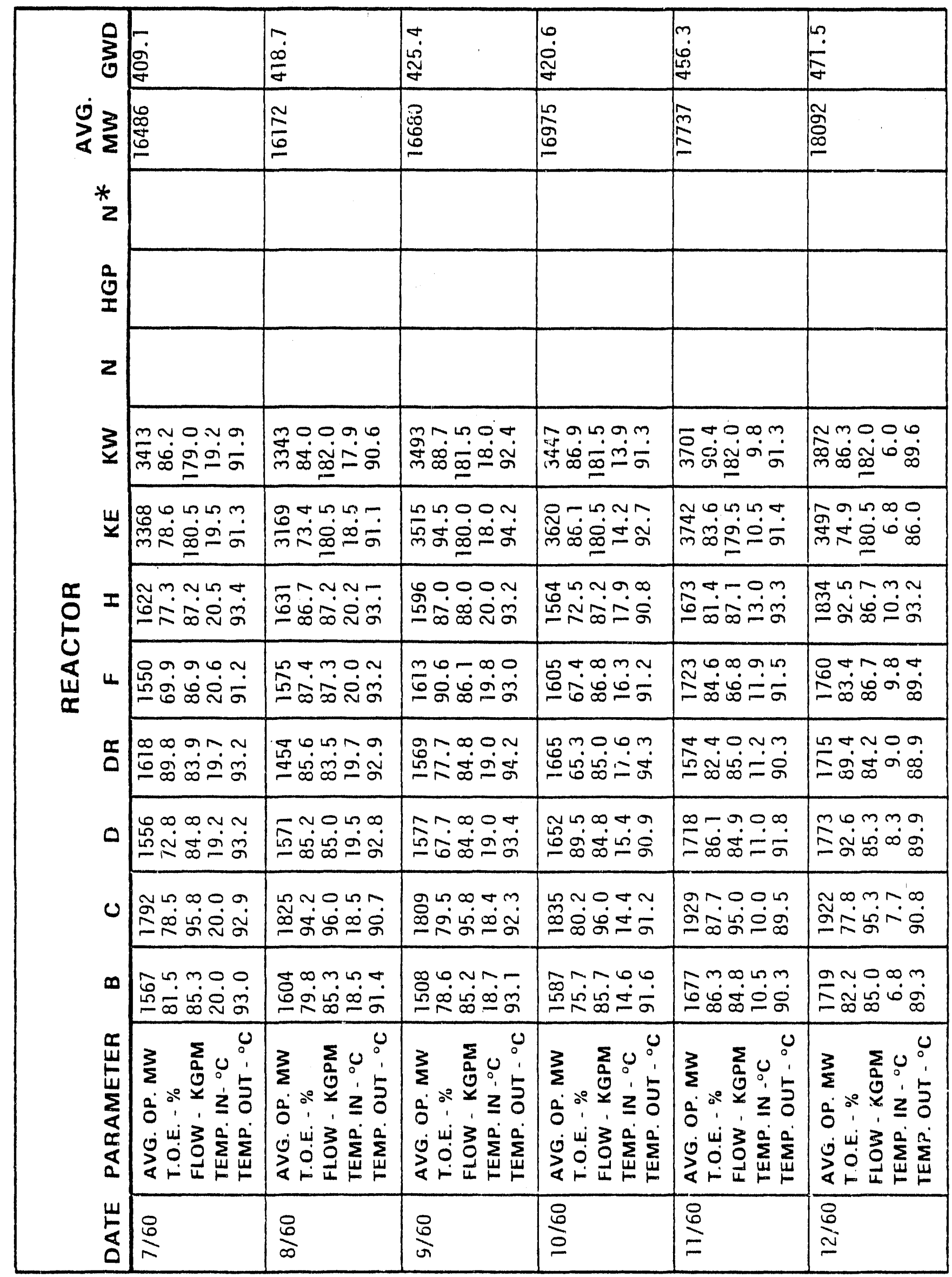




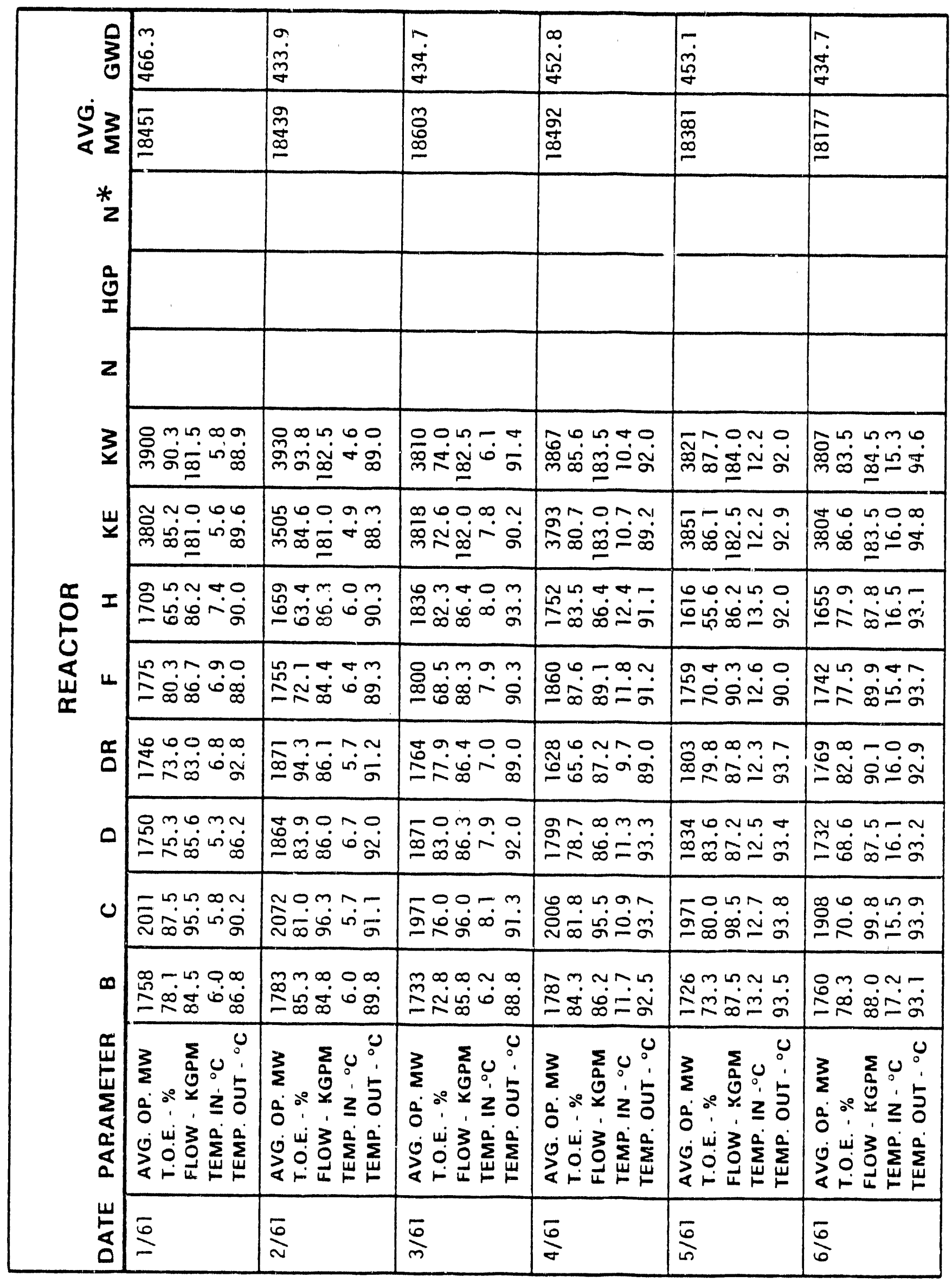




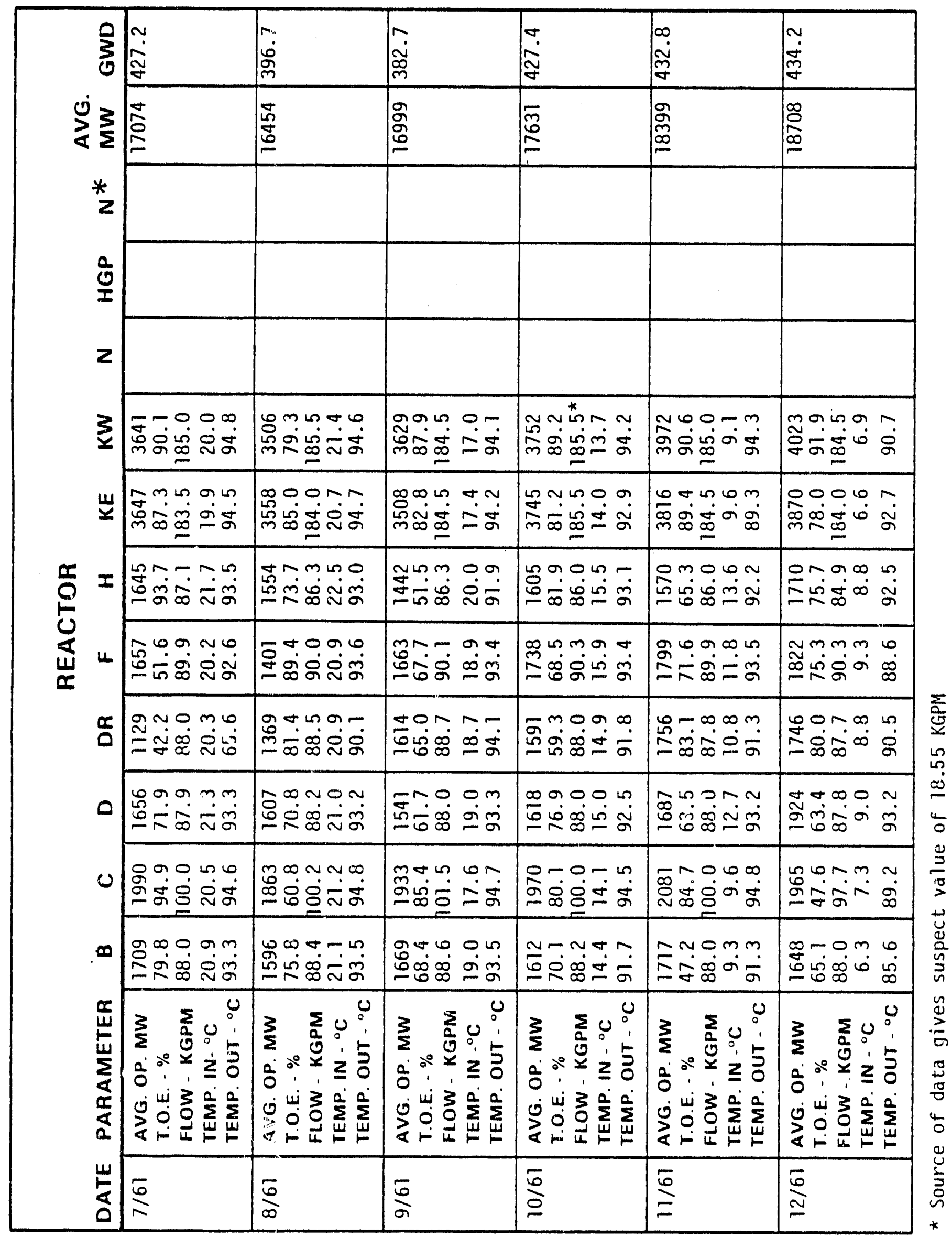




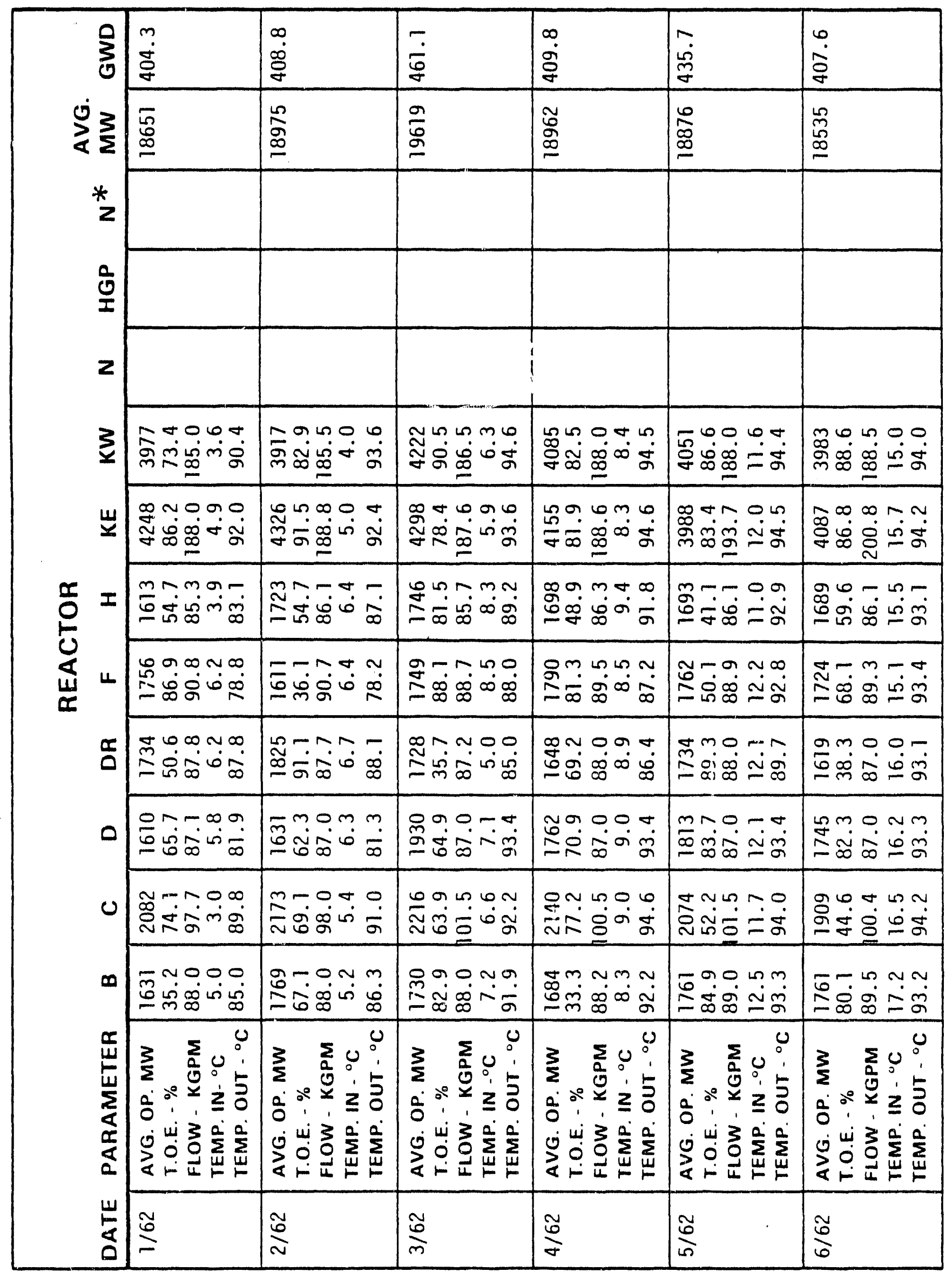




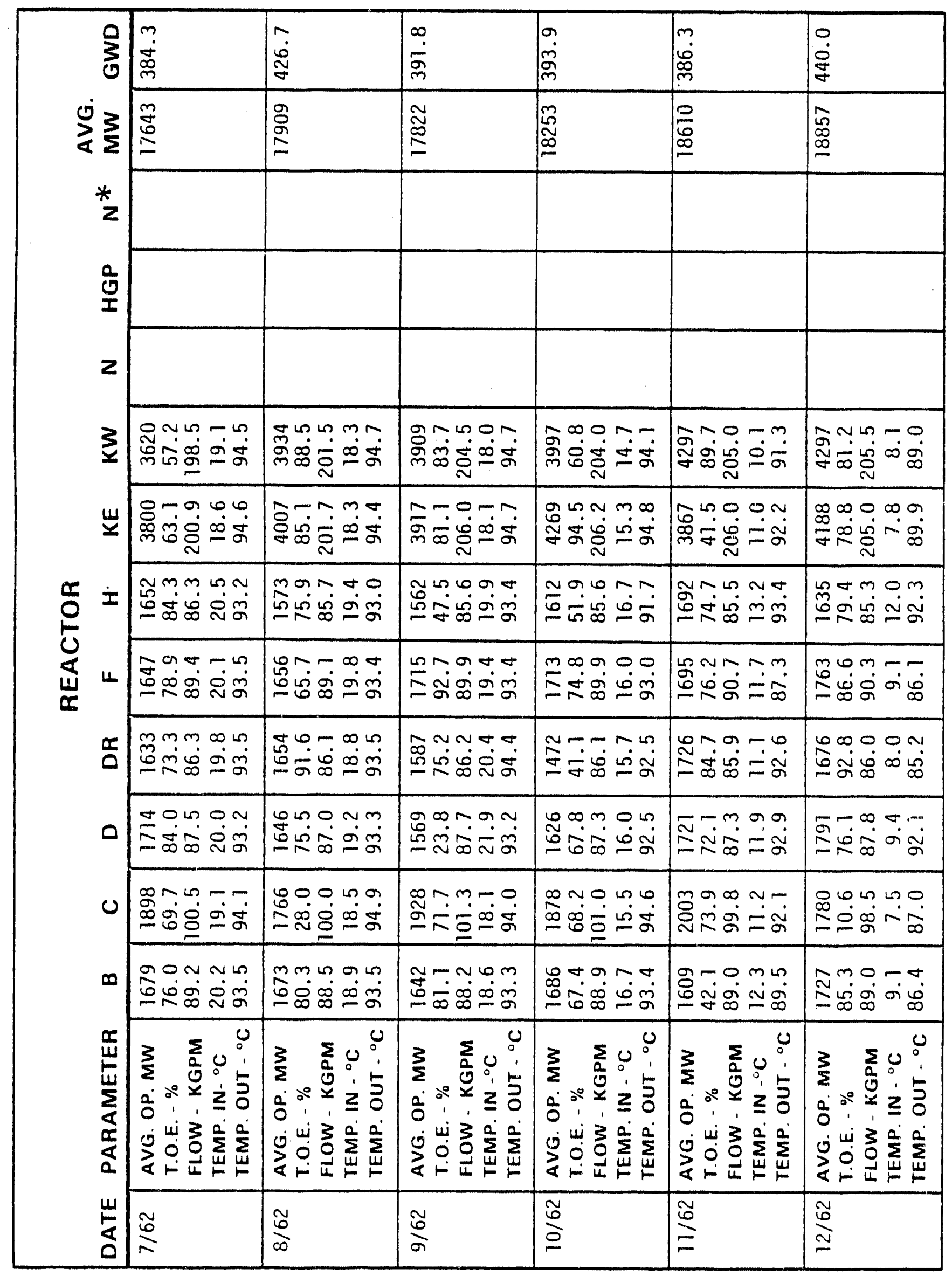




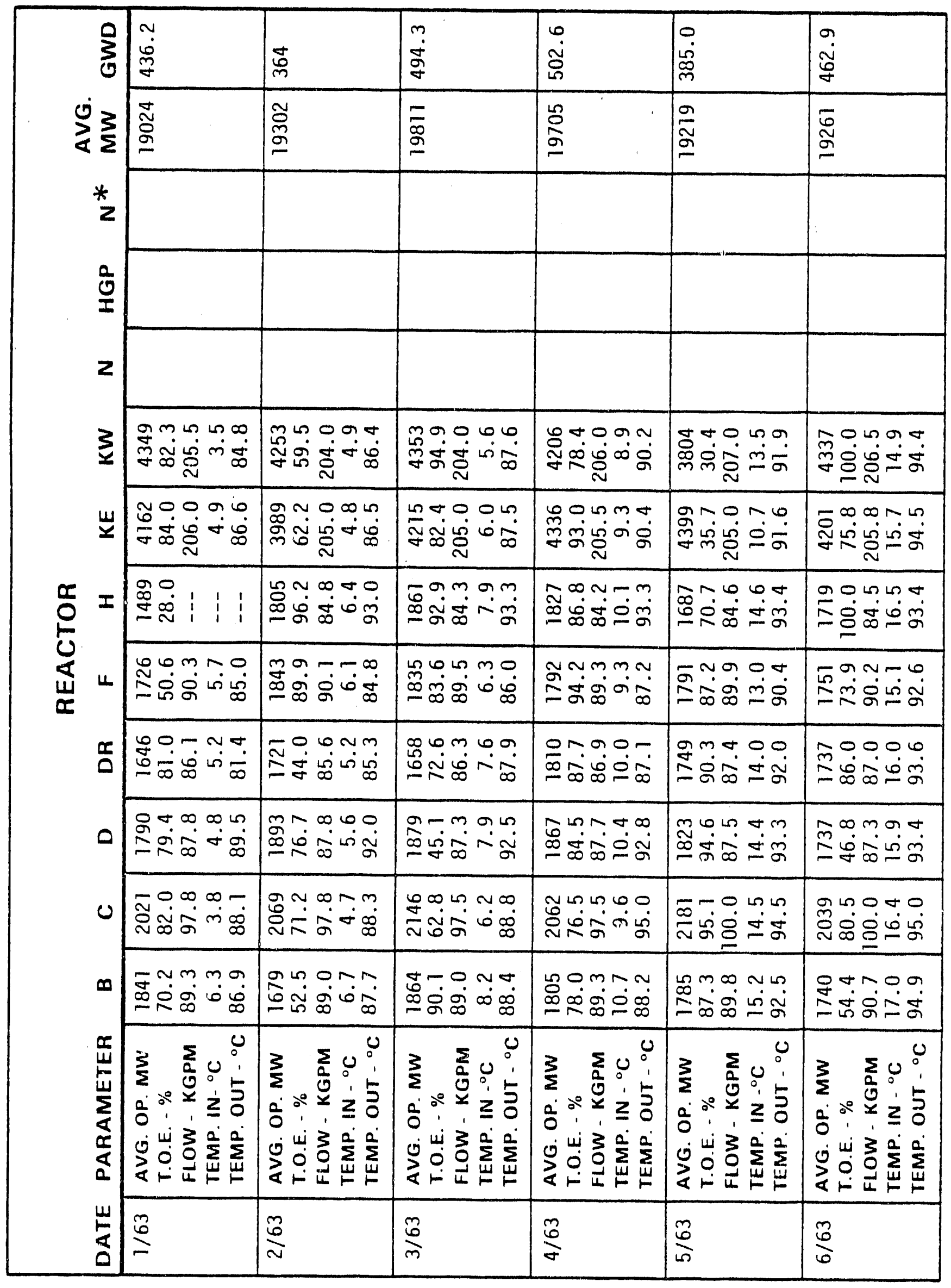




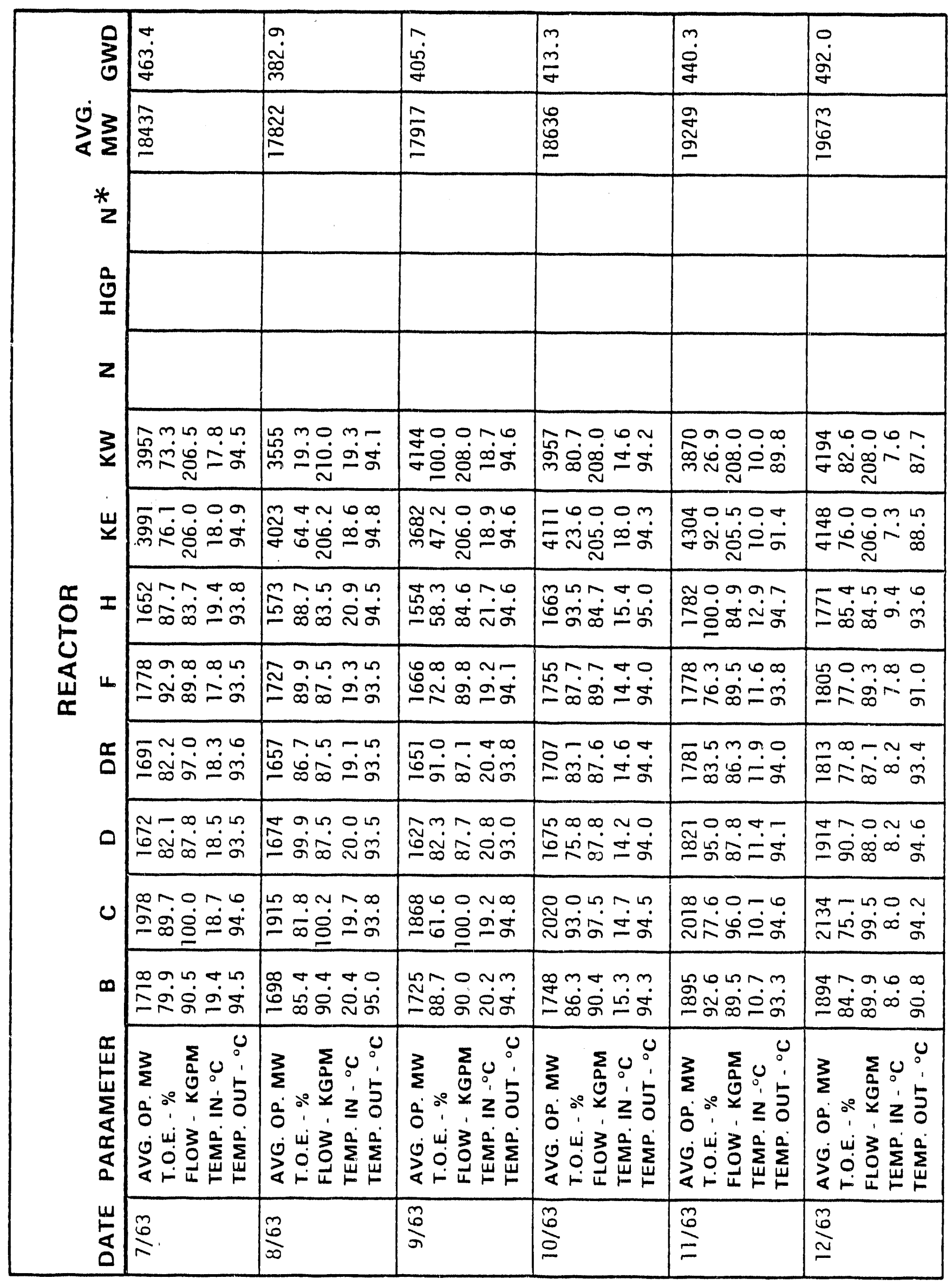




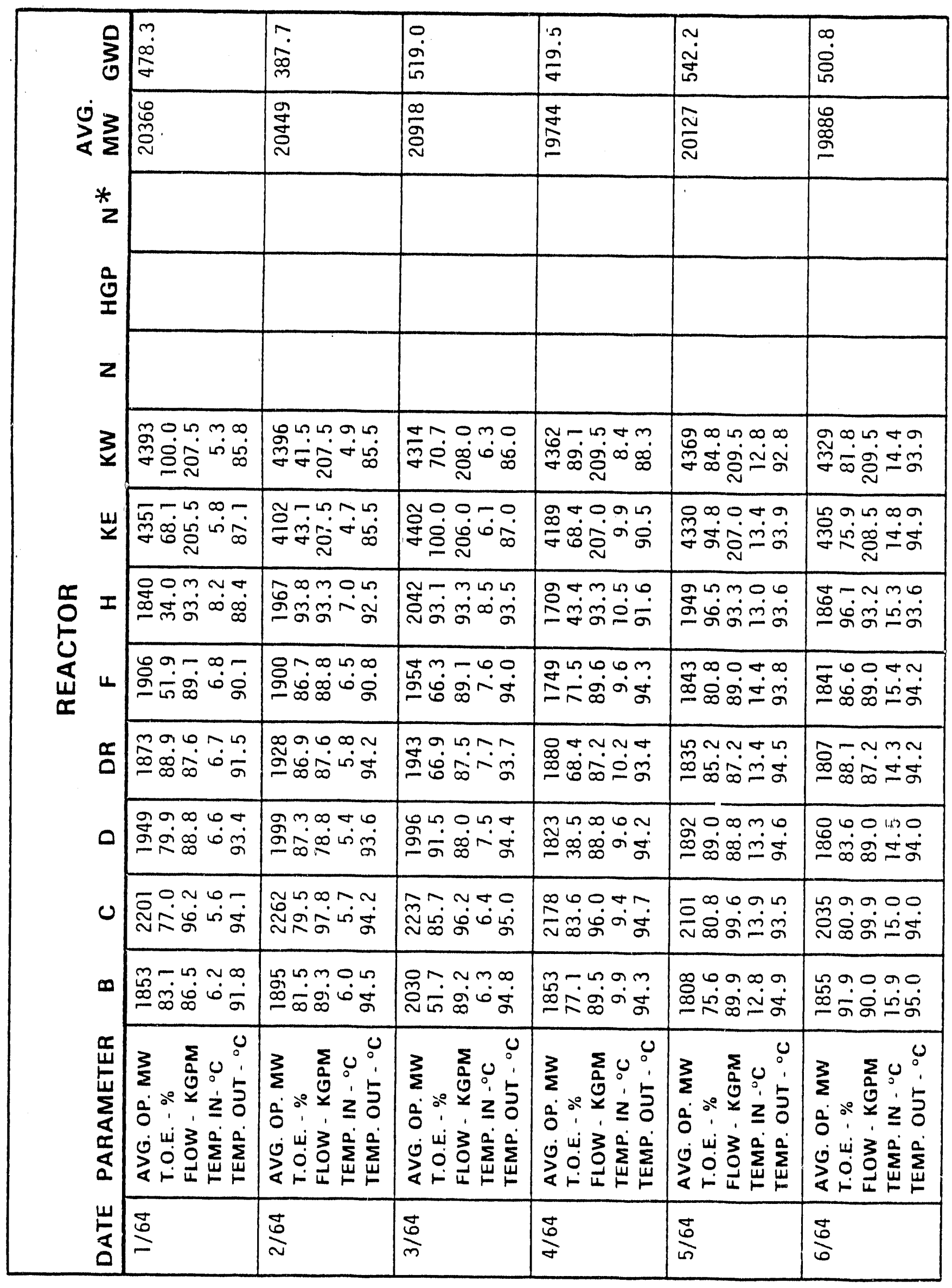




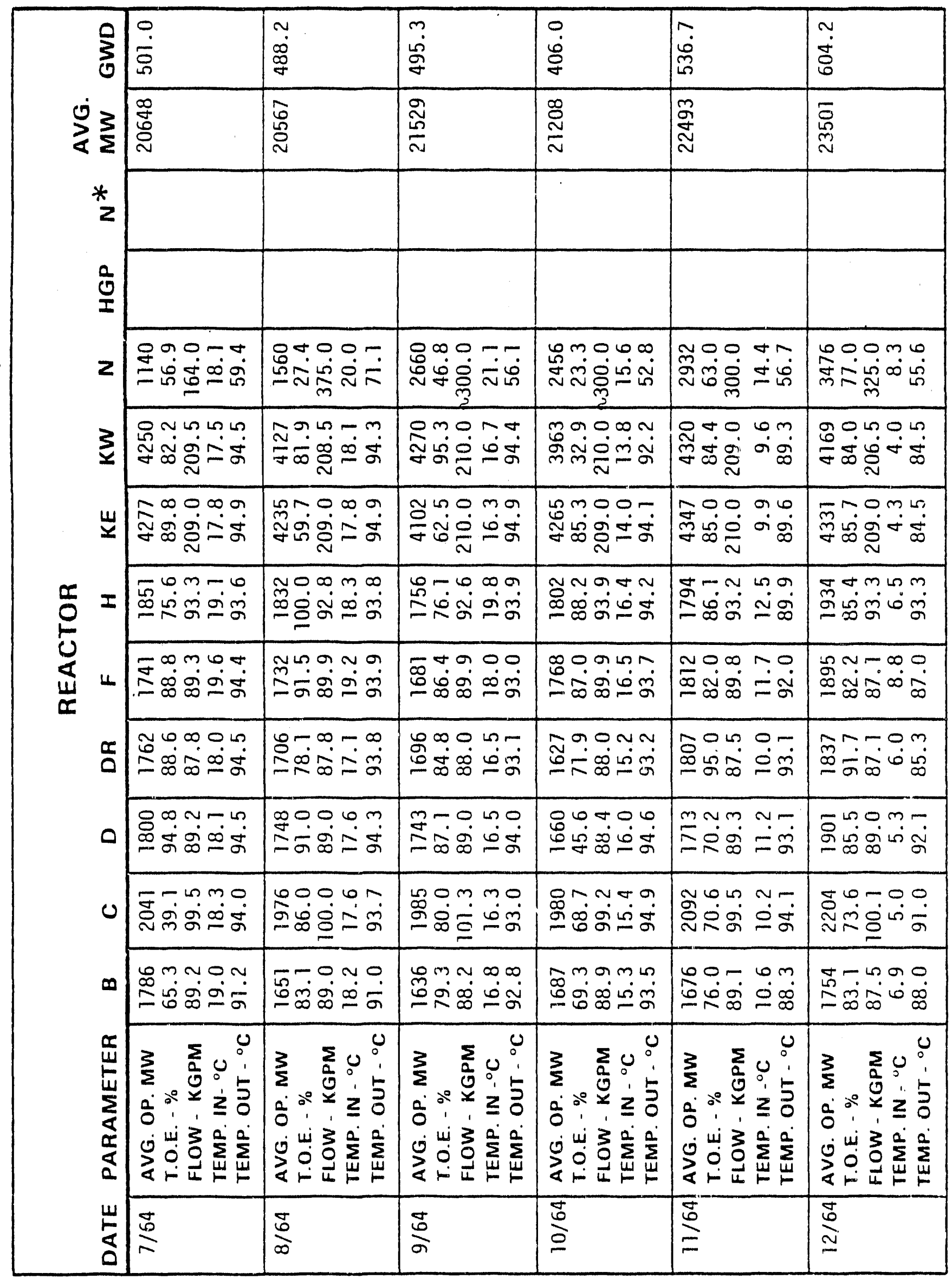




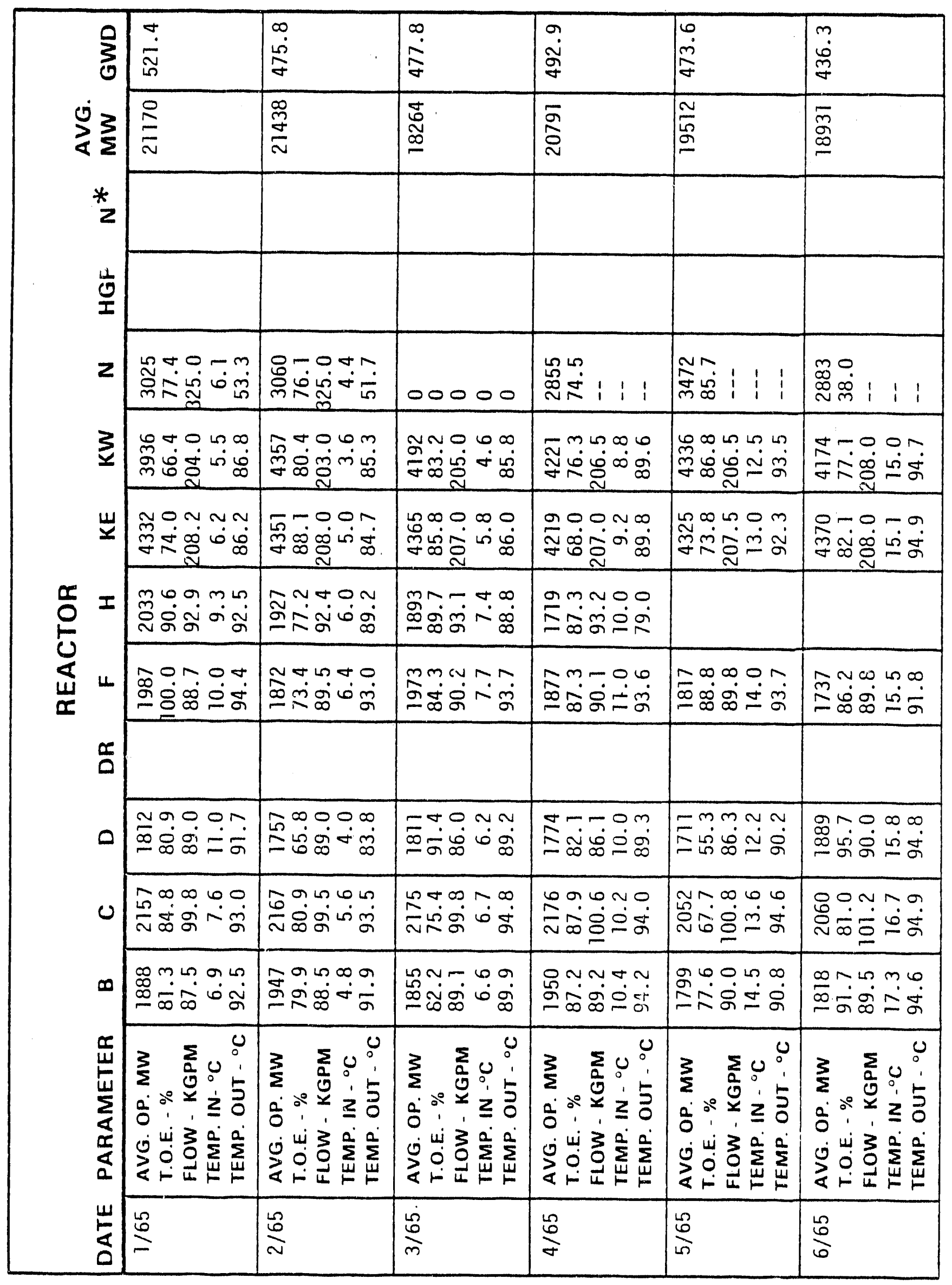




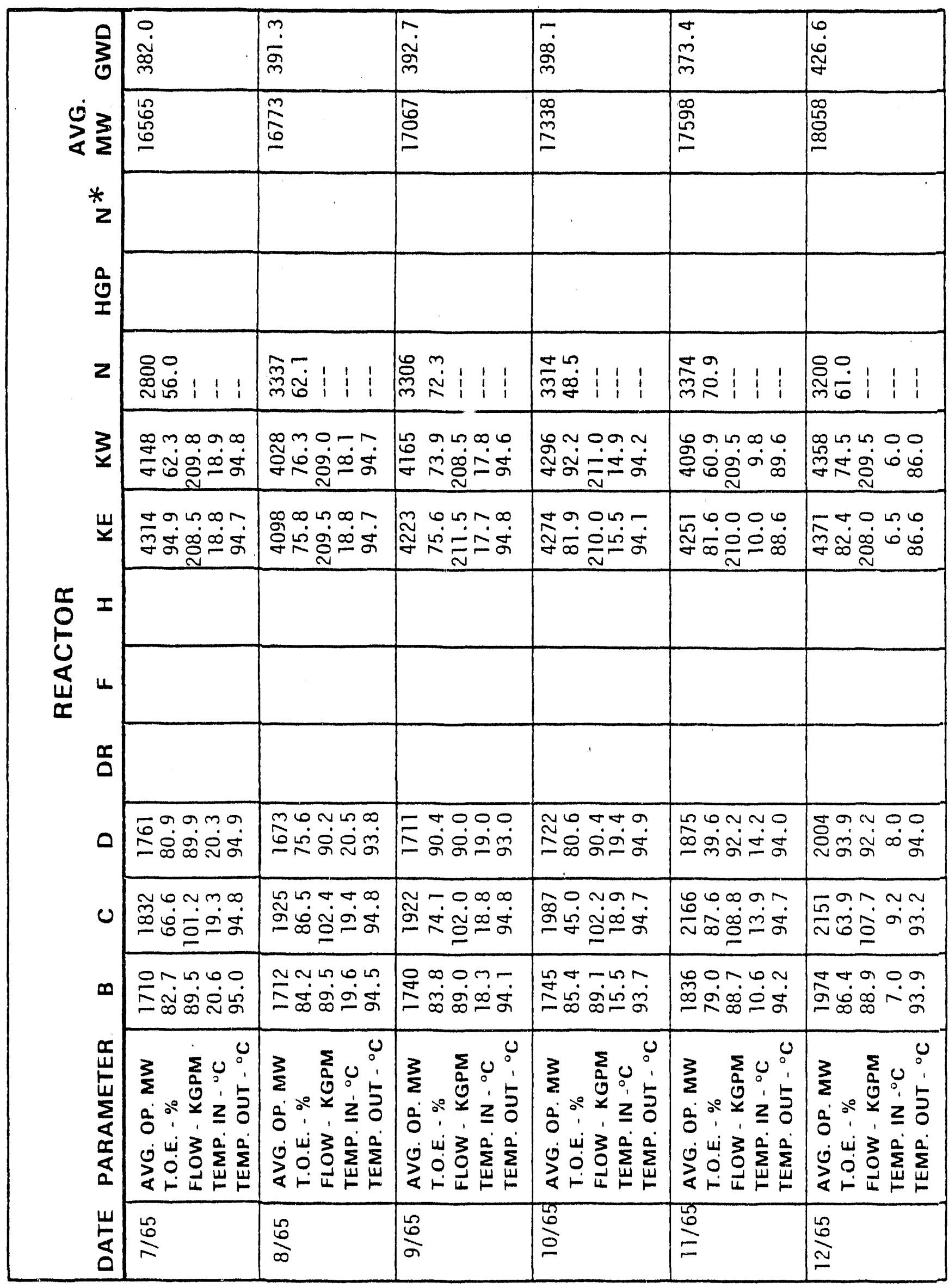




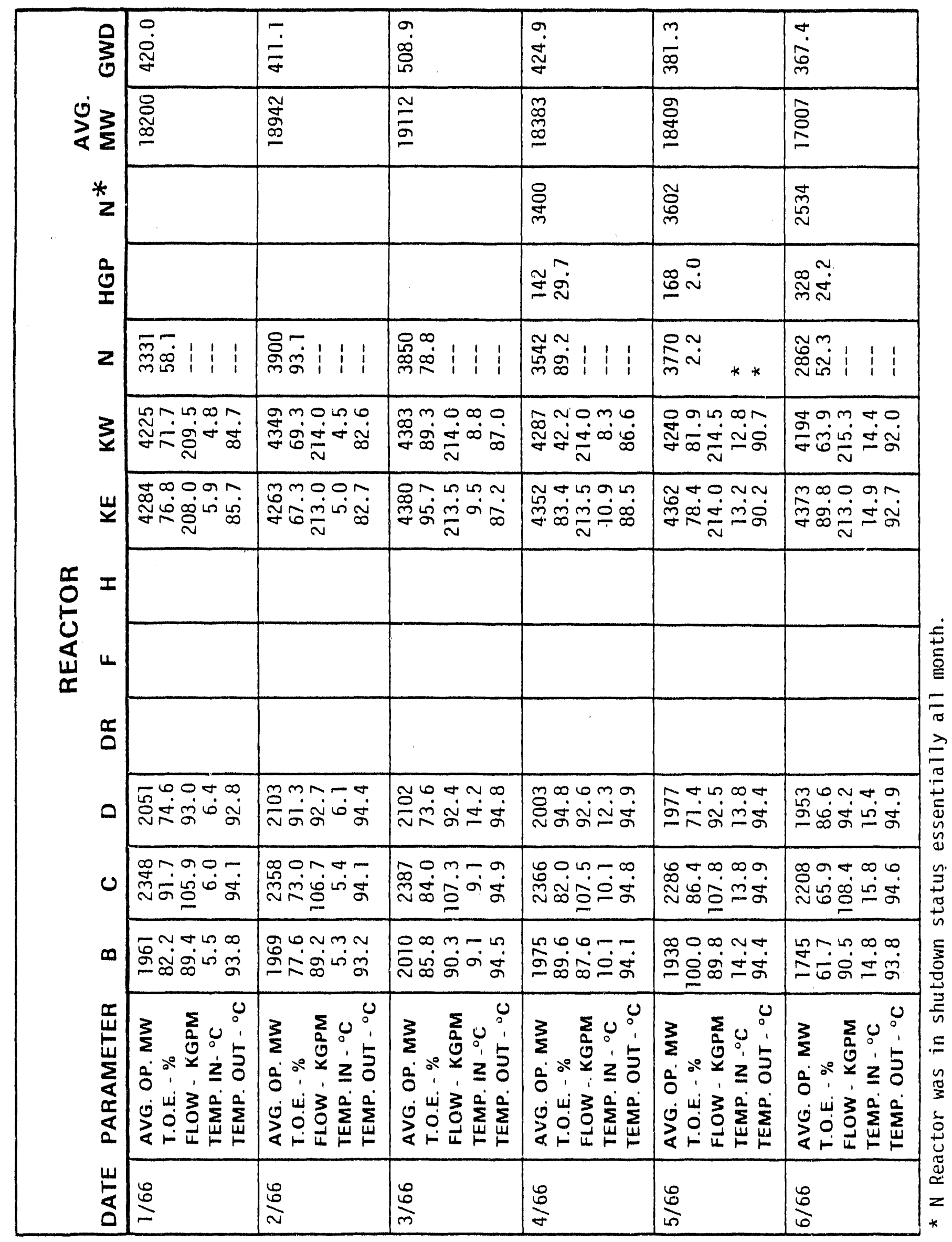




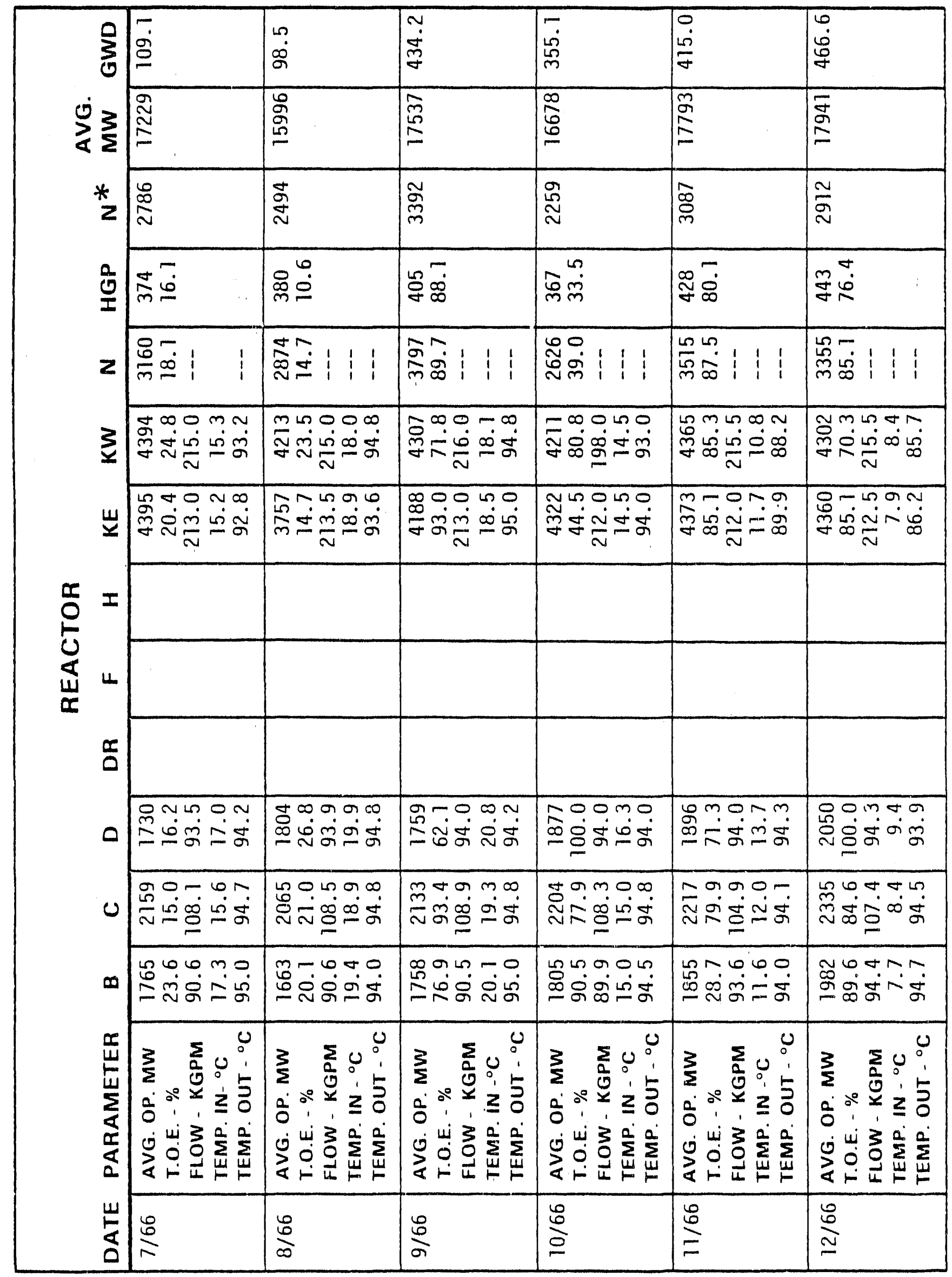




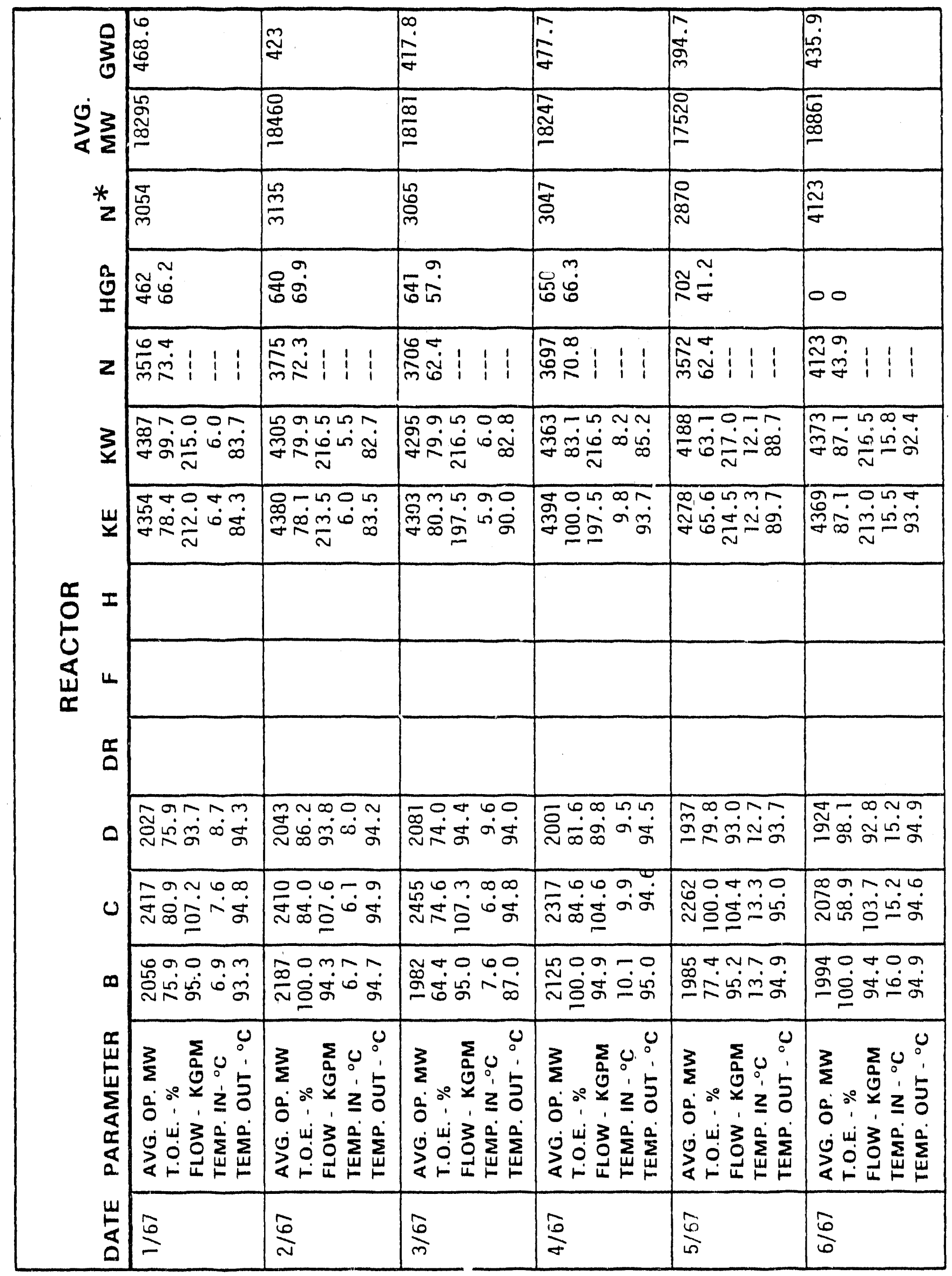




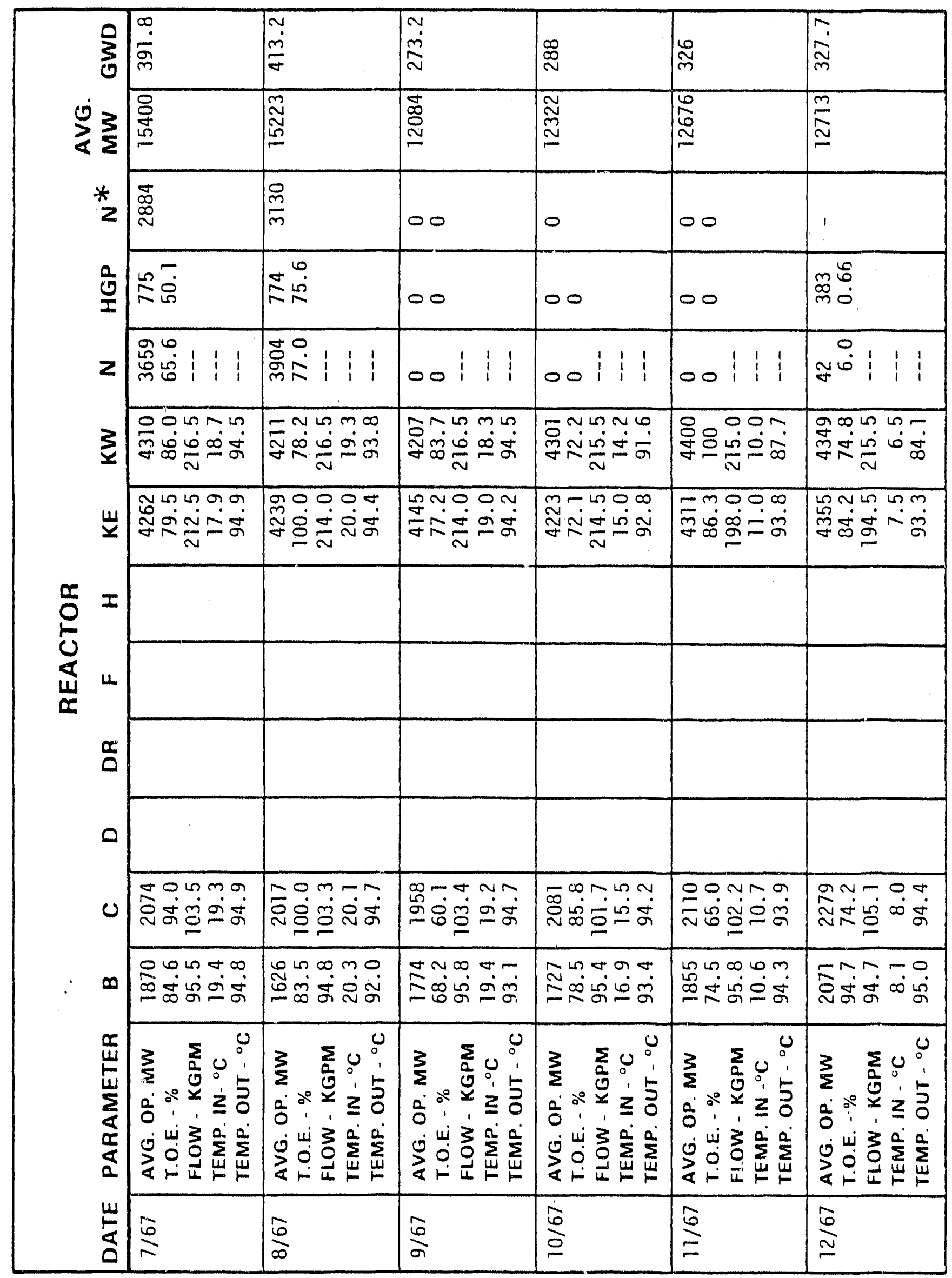




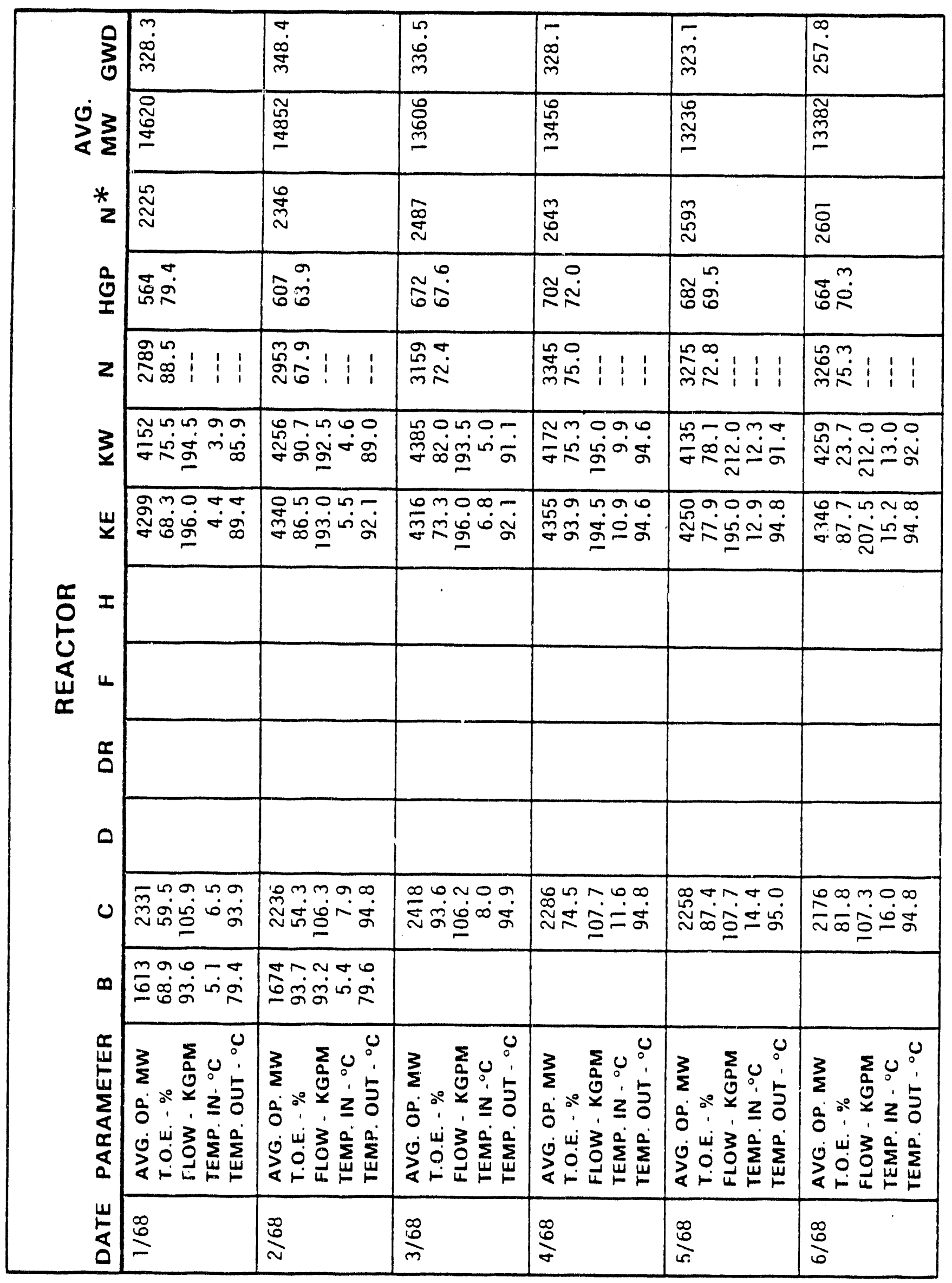




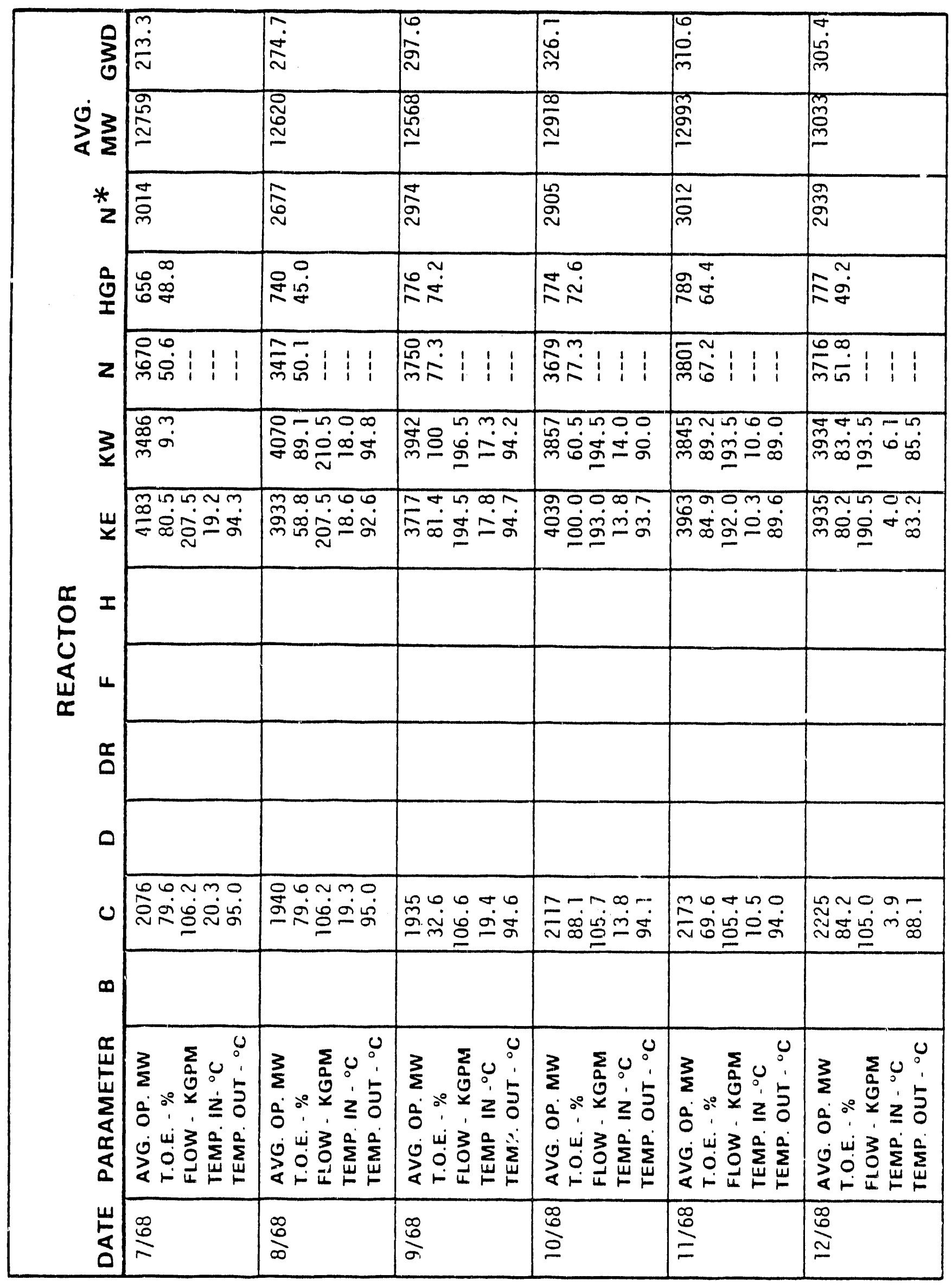




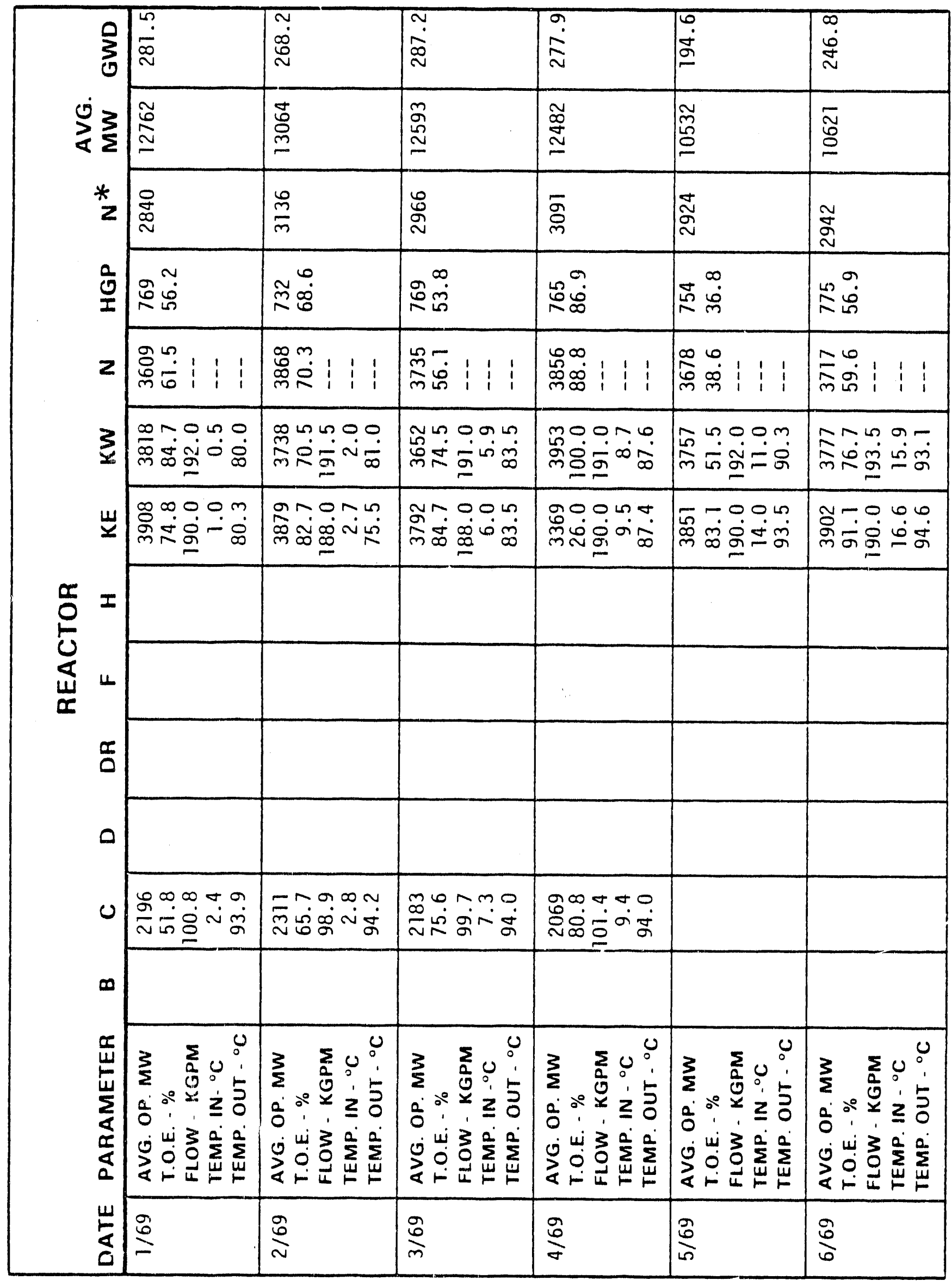




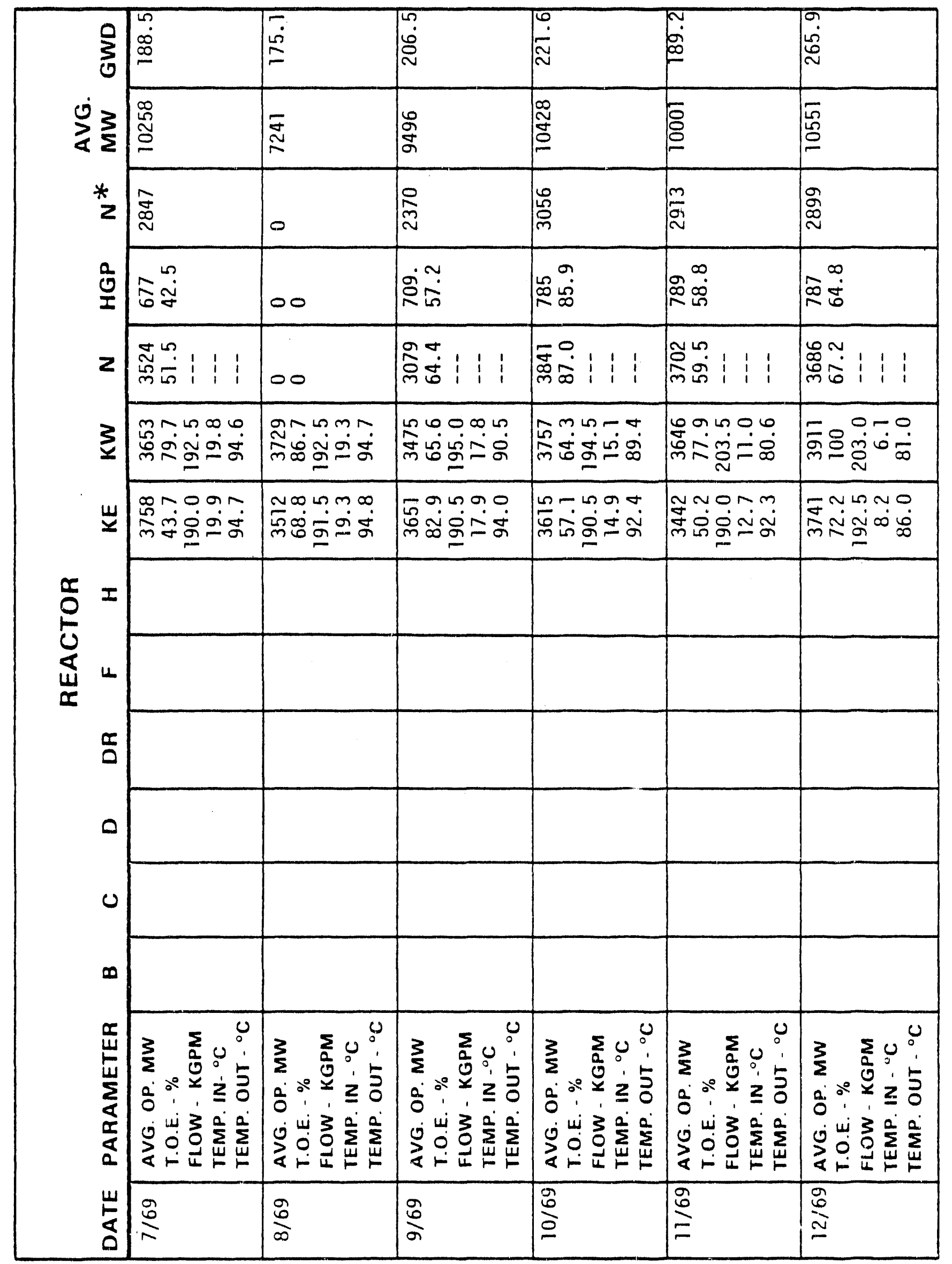




\begin{tabular}{|c|c|c|c|c|c|c|}
\hline$\sum_{0}^{\circ}$ & 家 & | & a & ए? & $\begin{array}{l}0 \\
\infty \\
0 \\
=\end{array}$ & ? \\
\hline$\sum_{<}^{0} 3$ & 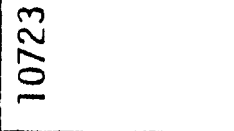 & $\underset{\tilde{E}}{\tilde{\sigma}}$ & 筁 & 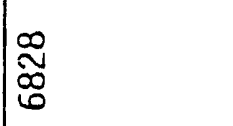 & $\frac{N}{6}$ & 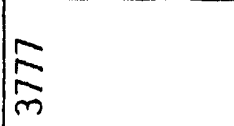 \\
\hline * & $\stackrel{m}{\infty}$ & స్ల్ & $\frac{m}{m}$ & న్ & I & $\begin{array}{llll}0 & 1 & 1 & 1\end{array}$ \\
\hline$\frac{0}{1}$ & 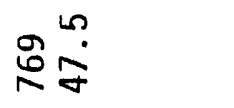 & ミ゚ & 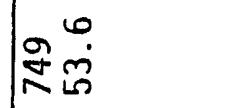 & कृ & 采安 & 00 \\
\hline$z$ & 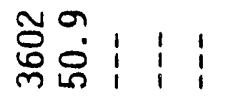 & 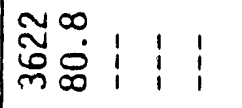 & 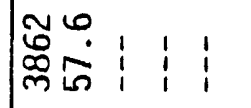 & 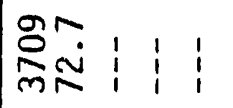 & 㖒占: & 00 \\
\hline$\frac{3}{x}$ & 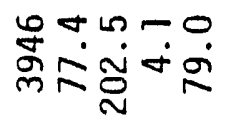 & & & & & \\
\hline$\ddot{\underline{y}}$ & 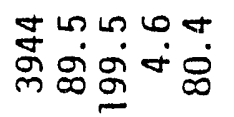 & 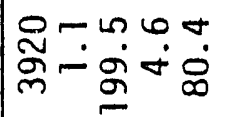 & 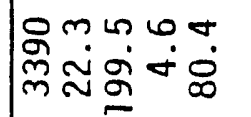 & 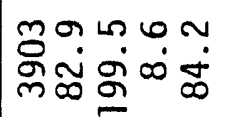 & 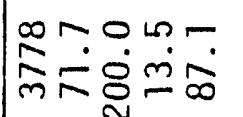 & 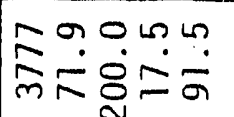 \\
\hline & & & & & & \\
\hline$\underset{\mathbb{2}}{\mathbb{\alpha}}$ & & & & & & \\
\hline$\stackrel{\pi}{0}$ & & & & & & \\
\hline 0 & & & & & & \\
\hline$u$ & & & & & & \\
\hline$\infty$ & & & & & & \\
\hline 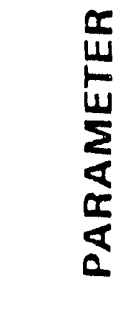 & 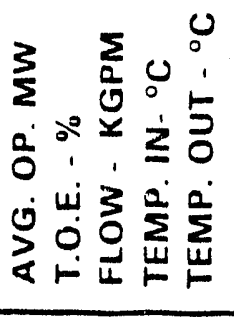 & 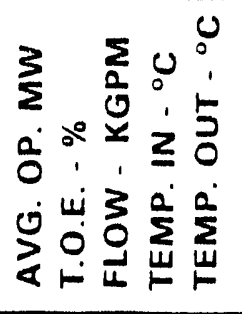 & 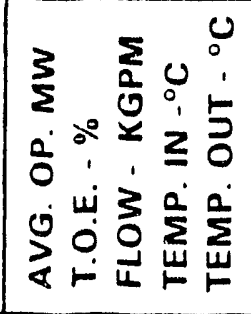 & 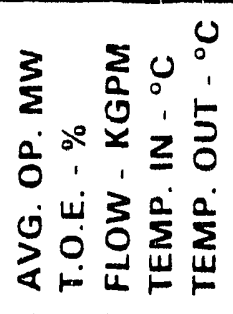 & 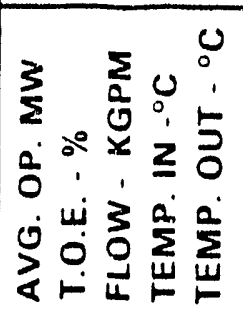 & 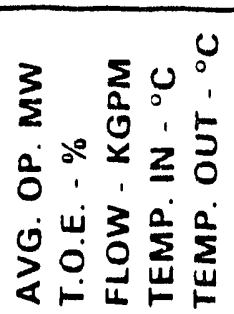 \\
\hline 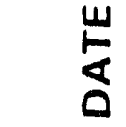 & $\stackrel{?}{\Sigma}$ & $\frac{શ}{i}$ & $\frac{\rho}{m}$ & $\stackrel{2}{\xi}$ & $\frac{8}{n}$ & $\frac{2}{6}$ \\
\hline
\end{tabular}




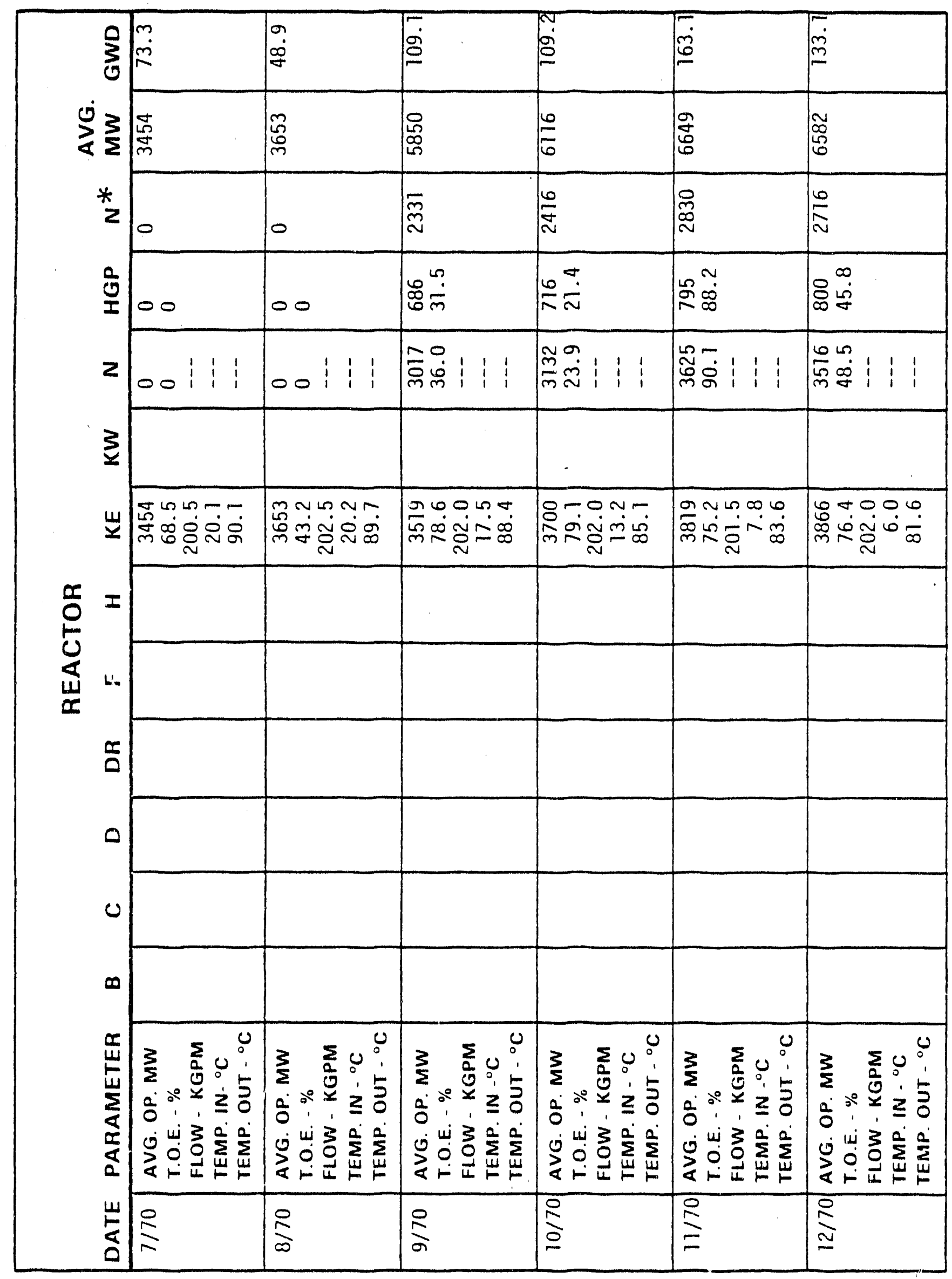




\begin{tabular}{|c|c|c|c|c|c|c|}
\hline$\sum_{0}^{0}$ & 守 & & $\cong$ & 家 & 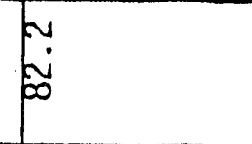 & $\mid \begin{array}{l}0 \\
\dot{8}\end{array}$ \\
\hline$\sum_{<}^{ن} 3$ & $\frac{\pi}{6}$ & & $\stackrel{\mathbb{N}}{\mathbf{N}}$ & I & m & 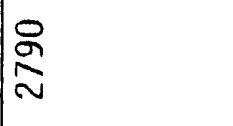 \\
\hline$\stackrel{*}{z}$ & $\stackrel{\infty}{\curvearrowright}$ & & N & 胥 & m & $\stackrel{\curvearrowright}{\curvearrowright}$ \\
\hline$\frac{0}{0}$ & $\bar{\infty}$ & & & $\stackrel{\infty}{\infty}_{\infty}^{\infty}$ & 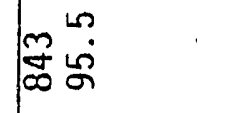 & 象官 \\
\hline$z$ & 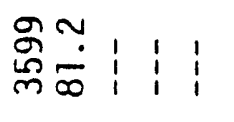 & & \begin{tabular}{|l|l|l}
$\mathbb{N}^{2}$ & & 1 \\
& 1 & 1
\end{tabular} & |ू̊日: & 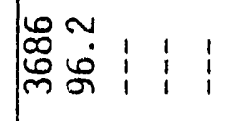 & 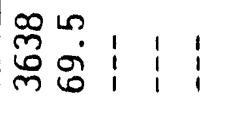 \\
\hline 3 & & $E$ & & & & \\
\hline$\ddot{\underline{x}}$ & 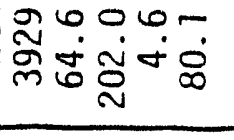 & $\stackrel{\Perp}{5}$ & & & & \\
\hline$\stackrel{x}{0}^{\frac{\pi}{1}}=$ & & $\frac{0}{\sigma}$ & & & & \\
\hline$\underset{\varpi}{\mathbb{\varpi}} 4$ & & 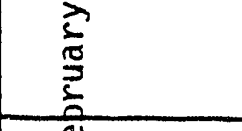 & & & & \\
\hline$\stackrel{\pi}{\Delta}$ & & $\begin{array}{l}L \\
E \\
E \\
\end{array}$ & & & & \\
\hline 0 & & 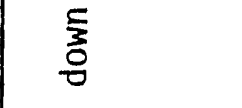 & & & & \\
\hline$u$ & & $\begin{array}{l}\frac{\pi}{3} \\
\vdots \\
0 \\
\end{array}$ & & & & \\
\hline$\infty$ & & $\begin{array}{l}\frac{\pi}{\mathbb{J}} \\
\propto \\
z\end{array}$ & & & & \\
\hline 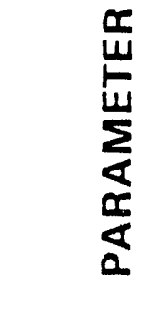 & 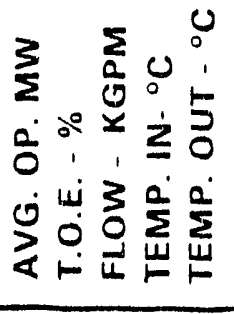 & 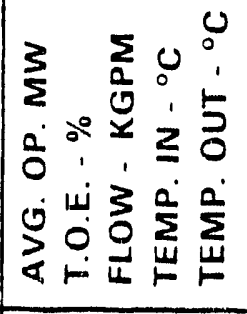 & 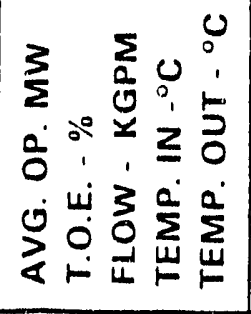 & 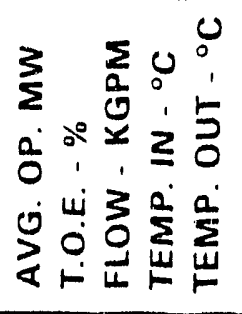 & 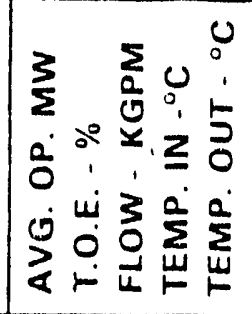 & 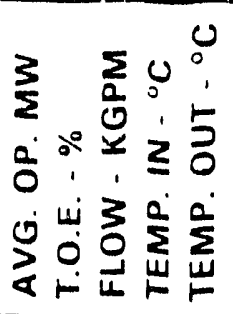 \\
\hline 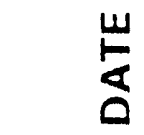 & $\equiv$ & $\underset{\text { i }}{i}$ & $\lesssim$ & $\frac{\Sigma}{\infty}$ & $\frac{\Sigma}{\sigma}$ & 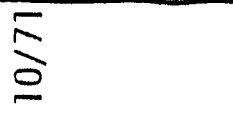 \\
\hline
\end{tabular}




\begin{tabular}{|c|c|c|c|c|c|c|}
\hline$\sum_{0}^{0}$ & $\stackrel{0}{\stackrel{0}{\Sigma}}$ & $\&$ & & & & \\
\hline 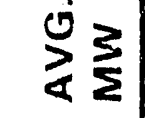 & 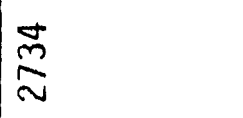 & 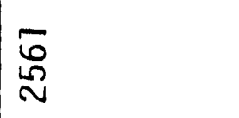 & & & & \\
\hline * & 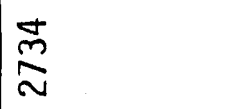 & চ్ర & & & & \\
\hline$\frac{0}{0}$ & $\underset{\infty}{\infty} \stackrel{\infty}{\infty}$ & 象官 & & & & \\
\hline$z$ & 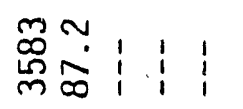 & 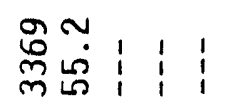 & & & & \\
\hline 3 & & & & & & \\
\hline$\ddot{\underline{y}}$ & & & & & & \\
\hline$\overbrace{}^{\frac{\pi}{0}} I$ & & & & & & \\
\hline$\underset{\widetilde{L}}{\mathbb{\leftarrow}} 4$ & & & & & & \\
\hline$\frac{\alpha}{0}$ & & & & & & \\
\hline 0 & & & & & & \\
\hline 0 & & & & & & \\
\hline$\infty$ & & & & & & \\
\hline 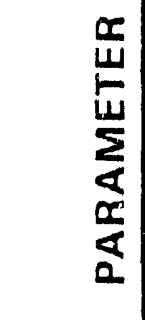 & 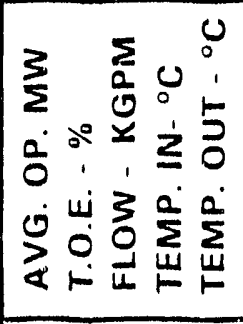 & 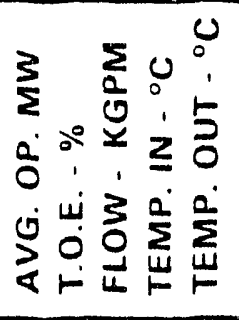 & 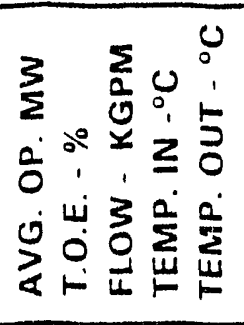 & 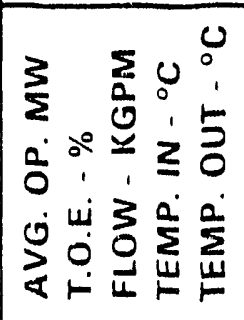 & 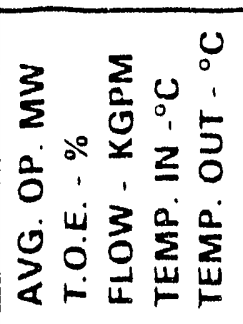 & 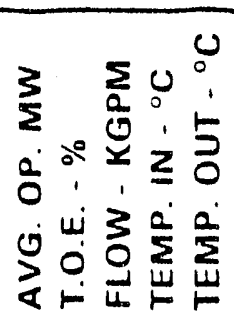 \\
\hline$\frac{\omega}{\stackrel{L}{\Delta}}$ & $\Xi$ & $\underset{\Sigma}{\Sigma}$ & & & & \\
\hline
\end{tabular}




\section{APPENDIX B}

COMPARISONS OF COLUMBIA RIVER HEAT GAIN WITH REACTOR ADDITIONS 


\begin{tabular}{|c|c|c|c|c|c|c|c|}
\hline UATE & $\begin{array}{c}\text { FEIEST RAFIOS } \\
\text { TEMFERATURE } \\
\text { COEG. CO }\end{array}$ & $\begin{array}{l}\text { EILHLANO } \\
\text { TEMFEFHTUEE } \\
\text { COEG. CO }\end{array}$ & $\begin{array}{l}\text { TEMF. } \\
\text { OIFF. } \\
\text { UEEQ. C }\end{array}$ & $\begin{array}{l}\text { RIUER } \\
\text { FLOWU } \\
\text { GKLFS: }\end{array}$ & $\begin{array}{l}\text { EOMFUTEO } \\
\text { HEFT } \\
\text { CHLU: }\end{array}$ & $\begin{array}{l}\text { FERCTOF } \\
\text { HEHT } \\
\text { GWW }\end{array}$ & $\begin{array}{l}\text { HEFT } \\
\text { UIFF. } \\
\text { WWW }\end{array}$ \\
\hline---- & 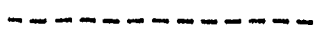 & - - - - & $---\cdots$ & $--\cdots--$ & $---m-n-n$ & $----\cdots$ & $-\infty-\infty$ \\
\hline E E & 12.84 & $1 \Sigma .8 z$ & 日. 93 & 508.90 & 45516 & 1602 & 28gas. \\
\hline$\vec{P} \in 4$ & 15. 20 & 1E. 51 & 1.21 & 295.81 & 42348 & 1E1E1. & 20197. \\
\hline $8, E 4$ & 17.08 & 18. 89 & 1. 82 & 131.14 & 28324 & 15740 & 1250ี. \\
\hline 964 & 16. 22 & $18.4 E$ & 2. 14 & 74.32 & 18076. & 16510 & 2डeE. \\
\hline 10,64 & 14.55 & 15. 75 & 1. 20 & 87. 11 & 12354 & 12697 & $-7+2$ \\
\hline 1104 & 10. 80 & 12. 24 & 1. 44 & 70.12 & 11927. & 17896. & -5952 \\
\hline $12, E 4$ & E. 25 & 7.82 & 1. 57 & 88.48 & 12723 & 19490. & - \\
\hline $1, E 5$ & 4. 4.5 & E. 10 & 1. 55 & 87.37 & 15173 & 18519 & - $1 E 4 E$. \\
\hline $\begin{array}{l}\text { BE } \\
3 \in 5\end{array}$ & 2.33 & 5.35 & 2.03 & $99 \cdot 24$ & $2389 ?$ & 16952 & 6904 \\
\hline $4=5$ & E. 65 & $\begin{array}{l}\text { G. } \\
9.99\end{array}$ & $\begin{array}{l}2.15 \\
\text { 2. } 44\end{array}$ & $\begin{array}{r}83.33 \\
111.81\end{array}$ & $\begin{array}{l}22553 . \\
32276 .\end{array}$ & $\begin{array}{l}15413 . \\
16420 .\end{array}$ & $\begin{array}{r}146 . \\
15946 .\end{array}$ \\
\hline 5.5 & 18. 11 & 11. 92 & 1. 02 & 235.29 & 20524 & $1527 \%$ & 12247 \\
\hline$E: E$ & 12.25 & 14.22 & 0.87 & 313,50 & $221=2$ & $145+2$ & 17559 \\
\hline 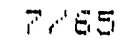 & 16.05 & 17.28 & 1. 23 & 218.42 & 31727. & $1 \Xi \Xi 2 \Xi$ & 19464 \\
\hline $8, E 5$ & 1E. $3 E$ & 19.83 & 1. $4 \overrightarrow{7}$ & 127.P7 & 22221 & 1202. & 969 \\
\hline 965 & 17.31 & 18.53 & 1. 23 & 77.23 & 11225 & 12096. & -1365. \\
\hline 10.65 & 15. 28 & 1E. 41 & 1. 11 & 53.78 & 3411 & 12842 & $-44 \geq 1$ \\
\hline 11:E5 & 11.87 & 12. 56 & ㄴ. 59 & 7日. & $5>74$ & 12447 & $-E B D$ \\
\hline 12,65 & 7. 79 & 3. 44 & 日. 85 & 74.15 & 5698. & $1 \Xi 7 \bullet 1$. & -805 \\
\hline 1 1 E E & 4. 84 & 5.92 & 1. 08 & B. 91 & 6557 & 13546 & -4991 \\
\hline ZUE & $4: 14$ & 5. 25 & 2. 11 & 89.39 & 20073. & $148=a$. & $5 \geq 91$ \\
\hline$\sum E E$ & 4.45 & E. 86 & 2.35 & 78.70 & 21315 & $1 E 416$. & 4895 \\
\hline AUE & 7. $8 Z$ & 16. 21 & 2. 48 & $75.8 \theta$ & 22330 & 14163 & G1E \\
\hline$E_{H} \in E$ & 10.59 & 12.05 & 1. 45 & 182.58 & 31547. & 12200 & $1924 \bar{r}$ \\
\hline EAE & 12. 43 & 13.47 & 1. 04 & 278.33 & $3+163$ & 12247 & 21916 \\
\hline PREE & 15.28 & 1E. 19 & 0. 80 & 229.39 & 23937. & 3519 & 20119 \\
\hline EUE & 17.55 & 1E. 77 & 1. 22 & 108.65 & 15746 & S17? & 12502 \\
\hline$G E E$ & 17.48 & $13.3 E$ & 1.88 & 72.94 & $162+3$ & 14473 & DFPE. \\
\hline $1 G B E$ & 14. 62 & 15.52 & 1. 010 & 86.74 & 7308 & 11455 & -2547 \\
\hline $11, E \in$ & 11. E2 & 12. 57 & 1. 94 & 65.58 & 7295. & 12033 & -6525. \\
\hline $12, E E$ & 5.27 & 9. 49 & 1. 12 & 73.71 & 9777. & 15052 & -5275. \\
\hline
\end{tabular}

\begin{tabular}{|c|c|c|c|c|c|c|c|}
\hline DATE & $\begin{array}{c}\text { FRIEST FIAFIDE } \\
\text { TEMFERATUFE } \\
\text { CDEG. D? }\end{array}$ & $\begin{array}{l}\text { RIEHLAND } \\
\text { TEMPEFATUEE } \\
\text { CDEG. C? }\end{array}$ & $\begin{array}{l}\text { TENF. } \\
\text { OIFF. } \\
\text { OEII. C }\end{array}$ & $\begin{array}{l}\text { RIWEF } \\
\text { FLOWW } \\
\text { SKEFS }\end{array}$ & $\begin{array}{l}\text { QDMFUTED } \\
\text { HEAT } \\
\text { SMAD? }\end{array}$ & $\begin{array}{l}\text { FEALTDF: } \\
\text { HEAT } \\
\text { GMLS }\end{array}$ & $\begin{array}{l}\text { HEFT } \\
\text { DIFF. } \\
\text { GMH }\end{array}$ \\
\hline$\cdots$ & --ー-ー-ー-ー- & $---n-m-n$ & ---- & $--\cdots--$ & $--n-n--$ & $--\cdots--$ & $\ldots \ldots$ \\
\hline $1, E$ & 5.92 & 7. $2 E$ & 1. 44 & 75.25 & 12058 & 15116 & -225 \\
\hline $2 \cdot \theta \overrightarrow{0}$ & 5.25 & 8.59 & 1. 74 & PE:EZ & 15793. & 15107. & ESE. \\
\hline$Z E F$ & 4. 99 & 8.54 & 1. 85 & 90.22 & $17 E 78$. & 12475 & 4201 \\
\hline $4 E$ & E. 31 & $\theta .80$ & 200 & 89.22 & 21169 & 15923 & 5180. \\
\hline$E, \because \in$ & 10. 85 & 12.93 & 1.90 & 128.60 & 32479 & 12722 & 19745. \\
\hline$E, E$ & 12. 27 & 12.89 & B. 1 & 420.36 & 31164. & 14539 & 10574. \\
\hline 78 & 2E. 可 & 17.618 & 9.93 & 280. 91 & 31596 & 12639 & 18957 \\
\hline
\end{tabular}




\begin{tabular}{|c|c|c|c|c|c|c|c|}
\hline$\varepsilon, \bar{r}$ & $1 \pm .55$ & 28,22 & 1. $E T$ & 125.96 & 24703 & 12209 & 11274 \\
\hline $9, \bar{R}$ & 18. 20 & 19.39 & 1.19 & 8日. 85 & 11432 & ज十 & 2Zة \\
\hline 1E, & 15.42 & 18.95 & 0. 53 & 71.94 & 5390. & 9290. & - 2960. \\
\hline DLEF & 11. 24 & 11.98 & 0. 82 & 74.24 & 5463. & 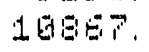 & -5354 \\
\hline 12,6 & $P .17$ & P. 83 & B. 65 & 80.82 & 6945. & $165>1$ & $-3 E 2 \theta$. \\
\hline $1, E 8$ & 4. $E 5$ & 5. E & 1. 92 & 77.89 & 9378. & 16550. & -1212 \\
\hline a & Z. $Z$ & 5. 60 & 1. $E T$ & アアプ & 14594. & 12014 & 2Бも母. \\
\hline ZUS & 4. EI & 5.65 & 1. 42 & 168.29 & 10189. & 11822 & EEE. \\
\hline A,ES & 7.99 & 6. 83 & 1. 74 & 1日日， 目 & 20032 & 10937 & 960. \\
\hline $5, E 8$ & 11. 65 & 12.84 & 1. 78 & $125.7 \mathrm{~g}$ & 2852. & 10423 & AELEG. \\
\hline$E \in E$ & 12.44 & 14. 26 & 9. 92 & 271.39 & 26258. & 9592 & 17EE \\
\hline$P \in \varepsilon$ & 1E. B & 16.99 & ‥ 93 & 220.35 & 24832. & B日a1. & 17951. \\
\hline$\varepsilon, E \Omega$ & $1 \vec{P} \cdot 51$ & 16.75 & 1. 24 & 112.52 & 15517. & 8801. & PESE. \\
\hline$\Phi, E$ & $17.1 E$ & 1日. 30 & 1. 14 & 96.86 & 12242 & 9920. & 232 \\
\hline $10, E \mathrm{E}$ & 14.25 & 14.95 & 日. 71 & 78.97 & E473. & 16519 & $-464 E$. \\
\hline 11,EE & 10.85 & 11.40 & B. 55 & 78.67 & 5128. & 18353 & -5225. \\
\hline 12RES & E. $\overrightarrow{7}$ & 7.25 & 0.59 & 91.65 & $E 44 ?$. & 9652 & -3465. \\
\hline $1, E 9$ & 2. 45 & 2.71 & 6. 20 & 104,49 & $32>5$. & 9091. & -5801. \\
\hline $2 B E$ & 1. $4 E$ & 1. 90 & B. 44 & 118.81 & $\$ 185$. & 9248. & -3963 \\
\hline$Z \in G$ & 3. 29 & 4.34 & B. 95 & 185. P & 11886. & 9265. & $2 \in \geq 1$. \\
\hline 489 & 7. 21 & $\overrightarrow{7} .97$ & B. $>E$ & 185.33 & $16>04$. & 9263. & 7501. \\
\hline 5,9 & 10. 80 & 11. 44 & ด. 83 & 234,71 & 17580. & EIPT. & 11260. \\
\hline 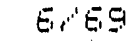 & 14.61 & 15. 32 & 日. 71 & 221.17 & 20025. & 8227. & 11680 \\
\hline
\end{tabular}

\begin{tabular}{|c|c|c|c|c|c|c|c|}
\hline CIATE & $\begin{array}{c}\text { FRIEST RHFIDS } \\
\text { TEMFERATUIRE } \\
\text { UCEG. CO }\end{array}$ & $\begin{array}{l}\text { RICHLANO } \\
\text { TEMFERATUEE } \\
\text { UEEG. C }\end{array}$ & $\begin{array}{l}\text { TEMP. } \\
\text { DIFF. } \\
\text { OEEL. D } \\
\text { DE- }\end{array}$ & 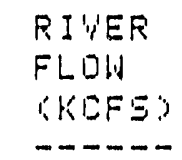 & $\begin{array}{c}\text { DOMPUTED } \\
\text { HEAT } \\
\text { SMHU }\end{array}$ & $\begin{array}{l}\text { F.EACTOF: } \\
\text { HEAT } \\
\text { GWW }\end{array}$ & $\begin{array}{l}\text { HEFT } \\
\text { DIFF. } \\
\text { GWW }\end{array}$ \\
\hline$\vec{P} \theta \mathrm{G}$ & 17.11 & 17. 87 & 0. 75 & 189.90 & $1>131$ & 8081 & 11550. \\
\hline $8, \theta 9$ & 18. 20 & 19. 20 & 1. Bis & 161.95 & 12650 & SEA. & 7916 \\
\hline 9,69 & $17 \cdot 78$ & 16.80 & 0. 91 & 75.94 & 8159 & 8882. & IZPE. \\
\hline 1BRES & 14. 81 & 15. 15 & 6. 34 & 82.46 & 3341 & 7149 & - $398 \mathrm{~F}$ \\
\hline $11, E 9$ & 11. 55 & 11. 72 & ‥ 17 & 88.68 & 1780. & E397. & -4521. \\
\hline 12RES & $\vec{P} \cdot E 4$ & 0.92 & 0.38 & 95.91 & 4409. & 8577. & -4163 \\
\hline 187 & 4. 27 & 5. 27 & 1. 96 & B. 21 & 10234. & 8652. & 20气。 \\
\hline 278 & 4. 14 & 4.85 & ㅈ. 72 & 77. 日2 & 5584 & 2293 & 4231 \\
\hline 578 & 4. 75 & 5.72 & 0.90 & 85. 75 & ヨРอี. & 2577. & 7191. \\
\hline $4: 70$ & E. 85 & 7.94 & 1. 09 & 31.91 & 11908. & 5302. & 6525 \\
\hline $5 \times 70$ & 10.87 & 11. 72 & B. 85 & 131.10 & 13131. & 3806. & 9ะลБ. \\
\hline EVG & 14.93 & 15. 39 & 国. 50 & 163.12 & 12223. & 2717 & 9586. \\
\hline 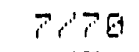 & 1E. 44 & 19. 62 & 日. 39 & 124.68 & 14574. & $2 \geq E 5$. & 12206. \\
\hline 8770 & 19. 24 & 19.94 & ㅂ. 79 & 18日. 79 & S3E1. & 1577. & ETE4 \\
\hline 970 & 17.49 & 17.51 & 0.02 & 75.32 & 280. & 3635. & -3429. \\
\hline $18 \%$ & 15. 17 & 14. 97 & -1.31 & 74.50 & -2709 & 3523 & -6222 \\
\hline $11 \% 70$ & 10. $5 E$ & 1日. 50 & 6. 90 & 74.75 & 日. & 5437. & $-54 \geq 7$ \\
\hline 12170 & ت. 15 & 5.95 & -8.21 & 78.57 & -1952 & 4294. & $-624 E$. \\
\hline 171 & 4. 61 & 4.25 & 0. 24 & 71.38 & 2019 & 4829. & $-2 \theta 10$ \\
\hline 271 & 3.55 & 2.45 & $-19.1 日$ & 95.92 & -1990. & 5182. & -625 \\
\hline 271 & 3.62 & 2.77 & B. 15 & 131.74 & 2205 & 4829. & -2504 \\
\hline $4>1$ & E. $E 1$ & 7.85 & 6. 44 & 120.71 & E24 & 4996. & 125E \\
\hline 51 & 10. 8 & 11. 15 & 0. 27 & 278.85 & 12910. & 4829 & 718 \\
\hline EP1 & 12. 12 & 12.95 & 0.23 & 290.80 & 11570. & 4998. & 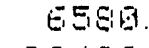 \\
\hline $7 P 1$ & 15.22 & 1E. 44 & 1. 13 & 213.36 & 28464. & 55. & 20469 \\
\hline 8171 & 18.42 & 19.54 & 1. 12 & 132.34 & 17562. & 1548. & 15954 \\
\hline 97 & $1 \vec{P} \cdot 21$ & 17.84 & 0.63 & 74.63 & 5001. & 2740. & $28 E 1$ \\
\hline $10 \times 1$ & 15. 24 & 14.96 & -28 & 71.91 & $-23 E 4$. & 1955. & -4219 \\
\hline 11.71 & 11. 20 & 16. 71 & -8.59 & 82. 32 & -5730. & 2420 & -826 \\
\hline $2=\overrightarrow{1}$ & $E . T E$ & E. 20 & -0.80 & 39.93 & -7143 & 1452. & 3505 \\
\hline
\end{tabular}




\section{DISTRIBUTION}

No. of

Copies

\section{OFFSITE}

1 DOE Office of Scientific and Techinical Information

Technical Information Center P.0. Box 62

Oak Ridge, TN 37830
No of

Copies

\section{ONSITE}

1 RL Public Reading Room

1 J.J. Fix

1 S.P. Gydesen

2 C.M. Heeb

$1 \quad$ L.D. Kannberg

1 J.P. McNeece

2 Technical Library 

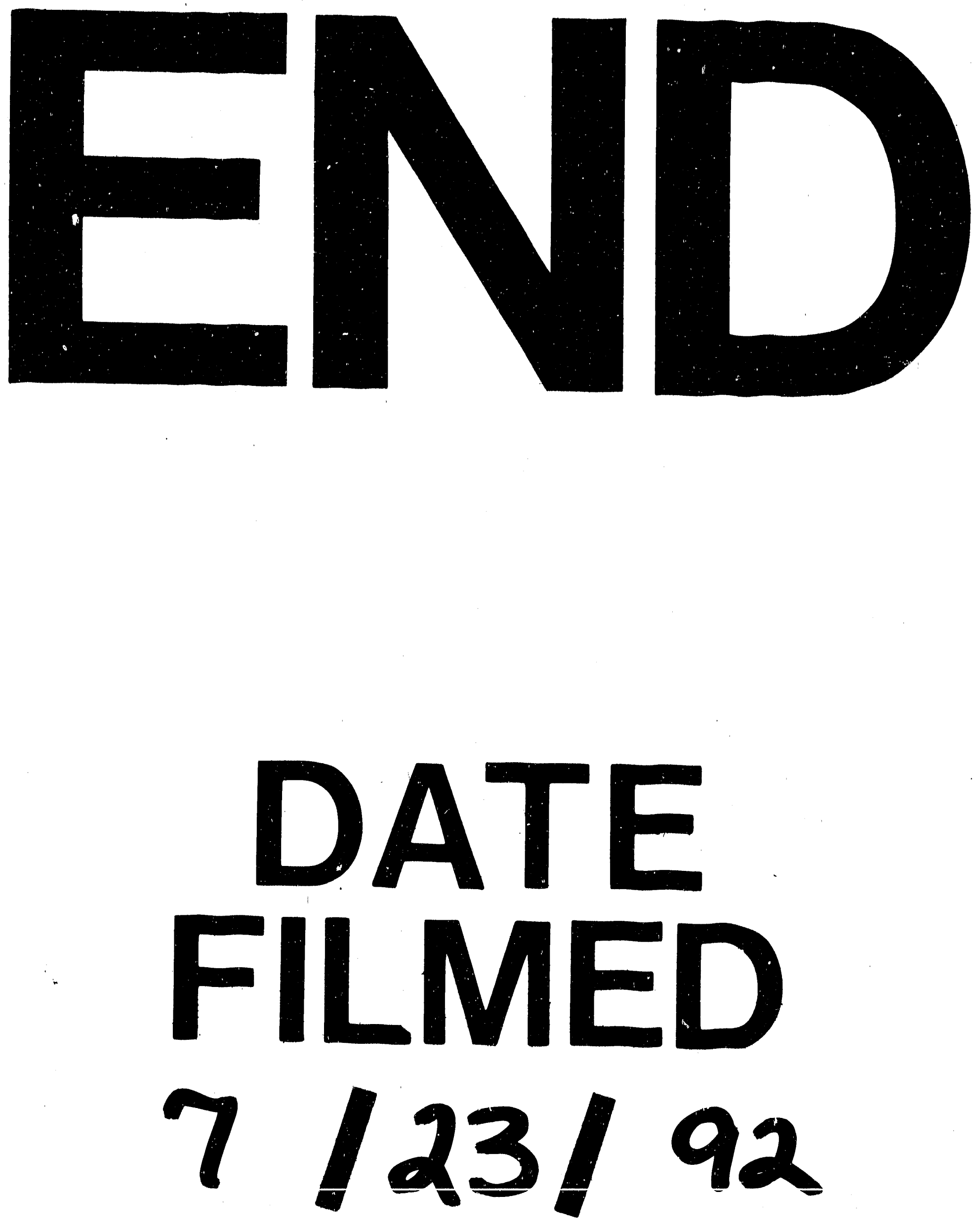
- 